\title{
Evaluation of Codisposal Viability for Aluminum-Clad DOE-Owned Spent Fuel: Phase II - Degraded Codisposal Waste. Package Internal Criticality
}

by

W. Swift

Westinghouse Savannah River Company

Savannah River Site

Aiken, South Carolina 29808

Civilian Radioactive Waste Management System NV USA

This paper was prepared in connection with work done under the above contract number with the U. S. Department of Energy. By acceptance of this paper, the publisher and/or recipient acknowledges the U.S. Government's right to retain a nonexclusive, royalty-free license in and to any copyright covering this paper, along with the right to reproduce and to authorize others to reproduce all or part of the copyrighted paper. 
This report was prepared as an account of work sponsored by an agency of the United States Government. Neither the United States Government nor any agency thereof, nor any of their employees, makes any warranty, express or implied, or assumes any legal liability or responsibility for the accuracy, completeness, or usefulness of any information, apparatus, product, or process disclosed, or represents that its use would not infringe privately owned rights. Reference herein to any specific commercial product, process, or service by trade name, trademark, manufacturer, or otherwise does not necessarily constitute or imply its endorsement, recommendation, or favoring by the United States Government or any agency thereof. The views and opinions of authors expressed herein do not necessarily state or reflect those of the United States Government or any agency thereof.

This report has been reproduced directly from the best available copy.

Available to DOE and DOE contractors from the Office of Scientific and Technical Information, P. O. Box 62, Oak Ridge, TN 37831; prices available from (423) 576-8401.

Available to the public from the National Technical Information Service, U. S. Department of Commerce, 5285. Port Royal Road, Springfield, VA 22161. 


\section{Westinghouse}

Savạnnah Rlver Company

Aiken, SC 29808

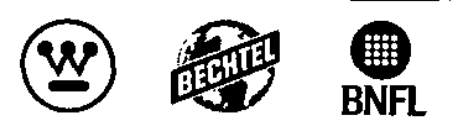

April 8, 1999

Document Number: BBA000000-01717-5705-00017 REV 01

Document Title: Evaluation of Codisposal Viability for Aluminum-Clad DOE-Owned Spent Fuel: Phase II

Degraded Codisposal Waste Package Internal Criticality

\section{DISCLAIMER:}

This Document no longer applies to Savannah River fuels due to our preferred approach to melt and dilute our fuel. 
WBS: 1.2 .1 .10

QA: L

Civilian Kadioactive Waste Management System Management \& Operating Contractor

\title{
Evaluation of Codisposal Viability for Aluminum-Clad DOE-Owned Spent Fuel: Phase II Degraded Codisposal Waste Package Internal Criticality
}

\author{
Document Identifier: BBA000000-01717-5705-00017 REV 01
}

April 2, 1998

Prepared for:

U.S. Department of Energy

Westinghouse Savannah River Co.

Savannah River Site

P.O. Box 616

Aiken, SC 29802

Prepared By:

Civilian Radioactive Waste Management System

Management \& Operating Contractor

1180 Town Center Drive

Las Vegas, NV 89134

Under Contract Number

DE-AC08-91RW00134 
Civilian Radioactive Waste Management System

Management \& Operating Contractor

\title{
Evaluation of Codisposal Viability for Aluminum-Clad DOE-Owned Spent Fuel: Phase II Degraded Codisposal Waste Package Internal Criticality
}

\author{
Document Identifier: BBA000000-01717-5705-00017 REV 01
}

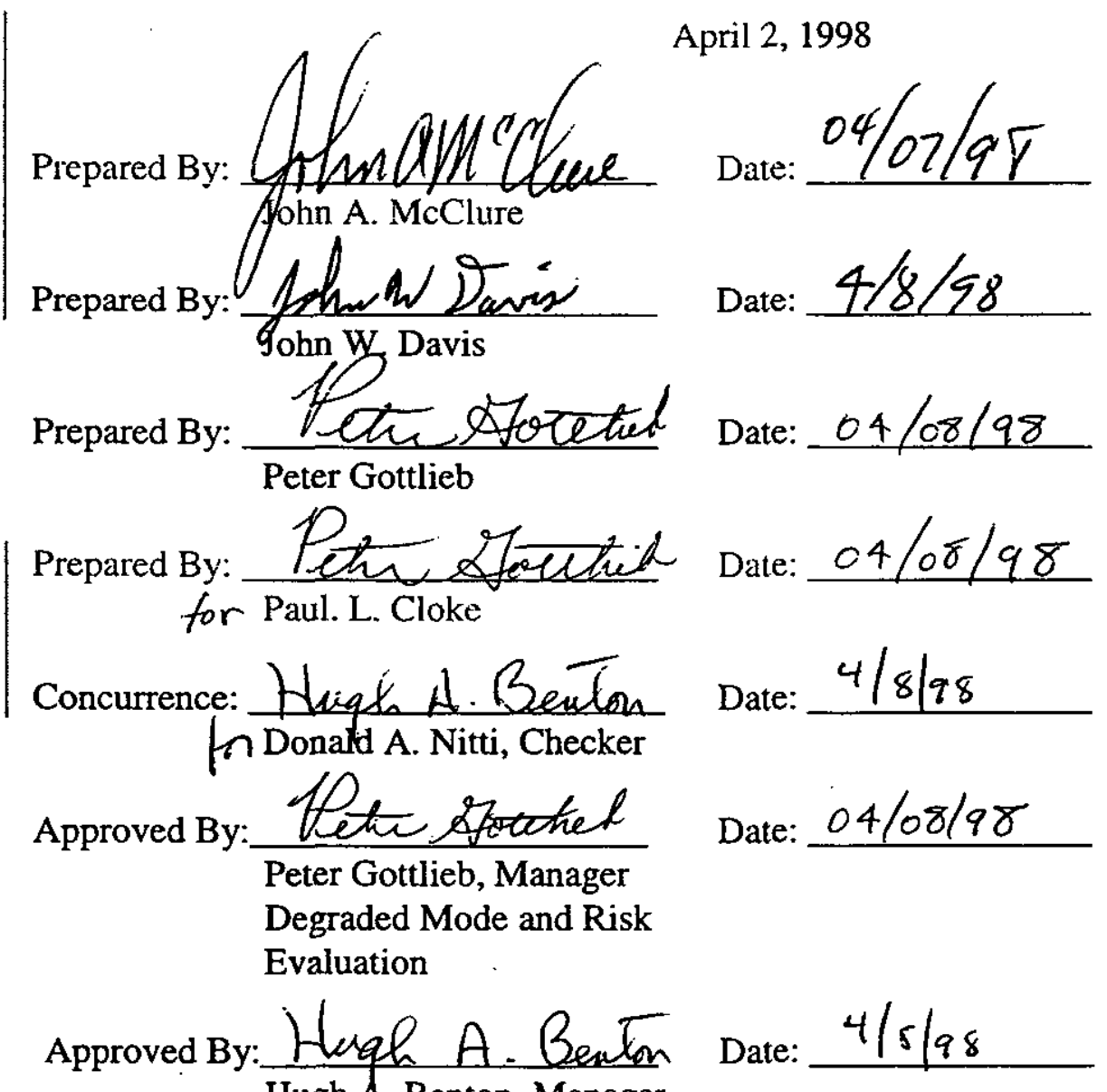




\section{HISTORY OF CHANGE PAGE}

Rev/Change Number Description and Reason for Change

REV $00 \quad$ Initial Issue

REV 01

Revisions identified with vertical line in the margin.

Revisions incorporate SRS comments and additional geochemistry analyses. Cover page revised to add authors. 


\section{Evaluation of Codisposal Viability for Aluminum-Clad DOE-Owned Spent Fuel: Phase II - Degraded Codisposal Waste Package Internal Criticality}

\section{EXECUTIVE SUMMARY}

This report presents the analysis and conclusions with respect to disposal criticality for canisters containing aluminum-based fuels from research reactors. The analysis has been divided into three phases. Phase I, dealt with breached and flooded waste packages containing relatively intact canisters and intact internal (basket) structures; Phase $\amalg$, the subject of this report, covers the degradation of the spent nuclear fuel (SNF) and structures internal to the codisposal waste package including high level waste (HLW), canisters, and criticality control material. Massachusetts Institute of Technology (MIT) uranium aluminide (U-Al) fuel with $93.5 \%$ enriched uranium and Oak Ridge Research Reactor (ORR) uranium silicide (U-Si-Al) fuel with $20.56 \%$ enriched uranium were selected by the Alternative Technology Program of the Westinghouse Savannah River Company (SRS) as being representative of the high enriched uranium (HEU) and medium enriched uranium (MEU) fuel inventories, respectively. Phase III will consider the possibility of external criticality, which can arise from a flow of water carrying fissile material out of the waste package.

The objectives of this work are:

1) to develop canister designs for codisposal of HEU and MEU SNF,

2) to show that these designs meet the regulatory requirements for emplacement in the repository, and

3) to demonstrate that the degraded configurations will meet the criticality requirements as currently understood for long-term disposal.

The first two objectives were met in the Phase I report and the third is addressed in this report.

Conceptual canister designs were developed for codisposal of HEU and MEU SNF as documented in the Phase I report. Designs with 64 MIT assemblies (16 assemblies per layer, 4 layers) or 40 ORR assemblies (10 assemblies per layer, 4 layers) were developed for these fuel types. As a result of the differences in assembly size, uranium enrichment, and uranium loading, the amount of ${ }^{235} \mathrm{U}$ per package is significantly different in the MIT and ORR canister designs with $32.9 \mathrm{~kg}$ of ${ }^{235} \mathrm{U}(35.2 \mathrm{~kg}$ of $\mathrm{U})$ and with $13.9 \mathrm{~kg}$ of ${ }^{235} \mathrm{U}(67.5 \mathrm{~kg}$ of $U)$, respectively. The nominal design for the codisposal waste package contains $5 \mathrm{HLW}$ canisters (represented by 5 Defense Waste Processing Facility (DWPF) canisters from the SRS) in a pentagonal array with the fuel canister placed in the center. For Phase I, criticality control was maintained within a $439.3 \mathrm{~mm}$ OD, $15 \mathrm{~mm}$ thick XM-19 canister shell by means of borated stainless steel plates incorporated into an internal stainless steel basket structure. This design satisfied criticality requirements with the intact basket.

Ranges of environmental parameters and failure mechanisms were evaluated to develop degradation scenarios. The chemistry/geochemistry of the system was analyzed as a function of time using the EQ3/6 program with successive runs linked to simulate water dripping into, and flowing out of, the waste package. A typical sequence of degradation would be the following:

1) water dripping on a waste package over long periods of time;

2) corrosion and eventual breach of waste package barriers allowing accumulation of water 


\section{Evaluation of Codisposal Viability for Aluminum-Clad DOE-Owned Spent Fuel: Phase II - Degraded Codisposal Waste Package Internal Criticality}

in the waste package;

3) aqueous corrosion of stainless steel HLW and fuel canisters;

4) degradation of HLW glass to form clay;

5) degradation of Al-based fuel concurrent with or after the HLW glass;

6) degradation of fuel canister basket materials including criticality control material; and

7) flushing of the solution from the waste package by dripping water, which may thereby remove neutronically significant elements such as boron, for example, from the waste package.

Parametric analyses of criticality were conducted for a range of possible configurations of degraded SNF within the waste package using the MCNP code to identify the most reactive configurations and determine the minimum amount of neutron absorber required to assure that the subcritical limit was not exceeded. These analyses focused on the use of boron (B) and gadolinium (Gd) as the internal criticality control materials since both materials are well characterized and readily available from having been used extensively in commercial systems for reactivity control. Other neutron absorbing materials such as hafnium (Hf) were not included in the analyses based on considerations of cost and neutron absorbing efficiency.

Based on currently published test data, the aluminum cladding and uranium aluminum fuel matrix is expected to degrade by oxidation within a few decades after breaching the fuel canister. If the fuel canister is penetrated while the $\mathrm{HLW}$ glass is degrading, the chemistry (primarily $\mathrm{pH}>$ 10.0 and ambient $\mathrm{CO}_{2}$ pressure) would be such that most of the uranium could dissolve and be flushed out of the waste package. Such a scenario does not produce criticality and is not examined in further detail.

The more limiting scenario results when the fuel canister is penetrated after the HLW glass has been degraded and the $\mathrm{pH}$ has returned to near neutral. The uranium is not very soluble at neutral $\mathrm{pH}$, and will remain in the canister or waste package. Three general types of configuration could result, depending on the level of degradation of the other components and on the location of the canister as it degraded within the waste package:

1) degraded (oxidized) homogenized fuel material in the intact or degraded basket within the fuel canister,

2) a layer of hydrated aluminum, uranium, and iron oxides from the degraded fuel canister above the clay formed by the degraded HLW glass, and

3) degraded products from the fuel mixed with various fractions of the degraded HLW glass.

Materials tests and the geochemistry analysis with EQ3/6 indicated that as the borated stainless steel in the basket degrades, the borides may dissolve and be carried away by the flushing action of dripping water. Gadolinium oxide or phosphate, which are relatively insoluble, are better alternatives which should be used in the absorber plates of DOE-SNF canisters. The geochemistry analysis indicated the possibility of bounding chemical conditions under which Gd oxide could become sufficiently soluble to be flushed from the waste package. Gadolinium phosphate, on the other hand, remained insoluble under all chemical conditions which could occur in the waste package. 


\section{Evaluation of Codisposal Viability for Aluminum-Clad DOE-Owned Spent Fuel: Phase II - Degraded Codisposal Waste Package Internal Criticality}

The geochemical analyses summarized above led to a set of nominal configurations which were analyzed for criticality. The criticality analysis was extended by parametric variations from the nominal configurations. For example, the volume fraction of water in the clay formed by the degraded $\mathrm{HLW}$ was varied to identify the most reactive fuel mixture considering various masses of iron oxide from the degraded canisters and basket. This optimization assured a conservative analysis of the margin to the criticality limit.

Such criticality evaluations of the most reactive degraded fuel mixture (i.e., configuration 1, homogenized fuel in the DOE SNF canister) indicate the following:

1) The intact basket configuration with degraded fuel is the most reactive configuration, requiring the largest mass of added neutron absorber to ensure subcriticality.

2) Approximately $1 \mathrm{~kg}$ of Gd is required to be distributed in the canister basket for the MIT fuel if stainless steel is used for the basket, but approximately $1.25 \mathrm{~kg}$ of $\mathrm{Gd}$ is required if carbon steel is used.

3) The configuration with a degraded basket requires less than $0.25 \mathrm{~kg}$ of Gd to ensure subcriticality if the basket is of stainless steel or only $0.10 \mathrm{~kg}$ of Gd if the basket is of carbon steel (because the corrosion of carbon steel creates more moderator excluding insoluble iron oxide than does stainless steel).

Parametric analysis of configurations 2 and 3 using the MCNP code indicates these configurations to be much less reactive than configuration 1 . In particular, only $0.2 \mathrm{~kg}$ of $\mathrm{Gd}$ is required to ensure subcriticality of the degraded MIT fuel, and no Gd is required to ensure subcriticality of the ORR fuel.

The conservatism of the evaluations in this document is stated throughout the document, as appropriate.

Based on the Phase II work documented in this report, the following design guidance is provided, superseding the criticality'design guidance provided in the Phase I report.

- The $\mathrm{k}_{\text {eff }}$ must be less than 0.95 after allowance for bias and uncertainty (ANSI/ANS-8.17) for both intact and degraded configurations.

- A dispersed insoluble neutron absorber material must be utilized in the basket unless the insoluble degradation products from the basket can be demonstrated to provide sufficient water displacement and/or neutron absorption to prevent criticality within the canister.

- Carbon steel is preferred over stainless steel for the basket material, in order to minimize the presence of chromium (which may produce acidic conditions when oxidized); carbon steel also maximizes the water displacement potential of iron oxide and increases the mixing potential of the fuel with the degraded basket and neutron absorber materials.

- The neutron absorber and the degradation products from the basket must be insoluble over the pH range of 5 to 11 .

- Gadolinium is preferred over boron, as the neutron absorber for criticality control, because it is much less soluble over the expected range of $\mathrm{pH}$ values.

- The selection of a Gd criticality control material should consider that Gd phosphate is 


\section{Evaluation of Codisposal Viability for Aluminum-Clad DOE-Owned Spent Fuel: Phase II - Degraded Codisposal Waste Package Internal Criticality}

preferred over Gd oxide because it is less soluble, particularly in the mildly acidic regime which could result from the corrosion of stainless steel.

In conclusion, this report documents the sufficiency of the proposed criticality control designs. The MIT fuel (HEU) canister design with $1.25 \mathrm{~kg}$ of $\mathrm{Gd}$ distributed throughout the carbon steel basket will reduce the probability of criticality, during the first several hundred thousand years | following emplacement, to virtually zero.

The ORR fuel (MEU) canister design which uses carbon steel for the basket structure and borated stainless steel absorber plates between layers will also reduce the probability of criticality to virtually zero. 


\section{Evaluation of Codisposal Viability for Aluminum-Clad DOE-Owned Spent Fuel: Phase II - Degraded Codisposal Waste Package Internal Criticality}

\section{Table of Contents}

Item

Page

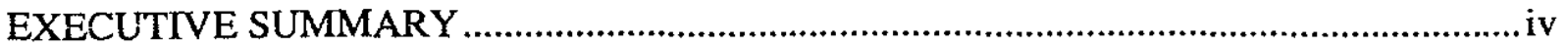

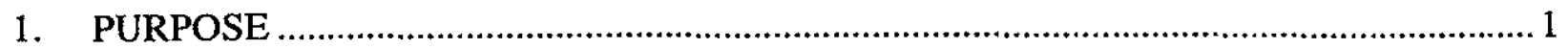

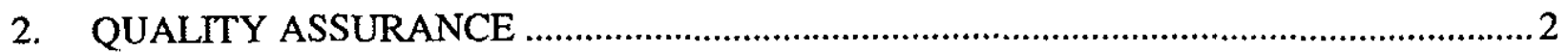

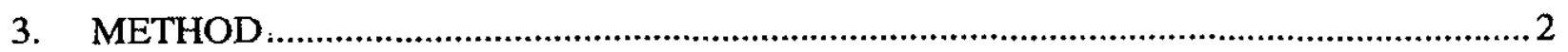

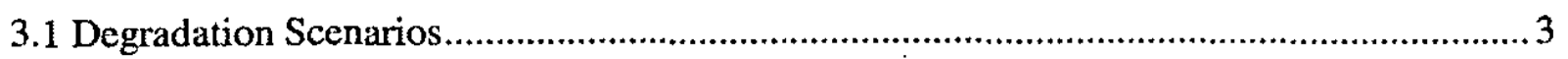

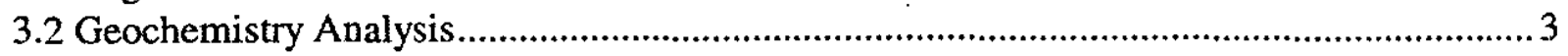

3.3 Identification of Final Configurations for Neutronics Evaluations ................................... 4

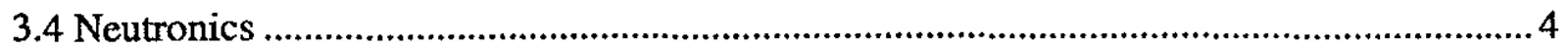

3.5 Evaluation of Probability of Occurrence of Potentially Critical Configurations ..................5

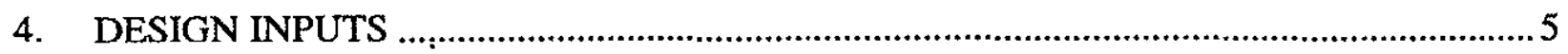

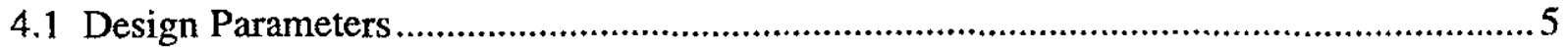

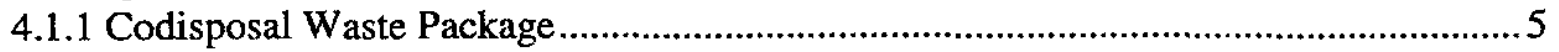

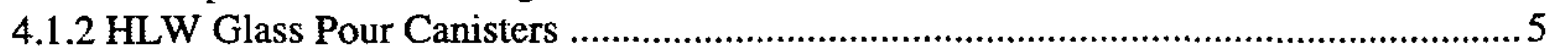

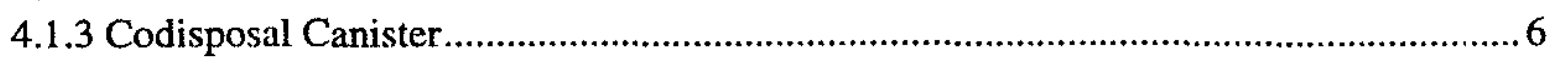

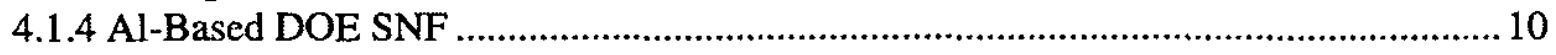

4.1.4.1 Massachusetts Institute of Technology $\mathrm{SNF}$...................................................... 10

4.1.4.2 Oak Ridge Research SNF.................................................................11

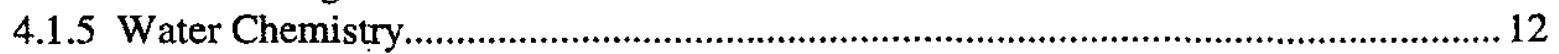

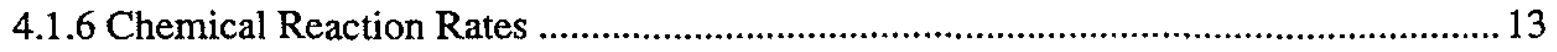

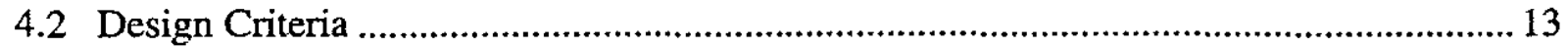

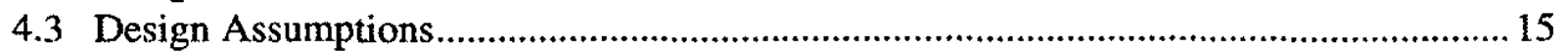

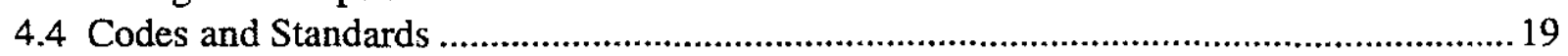

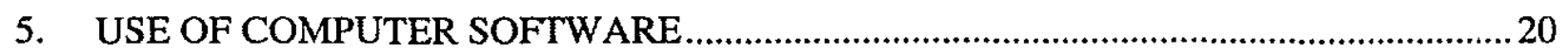

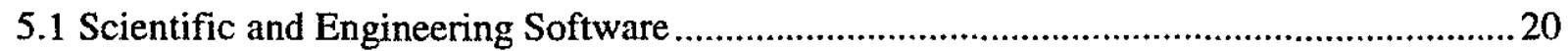

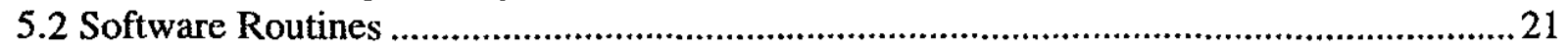

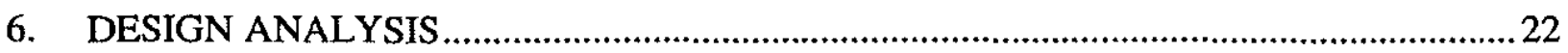

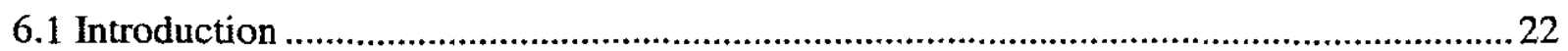

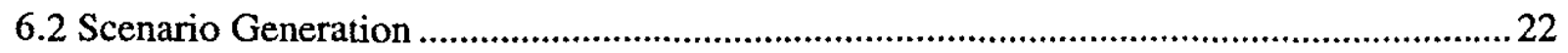

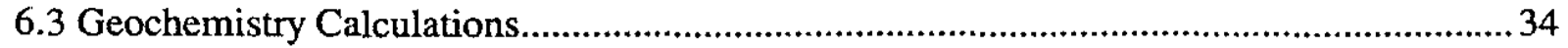

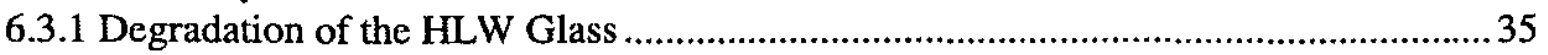

6.3.2 Degradation Products of Aluminum and Uranium Aluminide .................................. 35

6.3.2.1 SNF Degradation in a High pH Environment: Removal of Uranium and Boron . 36

6.3.2.2 SNF Degradation in a Neutral pH Environment: Removal of Gd ........................37

6.3.3 Worst Case Removal of Boron................................................................................ 37

6.3.4 Worst Case Removal of Gadolinium ..................................................................... 38

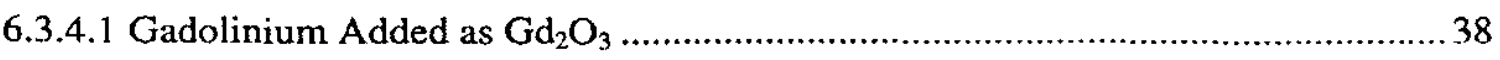

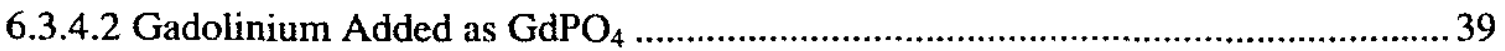




\section{Evaluation of Codisposal Viability for Aluminum-Clad DOE-Owned Spent Fuel: Phase II - Degraded Codisposal Waste Package Internal Criticality}

6.3.5 Degradation Products of Uranium Silicide 40

6.3.6 Summary of Geochemistry Results for Borated Stainless Steel Neutron Absorber.... 40

6.3.7 Summary of Geochemistry Results for Gd Neutron Absorber and Recommended Materials

6.4 Configurations Having Separation Between Uranium and the Neutron Absorber ............42

6.4.1 Separation Mechanisms................................................................................... 43

6.4.2 Evaluation of Differential Settling of Solid Particles of Different Densities...............44

6.4.3 Worst Case Separation of the Neutron Absorber Boron from Uranium ......................45

6.4.4 Separation of Gadolinium Absorber from Uranium..............................................46

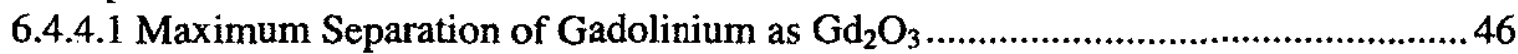

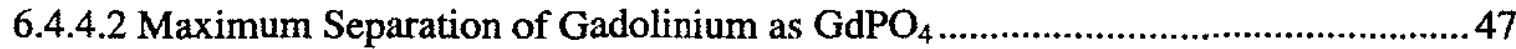

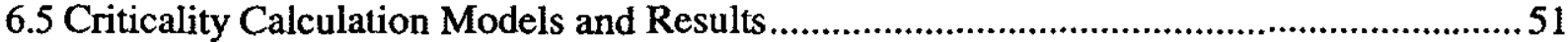

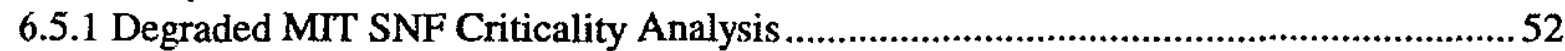

6.5.1.1 Homogeneous Mixture of Degraded MIT SNF in DOE SNF Canister.................52

6.5.1.2 Degraded MIT SNF on Top of Degraded HLW ................................................58

6.5.1.3 Degraded MIT SNF Mixed With Degraded HLW ..........................................61

6.5.2 Degraded ORR SNF Criticality Analysis..........................................................63

6.5.2.1 Homogeneous Mixture of Degraded ORR SNF in DOE SNF Canister................63 63

6.5.2.2 Degraded ORR SNF on Top of Degraded HLW ...............................................64

6.5.2.3 Degraded ORR SNF Mixed With Degraded HLW ..............................................64

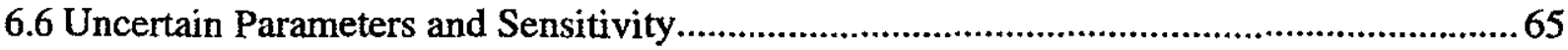

6.7 Probability of Criticality: Comparison of Alternatives ..................................................67

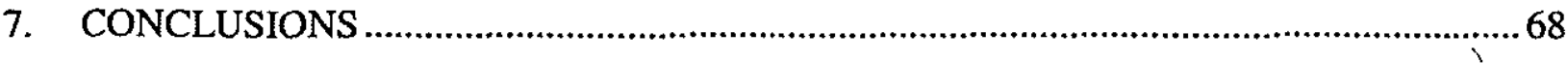

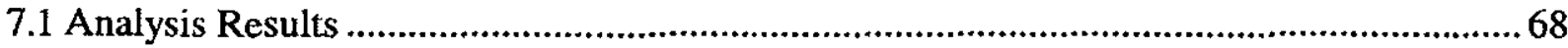

7.2 Guidance for the Codisposal Canister Design........................................................... 70

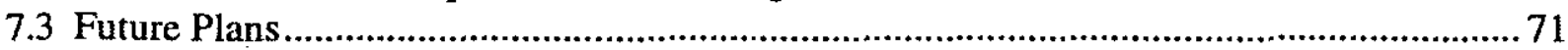

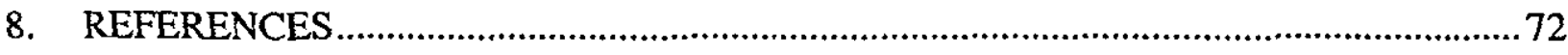




\section{Evaluation of Codisposal Viability for Aluminum-Clad DOE-Owned Spent Fuel: Phase II - Degraded Codisposal Waste Package Internal Criticality}

\section{Figures}

Figure 4.1-1. Codisposal Waste Package Assembly

Figure 4.1-2. Longitudinal Cross-Sectional View of the Codisposal Waste Package ................... 7

Figure 4.1-3. MrT SNF Canister Radial Cross-Sectional View .................................................8

Figure 4.1-4. ORR SNF Canister Radial Cross-Sectional View ..............................................9

Figure 6.2-1. Internal Degradation Scenarios for Al-Clad DOE SNF.....................................24

Figure 6.2-2. Cross Section of Waste Package Showing the DOE SNF Canister in the Center

Surrounded by HLW Canisters

Figure 6.2-3a. Early Stage of Degradation; No Holes in the Bottom; Some Ponding Water; No

Penetration of the DOE SNF Canister; Most of the HLW Canister Degraded . 26

Figure 6.2-3b. Alternative Early Stage of Degradation; Hole in the Bottom Which Drains Water

and Some of the Clay; No Penetration of the DOE SNF Canister 27

Figure 6.2-4. HLW Glass Completely Degraded; But Some of the HLW Canister Steel Shells Intact and Supporting the Still-Intact DOE SNF Canister.

Figure 6.2-5. Further Degradation Following Figure 6.2-4 Configuration; All Steel Shells have

Broken, But some Fragments Remain Uncorroded; DOE SNF Canister Breached and Basket

Degraded

.29

Figure 6.2 6. Further Degradation Following Figure 6.2-5 Configuration; All Canister Contents

and Shells have Completely Degraded.

Figure 6.2-7. Further Degradation Following Figure 6.2-4 Configuration; DOE SNF Canister

Mostly Degraded but Still Supported on the Steel Shells of HLW Canisters; Holes in the

Bottom have Drained Some Clay.

Figure 6.2-8. Further Degradation Following Figure 6.2-7 Configuration; All Canister Contents

and Shells have Completely Degraded

Figure 6.2-9. Extreme Stratification within the DOE SNF Canister: $78 \%$ of ${ }^{235} \mathrm{U}$ in Lower Layer

and $22 \%$ in Upper Layer.

Figure 6.5-1. Degraded MIT SNF in an Intact Basket .......................................................... 54

Figure 6.5-2. Homogeneous Mixture of Degraded DOE SNF and Degraded Basket in a DOE

SNF Canister

Figure 6.5-3. Degraded MIT SNF on Top of Degraded HLW ............................................59

Figure 6.5-4. Degraded MIT SNF Mixed With Degraded HLW 


\title{
Evaluation of Codisposal Viability for Aluminum-Clad DOE-Owned Spent Fuel: Phase II - Degraded Codisposal Waste Package Internal Criticality
}

\author{
Tables
}

Table 4.1.5-1. Analyzed Composition of J-13 Well Water ${ }^{1}$..................................................... 12

Table 4.i.6-i. Aqueous Corrosion Rates for Waste Package Materials ................................... 13

Table 6.3-1. Typical Corrosion Periods/Lifetimes of Materials which Affect Criticality............ 34

Table 6.3-2. Selected Time History for Simultaneous Degradation of SNF and HLW (Initially

High pH Environment).

Table 6.3-3. Selected Time History of Boron Concentration in a Codisposal Waste Package

Relying on Borated Stainless Steel for Criticality Control.................................................. 38

Table 6.3-4. Summary of Geochemistry Results for DOE SNF Canister Using Borated Stainless

Steel Absorber. 40

Table 6.3-5. Summary of Geochemistry Results for DOE SNF Canister: Removal of Gd

Absorber....

Table 6.4-1a. Cutout Statistics for a $19 \times 75$ Grid (to model carbon steel)

Table 6.4-1b. Cutout Statistics for a $190 \times 750$ Grid (to model stainless steel).

Table 6.4-2. Worst Case (Maximum Cutout) Maximum U which can Settle to the Bottom and

Minimum Gd which will Settle to the Bottom

Table 6.5.1.1-1. Degraded MIT SNF in an Intact Stainless Steel Basket with Gd Absorber.......52

Table 6.5.1.1-2. Check Cases - Carbon Steel Substitution for Stainless Steel in an Intact Basket

Table 6.5.1.1-3. Degraded MIT SNF Homogenized with Iron Oxide and Gd ............................56

Table 6.5.1.1-4. Check Cases - Degraded MIT SNF Homogenized with Iron Oxide and Gd ..... 57

Table 6.5.1.1-5. Degraded MIT SNF and Undegraded Basket Pieces Homogenized and Sett led

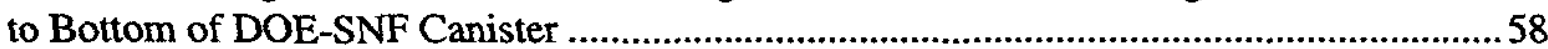

Table 6.5.1.2-1. Stratified Layers with Degraded MIT Fuel on Top...........................................58

Table 6.5.1.2-2. Stratified Layers with Degraded MIT Fuel on Top with Different $\mathrm{Fe}_{2} \mathrm{O}_{3}$ and Gd

Loadings

Table 6.5.1.3-1. Clay Mixed With Degraded MIT Fuel.........................................................62

Table 6.5.1.3-2. Stratified Layers with Degraded MIT Fuel Mixed with 15\% of HLW Glass Clay

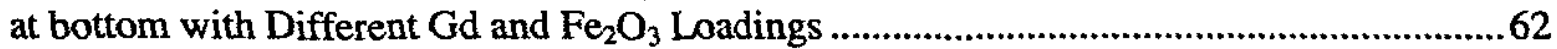

Table 6.5.2.1-1. Degraded ORR Fuel Homogenized In DOE SNF Canister with Iron Oxide From

Degraded Basket (No Boron Remaining; Canister Surrounded by Clay)

64

Table 6.5.2.2-1. Layer of Degraded ORR Fuel on Top of Degraded HLW Glass Clayey Material

Table 6.5.2.3 1. Degraded ORR Fuel at the Bottom of Waste Package Mixed With Various

Amounts of Clay From Degraded HLW Glass

Table 6.7-1. Probabilities (per waste package) of the Occurrence of Potentially Critical

Configurations for Alternative Criticality Control Materials.

Configurations for Alternative Criticality Control Materials.... 


\section{Evaluation of Codisposal Viability for Aluminum-Clad DOE-Owned Spent Fuel: Phase II - Degraded Codisposal Waste Package Internal Criticality}

\section{Purpose}

This evaluation is prepared by the Mined Geologic Disposal System (MGDS) Waste Package Development Department (WPDD) to provide an assessment of the viability of disposing of aluminum-based Department of Energy-owned research reactor spent nuclear fuel (DOE SNF) in a codisposal waste package with five canisters of vitrified high-level waste (HLW). This is the second of three phases of this work. Analyses were performed that considered geochemistry, geometric configurations, criticality control, and critical event probabilities for degraded aluminum-based SNF, DOE SNF canisters, and other components of the codisposal waste package. The objective was to provide sufficient detail to establish the technical viability of the aluminum-based DOE SNF canister option. This report focuses on the DOE SNF canister and on how it interfaces with the waste container and repository.

Two DOE SNF fuel types were selected by the Alternative Technology Program of the Westinghouse Savannah River Company (reference 1) as representative of the range of variations (particularly with respect to criticality) found in Al-based research reactor fuels. These two fuel types were the high-enrichment Massachusetts Institute of Technology (MIT) reactor fuel and the medium-enrichment Oak Ridge Research (ORR) reactor fuel. The MIT fuel has an initial

| maximum uranium enrichment of 93.5 weight percent ${ }^{235} \mathrm{U}$, and the ORR fuel has an initial maximum uranium enrichment of 20.56 weight percent ${ }^{235} \mathrm{U}$.

The Phase I criticality calculations, reported in reference 2, were performed for intact fuel contained within the codisposal canister (i.e., DOE SNF canister) for fully flooded conditions as typically assumed as worst case for both transport and disposal. Sufficient criticality analyses of the potential degraded states of MIT and ORR fuel within an intact codisposal canister basket were also performed in order to establish the quantity of stainless steel/boron alloy needed to ensure subcriticality if the fuel degrades within an intact basket. Thermal, structural, and shielding analyses were also performed for intact fuel contained within the codisposal canister for repository conditions as documented in the Phase I report.

This Phase II report evaluates the possibility and probability of criticality in a more severely degraded mode in which the fissile material could be released from the codisposal canister and reconfigured into a potential critical mass (assuming sufficient moderator) within the waste package. Subsequent Phase III work will evaluate the possibility and probability of criticality in degraded mode scenarios in which the released fissile material is transported out of the waste package and accumulates in the drift or host rock of the repository. The technical viability of the codisposal waste package (WP) shown in the Phase I report can be regarded as final since Phases II and III do not involve any further thermal, structural, or shielding analysis. The criticality control measures within the DOE SNF canister were modified as a result of evaluations in Phase II. Phase III evaluations might identify the need for additional criticality control measures or reductions in the fissile mass loading of DOE SNF canisters. 


\section{Evaluation of Codisposal Viability for Aluminum-Clad DOE-Owned Spent Fuel: Phase II - Degraded Codisposal Waste Package Internal Criticality}

\section{Quality Assurance}

The Quality Assurance (QA) program applies to this document. The work reported in this document is part of the preliminary WP design analysis that will eventually support the License Application Design phase. This waste package design activity, when appropriately confirmed, can affect the proper functioning of the MGDS waste package. The Quality Administrative Procedure (QAP) QAP-2-3 evaluation entitled Classification of Permanent Items Classification of the Preliminary MGDS Repository Design (reference 3, TBV-228) has identified the waste package as an MGDS item important to safety, waste isolation, and physical protection of materials. The Waste Package Operations responsible manager has evaluated this criticality analysis activity in accordance with QAP-2-0, Conduct of Activities. The QAP-2-0 activity evaluation (reference 4) has determined that work performed for this analysis is subject to Quality Assurance Requirements and Description (reference 5). As specified in NLP-3-18, Documentation of QA Controls on Drawings, Specifications, Design Analyses, and Technical Documents, this activity is subject to QA controls.

All design inputs which are identified in this document are for the preliminary stage of the WP design process; all of these design inputs will require subsequent confirmation (or superseding inputs) as the waste package design proceeds. This document will not directly support any Department of Energy (DOE) Office of Civilian Radioactivity Waste Management (OCRWM) construction, fabrication, or procurement activity and therefore is not required to be procedurally controlled as TBV (to be verified). In addition, the inputs associated with this document are not required to be procedurally controlled as TBV. However, any data from this document used for input into OCRWM documents supporting construction, fabrication, or procurement are required to be controlled as TBV in accordance with the appropriate procedures.

The specific activities involved with the production and review of this document have been. performed according to an approved Technical Document Preparation Plan (reference 6).

\section{Method}

The methodology used for these analyses of possible criticality for DOE SNF is similar to that used for corresponding evaluations of commercial SNF. In most cases the same computer codes are used for corresponding analyses. The same regulatory requirements are used, wherever appropriate.

Methods for criticality control in waste packages must be an intrinsic part of the packages which dictates the inclusion of specific neutron absorbing materials in the waste package structure. Neutron absorption in the WP structural materials and their degradation products contribute to criticality control but supplemental absorbing materials are also necessary to provide assurance that criticality control requirements for waste packages will be met. These analyses focus on the use of boron (B) and gadolinium (Gd) as the internal criticality control materials since both materials are well characterized and readily available from having been used extensively in commercial systems for reactivity control. Other neutron absorbing materials such as hafnium (Hf) were not included in the analyses based on considerations of cost and neutron absorbing 


\section{Evaluation of Codisposal Viability for Aluminum-Clad DOE-Owned Spent Fuel: Phase II - Degraded Codisposal Waste Package Internal Criticality}

efficiency.

The specific methodology for evaluating criticality within the degraded waste package consists of the following activities:

1) comprehensive degradation scenarios are developed based on the range of degradation rates for the individual waste package components;

2) the geochemical and physical processes involved in the degradation scenarios are quantified, using verified computer codes, and are used to determine the compositions of the materials remaining in the waste package (after degradation) and to.identify specific configurations that have significant separation between the highly fissile ${ }^{235} \mathrm{U}$ and the neutron absorber material; and

3) the criticality potential ( $\mathrm{k}_{\mathrm{eff}}$ ) of the resulting configurations is evaluated.

These three methodology steps are further explained in the following subsections. Additional detail is provided with the implementation of the methodology in Section 6.

\subsection{Degradation Scenarios}

Degradation scenarios for this analysis focus on ones involving water dripping into the WP since water is needed for moderation. Scenarios involving high $(>95 \%)$ relative humidity affect WP corrosion but are not important for criticality control. Thus, all degradation scenarios considered in this analysis begin with some enhanced dripping on the waste package, followed by the formation of some depression or deposit which can serve to capture a small amount of water to begin pit corrosion into the upper portion of the waste package outer barrier. If the dripping continues long enough, the pit will penetrate both the outer and inner barriers of the waste package. Based on the best available and conservative corrosion estimates, it is expected that at least 3,000 and 10,000 years will be required for penetration of both barriers. This estimate is offered for information purposes only since actual time of penetration makes no difference because all of the results reported in this document measure time from the initial aqueous penetration of the waste package. Next in these hypothetical scenarios is the entry of water into the waste package, followed by the onset of corrosion of the individual canisters. Following this, there is a range of possible scenario variations depending on which canisters are wetted first and how fast they corrode. The representative scenarios and their resulting configurations are presented in Sections 6.2 and 6.3, respectively.

\subsection{Geochemistry Analysis}

The geochemical and physical processes involved in the degradation scenarios are quantified through computer simulations with the EQ3/6 code package (reference 7) to determine compositions of materials remaining in the WP and identify particular configurations affecting criticality control. The EQ3/6 simulations do not model any effects of colloidal formation. In the event colloids containing fissile material do form, they would contribute to the transport of fissile material out of the WP, thereby decreasing the likelihood of an internal criticality.

The results of this part of the analysis methodology are expressed in the following forms: 


\section{Evaluation of Codisposal Viability for Aluminum-Clad DOE-Owned Spent Fuel: Phase II - Degraded Codisposal Waste Package Internal Criticality}

- Fissile concentrations in solution as a function of time (from the output of EQ6 sequences . over times up to 140,000 years).

- Amount of fissile material released from the waste package as a function of time (which thereby reduces the chance of criticality within the waste package).

- Concentrations of neutron absorbers, such as Gd, in solution and precipitated as a function of time (from the output of EQ6 sequences over times up to 140,000 years).

\subsection{Identification of Final Configurations for Neutronics Evaluations}

The results of the scenario generation are screened to identify potentially critical configurations. The principal features of such configurations are:

1) an accumulation of a significant amount of ${ }^{235} U$,

2) a significant amount of moderator, and

3) an absence of neutron absorbers.

The threshold values of the parameters associated with these features are based on published single parameter criticality limits (reference 8 ) and are set conservatively to assure that all critical configurations will be identified.

\subsection{Neutronics}

The reactivity of the DOE SNF canister within a waste package is analyzed for criticality with the MCNP4A computer code (reference 9) as the SNF and other waste package components degrade. All calculations are performed with the fresh fuel isotopics; i.e., there is no credit for fuel burnup (see Section 4.3, Assumption 4.3.2). The reactivity of the codisposal canister was evaluated for both MIT and ORR SNF.

The material compositions and geometries analyzed are based on the configurations generated by the geochemistry analysis described in Section 3.2, and identified according to the screening criteria mentioned in Section 3.3. Variations on the basic configurations were used for parametric analyses to identify worst cases, which determine minimum amounts of neutron absorber material needed. The basic configurations, together with their variations, cover the range of possibilities with respect to the removal of uranium or neutron absorber from the waste package and the range of water concentrations in the waste package to serve as moderator and reflector. 


\section{Evaluation of Codisposal Viability for Aluminum-Clad DOE-Owned Spent Fuel: Phase II - Degraded Codisposal Waste Package Internal Criticality}

\subsection{Evaluation of Probability of Occurrence of Potentially Critical Configurations}

For configurations identified by the scenario/configuration generation process (Sections 3.1 through 3.3, above), and found to have the potential for achieving criticality (Section 3.4), the probability of occurrence of a criticality event is estimated. This probability is estimated by combining the estimated probabilities of the required parameter values for the individual processes of the scenario.

\section{Design Inputs}

All design inputs which are identified in this document are for the preliminary stage of the design process; all of these design inputs will require subsequent confirmation (or superseding inputs) as the DOE SNF codisposal canister and waste package designs proceed. This document will not directly support any Civilian Radioactive Waste Management System (CRWMS) construction, fabrication, or procurement activity and therefore, is not required to be procedurally controlled as TBV.

\subsection{Design Parameters}

\subsubsection{Codisposal Waste Package}

The codisposal waste package containing 5 HLW canisters surrounding a DOE SNF codisposal

canister is shown in Figure 4.1-1. The barrier materials are typical of those used for commercial SNF waste packages. The inner barrier is composed of $20 \mathrm{~mm}$ of Alloy 625 serving as a corrosion resistant material, and the outer barrier is composed of a $100 \mathrm{~mm}$ of carbon steel serving as a corrosion allowance material (reference 2). During the course of the analysis for this revision, the nominal design of the waste package was modified by replacing the Alloy 625 inner barrier with Alloy C-22 (reference 10). The impact of this change was evaluated, and it was found that thể small effect would have made the result less conservative (reference 34 , Section 4.1.3). Therefore, the analysis for this revision was completed with the continued use of Alloy 625. The corrosion rate of $\mathrm{C}-22$ is included in Table 4.1.6-1 for comparison purposes only.

\subsubsection{HLW Glass Pour Canisters}

The Savannah River Site (SRS) Defense Waste Processing Facility (DWPF) HLW canister is a cylindrical stainless steel (Type 304L) shell with an outer diameter of approximately $610 \mathrm{~mm}$ (24.00 inch), a $9.525 \mathrm{~mm}$ wall thickness, and a nominal length of $3 \mathrm{~m}$ (reference 11, p. 3.3-4). The canister inside volume is $0.736 \mathrm{~m}^{3}$ and the glass weight is $1682 \mathrm{~kg}$ (reference $12, \mathrm{p}$. 3.3-6). HLW glass occupied $85 \%$ of the canister's volume. The nominal dimensions of the canister are used for these analyses. 


\section{Evaluation of Codisposal Viability for Aluminum-Clad DOE-Owned Spent Fuel: Phase II - Degraded Codisposal Waste Package Internal Criticality}

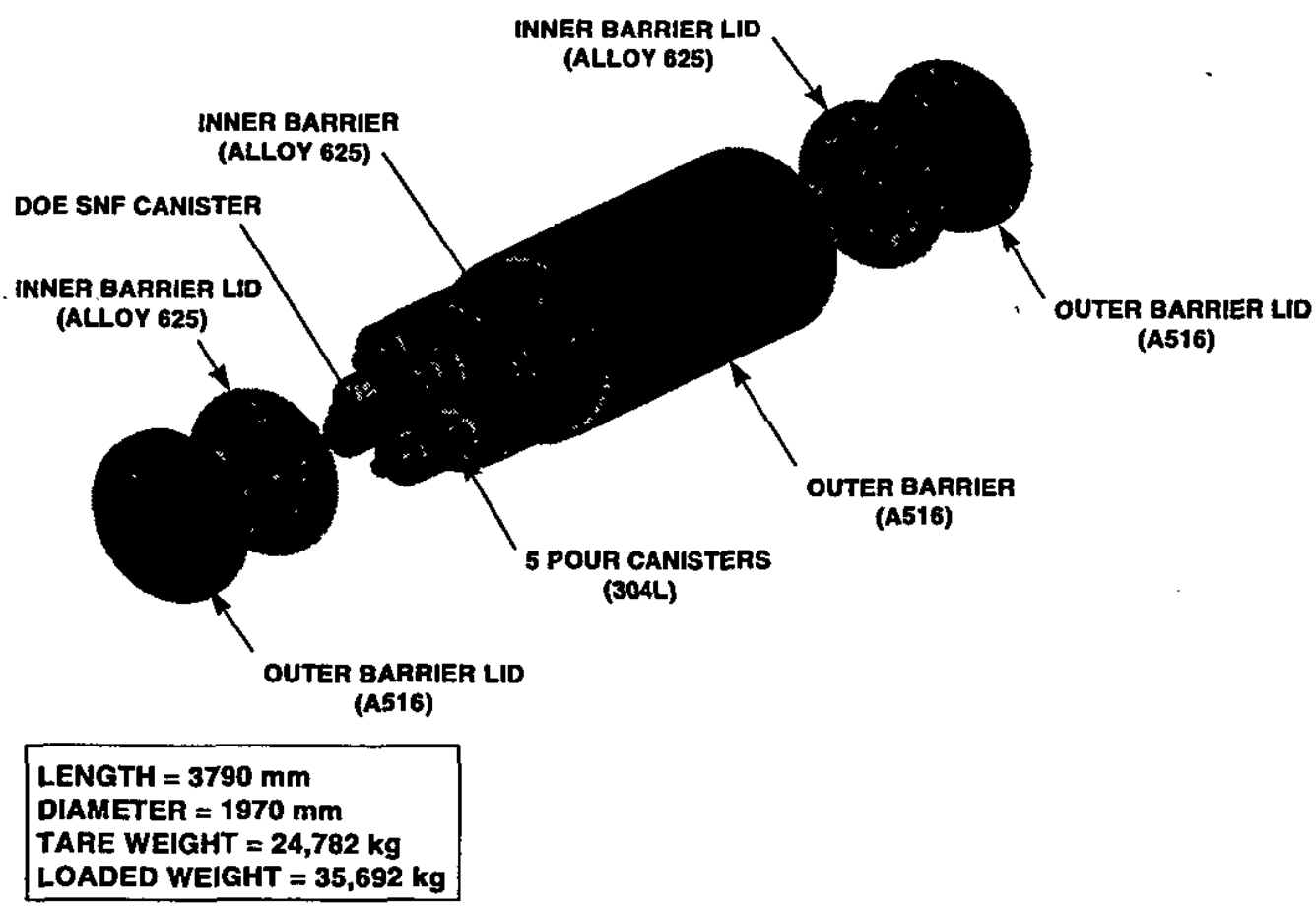

Figure 4.1-1. Codisposal Waste Package Assembly

\subsubsection{Codisposal Canister}

The conceptual design for the DOE SNF canister is taken from reference 2. The canister is a right circular cylinder of stainless steel XM-19 that contains a stainless steel $316 \mathrm{~L}$ basket. DOE SNF is to be loaded into the basket. The dimensions for the DOE SNF canister are a $439.3 \mathrm{~mm}$ outer diameter with a $15 \mathrm{~mm}$ wall thickness. The DOE SNF canister contains basket locations for 16 MIT or 10 ORR SNF assemblies in four layers as illustrated in Figure 4.1-2 (Assumption 4.3.1). Stainless steel/boron alloy ( $10 \mathrm{~mm}$ thick) is used to separate each layer from the adjacent layer within the canister. In the MIT SNF canister, stainless steel/boron alloy is also used in the basket between each assembly. The length of the canister is defined for this analysis as the length of four stacked fuel assemblies plus tolerances and between-layer (axial) separator plate thicknesses as in the Phase I analysis (reference 2). The MIT SNF canister length is nominally $2628 \mathrm{~mm}$ long and the ORR SNF canister is $2901 \mathrm{~mm}$ long. Canisters having a uniform length could be used with appropriate design changes, such as a solid spacer above the upper basket position for MIT SNF. Otherwise, use of the same canister size for both SNF types will result in a higher $\mathrm{H} /{ }^{235} \mathrm{U}$ ratio for MIT SNF and an increased $\mathrm{k}_{\text {eff. }}$. 
Evaluation of Codisposal Viability for Aluminum-Clad DOE-Owned Spent Fuel: Phase II - Degraded Codisposal Waste Package Internal Criticality

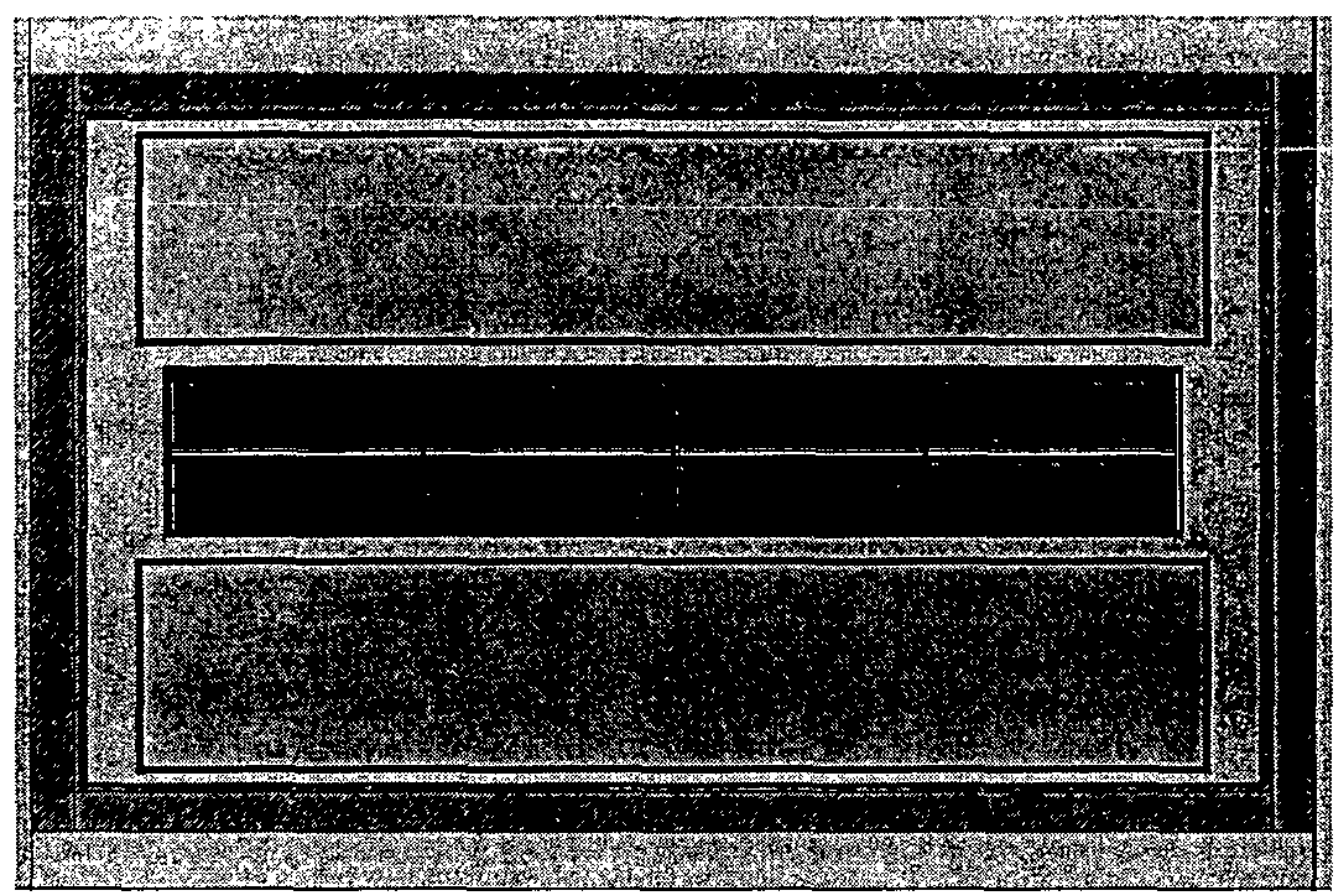

Figure 4.1-2. Longitudinal Cross-Sectional View of the Codisposal Waste Package

The MIT SNF codisposal canister basket consists of plates formed into parallelogram slots that fit into a steel disk to provide structural support for the SNF as shown in Figure 4.1-3. Panels of stainless steel/boron $2.54 \mathrm{~mm}$ thick are attached to one side of each slot to provide neutron attenuation between the slots. Stainless steel/boron in-row separator plates, $2.13 \mathrm{~mm}$ thick, are provided between adjacent pairs of MIT SNF assemblies to reduce neutronic interaction between adjacent assemblies. The rhomboidal slots provide a $1.72 \mathrm{~mm}$ nominal clearance around the MIT assembly. The inner diameter of the codisposal canister is $409.3 \mathrm{~mm}$. 
Evaluation of Codisposal Viability for Aluminum-Clad DOE-Owned Spent Fuel: Phase II - Degraded Codisposal Waste Package Internal Criticality

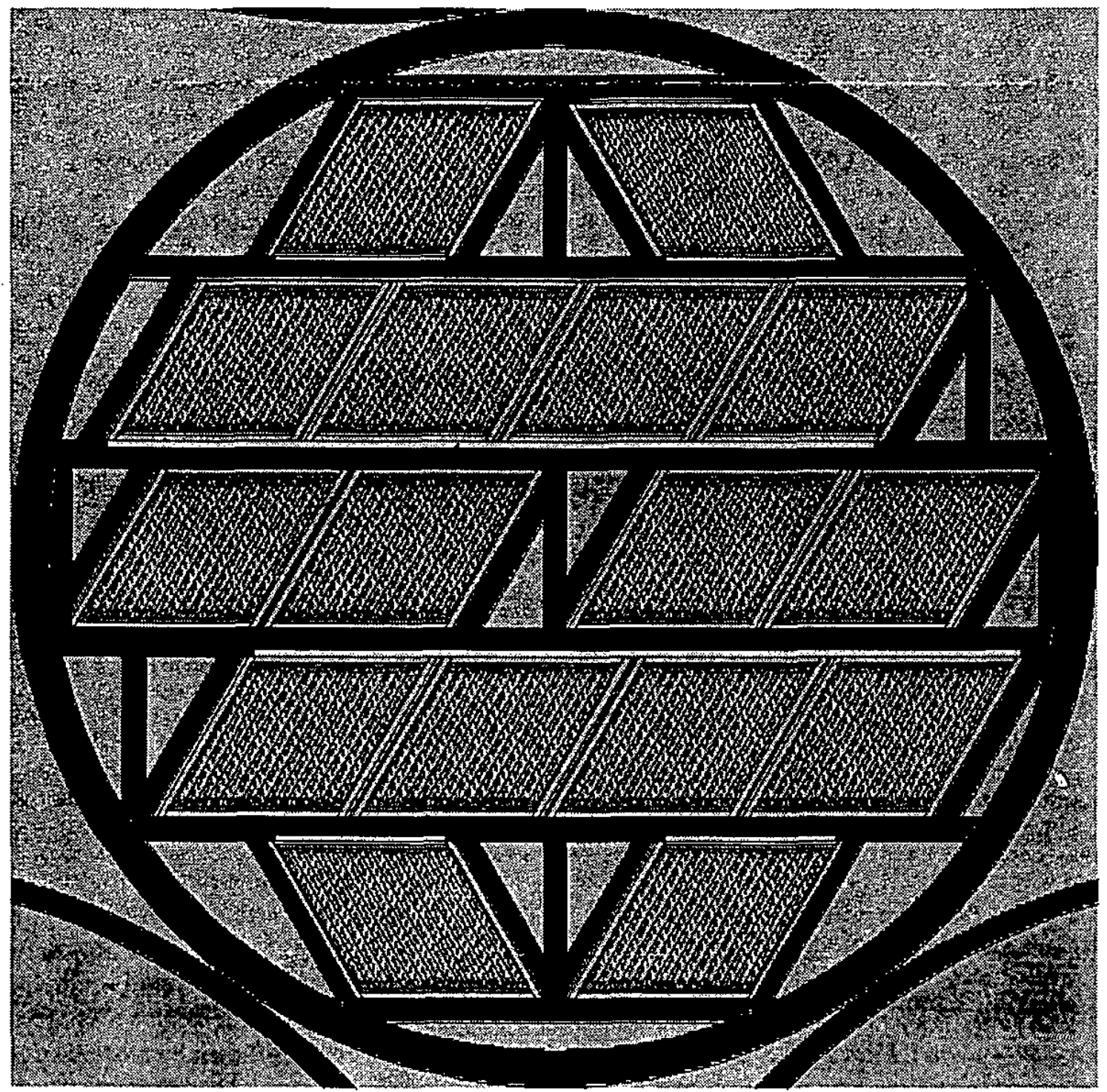

Figure 4.1-3. MIT SNF Canister Radial Cross-Sectional View 
Evaluation of Codisposal Viability for Aluminum-Clad DOE-Owned Spent Fuel: Phase II - Degraded Codisposal Waste Package Internal Criticality

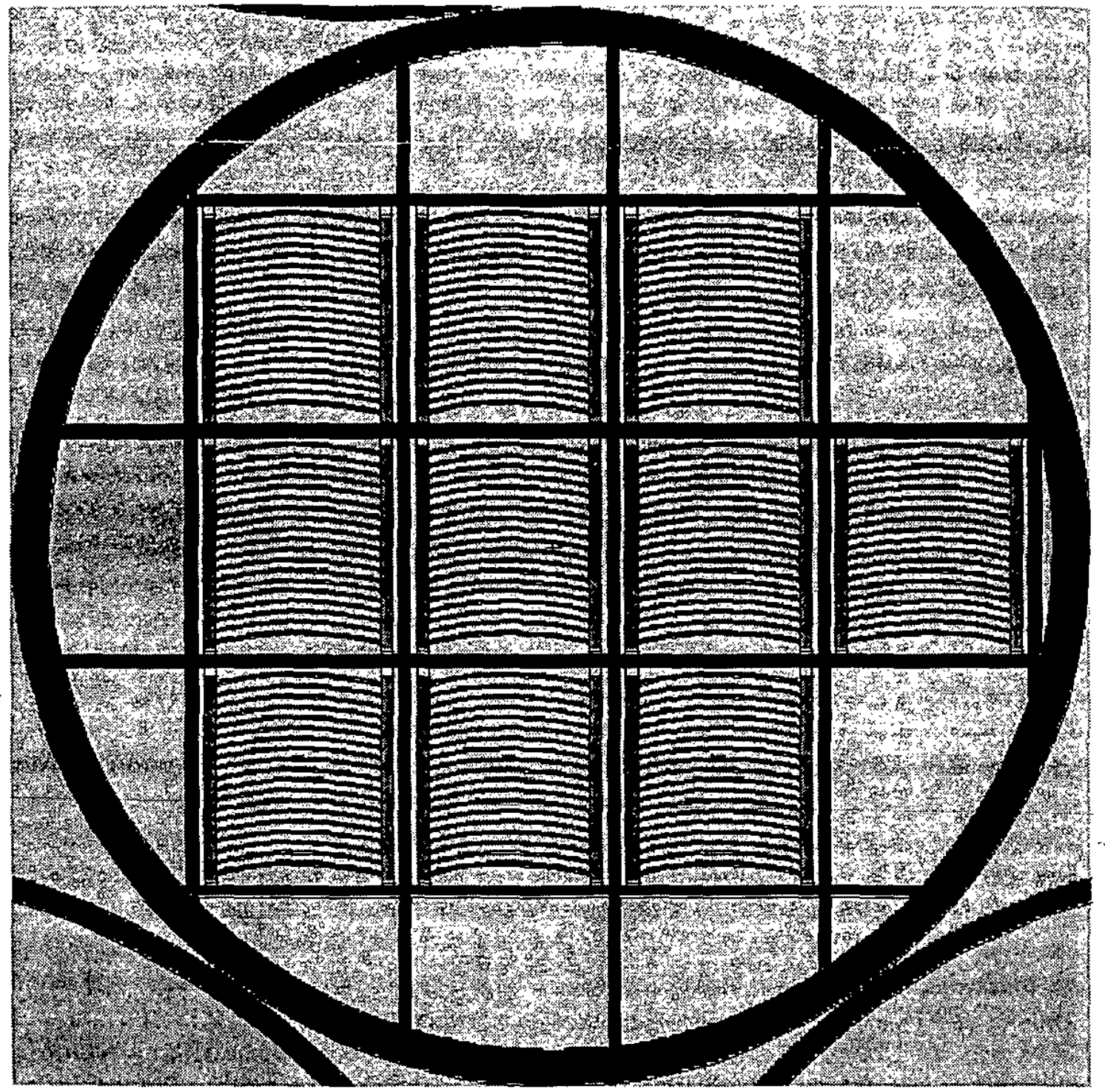

Figure 4.1-4. ORR SNF Canister Radial Cross-Sectional View

The ORR SNF codisposal canister basket consists of plates formed into ten rectangular tubes (5.0 $\mathrm{mm}$ wall thickness) aligned to form straight structural load paths progressing from one side of the basket to the other as shown in Figure 4.1-4. The tubes do not contain boron neutron absorber materials due to the moderate enrichment and low ${ }^{235} U$ loading of the ORR fuel assemblies. A nominal clearance of at least $2.54 \mathrm{~mm}$ is provided for the assembly in the basket.

As a result of the difference in the MTT and ORR assembly sizes, uranium enrichment, and uranium loading, the amount of ${ }^{235} \mathrm{U}$ per canister is significantly different. The MIT SNF canister with 64 fuel elements has $\mathrm{a}^{235} \mathrm{U}$ loading of $32.9 \mathrm{~kg}$ ( $35.2 \mathrm{~kg}$ of $\left.\mathrm{U}\right)$. The ORR SNF canister with 40 fuel elements has a ${ }^{235} \mathrm{U}$ loading of $13.9 \mathrm{~kg}(67.5 \mathrm{~kg}$ of U). 


\section{Evaluation of Codisposal Viability for Aluminum-Clad DOE-Owned Spent Fuel: Phase II - Degraded Codisposal Waste Package Internal Criticality}

\subsubsection{Al-Based DOE SNF}

\subsubsection{Massachusetts Institute of Technology SNF}

The characteristics of the MIT SNF were obtained from the MIT fuel data package (Appendix A of reference 1). The geometry of the MIT plate/assembly were taken from drawings (R3F-3-2, R3F-1-4) provided by Savannah River Site (SRS) as part of reference 1. The MIT fuel assembly is constructed from 15 flat plates tilted at a sixty.degree angle.resulting in an assembly that has a rhomboidal (equilateral parallelogram with $60^{\circ}$ acute angles) cross section, instead of the more common square or hexagon cross section. The MIT fuel length values used in these analyses are shorter than the original as-built length of the MIT assembly because the top and bottom ends of the assembly, which do not contain uranium materials, have been removed by cutting. The fuel plates consist of an aluminum cladding over an uranium/aluminum $\left(\mathrm{U}-\mathrm{Al}_{\mathrm{x}}\right.$ ) alloy. The maximum fuel mass for the MIT assembly is 514.25 grams of ${ }^{235} \mathrm{U}$ with an enrichment of 93.5 weight percent and one weight percent of ${ }^{234} \mathrm{U}$ The amount of aluminum present in the $\mathrm{U}-\mathrm{Al}_{\mathrm{x}}$ alloy fuel meat is 30.5 weight percent. ...

\section{Fuel Plates}

The fuel plates are $6.48208+0.00000,-0.00508 \mathrm{~cm}$ wide $(2.552+0.000,-0.002$ inches $)$ and 58.42 $\mathrm{cm}$ (23 inches) long. The high precision of the metric dimensions result from exact conversion of dimensions from drawings in inches to centimeters and are not indicative of significanc $*$. All 15 plates are the same and have a finned cladding surface with a total thickness of $0.2032 \pm$ $0.00762 \mathrm{~cm}(0.080 \pm 0.003$ inches $)$ including a fin height of $0.0254 \pm 0.00508 \mathrm{~cm}(0.010 \pm 0.002$ inches) on both faces. The fuel alloy is $0.0762+0.000,-0.00508 \mathrm{~cm}(0.030+0.000,-0.002$ inches) thick, $5.52958+0.000,-0.47625 \mathrm{~cm}(2.177+0.000,-0.1875$ inches $)$ wide, and $56.8325 \pm$ $0.9525 \mathrm{~cm}$ (22.375 \pm 0.375 inches) long.

\section{Fuel Element}

The aluminum outer shroud which encloses the 15 fuel plates on 4 sides is a $6.1087 \mathrm{~cm}(2.405$ inch) outside dimension rhomboid with a $0.11176 \mathrm{~cm}(0.044$ inch) thick wall parallel with the fuel plates and a $0.47752 \mathrm{~cm}(0.188 \mathrm{inch})$ thick comb plate at $60^{\circ}$ to the fuel plates, with a nominal length (after cutting) of $59.35472 \mathrm{~cm}$ (23.368 inches). The parallel fuel plates are uniformly spaced within this rhomboid, angled $60^{\circ}$ to the comb plate. The plates are fixed relative to each other by comb plates along two sides and the lip of the end fittings across the top and bottom. Drawing R3F-1-4 (reference 1) shows a fuel plate center-to-center spacing of $0.40132 \mathrm{~cm}(0.158$ inch $)$, which is the spacing of the notches on the comb plates. 


\subsubsection{Oak Ridge Research SNF}

Details of the construction of the ORR fuel element are contained in drawings M-11495-OR-001 ("19 Plate Fuel Element Assembly \& Finish Machining", reference 1)), M-11495-OR-003 ("Misc. Details for ORR Fuel Element", reference 1), and M-11495-OR-004 ("Fuel Plate Details", reference 1). The element is constructed from 19 curved fuel plates that are held within two opposing aluminum comb plates. The ORR fuel length values used in these analyses are shorter than the original as-built length of the ORR assembly because the top and bottom ends of the assembly, which do not contain uranium materials, have been removed by cutting. Appendix A of reference 1 contains the material information for the ORR fuel. The fuel plates consist of an aluminum cladding over an U-Si-Al fuel material. The maximum fuel mass for the ORR assembly is 347 grams of ${ }^{235} \mathrm{U}$ with an enrichment of 20.56 weight percent. . The uranium present in the U-Si-Al alloy is 77.5 weight percent. There are 2 atoms of $\mathrm{Si}$ per 3 atoms of $\mathrm{U}$, and $\mathrm{Al}$ fills out the remainder of the fuel material.

\section{Fuel Plates}

The curved fuel plates are manufactured as flat laminated sheets that are formed to the $13.97 \mathrm{~cm}$ (5.5 inch) inner radius of curvature. Seventeen of the plates are inner plates, with a thickness of 0.125476 to $0.12954 \mathrm{~cm}(0.0494$ to 0.0510 inches $)$ and a $0.02667 \mathrm{~cm}(0.0105$ inch $)$ minimum aluminum cladding on both sides of a $0.0508 \mathrm{~cm}(0.020 \mathrm{inch})$ nominal fuel foil, which is assumed to have a tolerance of $0.0127 \mathrm{~cm}(0.005$ inches $)$ since this is the default for-the drawing; these plates are $7.10057 \mathrm{~cm}$ (2.7955 inches) wide (minimum) to $7.10819 \mathrm{~cm}(2.7985$ inches $)$ wide (maximum). Two of the plates are outer plates, with a thickness of 0.16002 to $0.16764 \mathrm{~cm}$ ( 0.063 to 0.066 inches), with a $0.04572 \mathrm{~cm}(0.018 \mathrm{inch})$ minimum cladding on both sides of a $0.0508 \mathrm{~cm}(0.020 \mathrm{inch})$ nominal fuel foil. These plates are $7.09295 \mathrm{~cm}(2.7925$ inches $)$ wide (minimum) to $7.10057 \mathrm{~cm}$ (2.7955 inches) wide (maximum). For the inner fuel plates, the width of the fuel foil allows a 0.32004 to $0.508 \mathrm{~cm}(0.126$ to $0.200 \mathrm{inch})$ inset from the edge of the plate on both sides. The overall length of the inner fuel plate is 62.5348 to $62.5602 \mathrm{~cm}(24.620$ to 24.630 inches) and the fuel foil is centered within the plate longitudinally, with an inset at each end of 0.80772 to $1.9685 \mathrm{~cm}(0.318$ to 0.775 inches $)$. For the outer fuel plates, the width of the fuel foil allows a 0.32004 to $0.50292 \mathrm{~cm}(0.126$ to $0.198 \mathrm{inch})$ inset from the edge of the plate on both sides. The overall lengths of the outer fuel plates are 68.8848 to $68.9102 \mathrm{~cm}(27.120$ to 27.130 inches) and a fuel foil is centered longitudinally within the plates, with an inset at each end of 3.99796 to $5.10794 \mathrm{~cm}$ (1.574 to 2.011 inches). The top and bottom ends of the inner and outer fuel foils are chamfered, but this trimming of the fuel material was neglected.

\section{Fuel Element}

The aluminum comb plates enclose the 19 fuel plates on 2 sides giving a cross section bounded by a rectangle having the approximate dimensions of $8.255 \mathrm{~cm}$ by $7.62 \mathrm{~cm}(3.25$ inch by 3.00 inch), and a nominal length (after cutting) of $68.8975 \mathrm{~cm}$ (27 1/8 inches). The fuel plates are uniformly spaced within this box and form a nearly square fuel/water region bounded by the $8.04926 \mathrm{~cm}$ ( $3.169 \mathrm{inch}$ ) longitudinal comb plate width. The plates are fixed relative to each other by comb plates along two sides and by a comb strap across the top and bottom. Drawing 


\section{Evaluation of Codisposal Viability for Aluminum-Clad DOE-Owned Spent Fuel: Phase II - Degraded Codisposal Waste Package Internal Criticality}

M-11495-OR-003 ("Misc. Details for ORR Fuel Element", reference 1) shows a fuel plate edgeto-edge spacing of 0.166 inch $(0.42164 \mathrm{~cm})$, which is the spacing of the notches on the comb plates.

\subsubsection{Water Chemistry}

The composition of water entering the waste package was taken to be the average of the measurements at the J-13 well at Yucca Mountain. Water from this well has been analyzed repeatedly over a span of at least two decades (reference 13). The composition is reproduced in Table 4.1.5-1 These parameters are consistent with the J-13. well water specified as typical in CDA TDSS 025 . The larger range of concentrations and $\mathrm{pH}$, characterized as variability in CDA TDSS 025, would not significantly effect the results for the following reasons: (1) The extreme conditions would be expected to last only a few hundred to 1,000 years (since for longer times the source material, e.g., concrete, would have completely degraded); and (2) the variability range of $\mathrm{pH}$ and concentrations are already covered by the extreme values generated by the EQ3/6 code for some of the cases presented here.

Table 4.1.5-1. Analyzed Composition of J-13 Well Water ${ }^{1}$

\begin{tabular}{|c|c|c|}
\hline \multicolumn{3}{|c|}{ J-13 water } \\
\hline Element & Molality & Mole Fraction \\
\hline $\mathrm{Na}$ & $1.99 \mathrm{e}-03$ & $1.20 \mathrm{e}-05$ \\
\hline $\mathrm{Si}$ & $1.02 \mathrm{e}-03$ & $6.11 \mathrm{e}-06$ \\
\hline $\mathrm{Ca}$ & $3.24 \mathrm{e}-04$ & $1.95 \mathrm{e}-06$ \\
\hline $\mathrm{K}$ & $1.29 \mathrm{e}-04$ & $7.74 \mathrm{e}-07$ \\
\hline $\mathrm{C}$ & $1.45 \mathrm{e}-04$ & $8.69 \mathrm{e}-07$ \\
\hline $\mathrm{F}$ & $1.15 \mathrm{e}-04$ & $6.89 \mathrm{e}-07$ \\
\hline $\mathrm{Cl} *$ & $2.15 \mathrm{e}-04$ & $1.29 \mathrm{e}-06$ \\
\hline $\mathrm{N}$ & $1.42 \mathrm{e}-04$ & $8.53 \mathrm{e}-07$ \\
\hline $\mathrm{Mg}$ & $8.27 \mathrm{e}-05$ & $4.97 \mathrm{e}-07$ \\
\hline $\mathrm{S}$ & $1.92 \mathrm{e}-04$ & $1.15 \mathrm{e}-06$ \\
\hline $\mathrm{B}$ & $1.24 \mathrm{e}-05$ & $7.44 \mathrm{e}-08$ \\
\hline$P$ & $1.27 \mathrm{e}-06$ & $7.63 \mathrm{e}-09$ \\
\hline $\mathrm{H}$ & $1.11 \mathrm{e}+02$ & $6.67 \mathrm{e}-01$ \\
\hline $\mathrm{O}$ & $5.55 \mathrm{e}+01$ & $3.33 \mathrm{e}-01$ \\
\hline Total & & $1.00 \mathrm{e}+00$ \\
\hline
\end{tabular}

This nominal composition was modified slightly (well within the standard deviation of the analyses) to achieve consistency with thermodynamic data as explained in detail in reference 34 , thus avoiding computational artifacts. In addition, trace quantities of elements present in the waste and/or metals were added to enable the chemical modeling.

* Adjusted from the nominal value of $2.014 \mathrm{e}-04 \mathrm{~m}$ to $2.1533 \mathrm{e}-4 \mathrm{~m}$ to produce electrical neutrality. 


\section{Evaluation of Codisposal Viability for Aluminum-Clad DOE-Owned Spent Fuel: Phase $\Pi$ - Degraded Codisposal Waste Package Internal Criticality}

\subsubsection{Chemical Reaction Rates}

The rates of aqueous corrosion and dissolution for the various solid forms in the waste package are given in Table 4.1.6-1. Considerable uncertainty exists in degradation rates and additional testing is needed to improve these data. The rates for glass are expressed in the standard intrinsic material units, $\mathrm{g} / \mathrm{m}^{2} /$ day. The rates for the various types of steel are expressed in microns per year under the standard assumption that all plates have a thickness much less than length or width. Effects on corrosion rates due to the development of galvanic cells between dissimilar materials are not specifically considered. Including such effects would have little impact on the results because the analysis is already conservative with respect to corrosion rates in aluminum and carbon steel.

Solubilities of a number of solids important for criticality control concerns depend upon a number of factors. In particular, solubilities of $\mathrm{Gd}_{2} \mathrm{PO}_{4}, \mathrm{Gd}_{2} \mathrm{O}_{3}$, and various boron and uranium containing solids depend strongly upon the solution chemistry as well as the solution $\mathrm{pH}$. Gadolinium phosphate, in particular, is highly insoluble and will precipitate in the presence of very low concentrations of phosphate over the entire $\mathrm{pH}$ range from 3 to 12 . The primary data for solubilities consist of equilibrium constants in the EQ3/6 database. Solubility and $\mathrm{pH}$ data for $\mathrm{Gd}, \mathrm{U}$, and Pu solids are given in tabular form in reference 34.

Table 4.1.6-1. Aqueous Corrosion Rates for Waste Package Materials

\begin{tabular}{|c|c|c|}
\hline Material & Rate, $\mu \mathrm{m} / \mathrm{yr}$ & Rate, $\mathrm{g} / \mathrm{m}^{2} / \mathrm{d}$ \\
\hline Alloy $625^{1}$ & $1.008 \mathrm{e}-02$ & - \\
\hline Alloy C-22 2 & $8.12 \mathrm{e}-06$ & \\
\hline Stainless Steel $316 \mathrm{~L}^{3}$ & $1.000 \mathrm{e}-01$ & - \\
\hline Stainless Steel $304 \mathrm{~L}^{3}$ & $1.500 \mathrm{e}-01$ & - \\
\hline Carbon Steel A516 ${ }^{4}$ & $3.000 \mathrm{e}+01$ & - \\
\hline Carbon Steel A516 $6^{4 a}$ & $2.223 e+01$ & - \\
\hline Borated Stainless Steel $316 \mathrm{~B} 6 \mathrm{~A}^{5}$ & $8.000 \mathrm{e}-01$ & - \\
\hline HLW glass ${ }^{6}$ & - & $2.791 \mathrm{e}-02$ \\
\hline HLW glass ${ }^{7}$ & - & $2.000 \mathrm{e}-04$ \\
\hline \multicolumn{3}{|c|}{$\begin{array}{l}{ }^{1} \text { Assumption } 4.3 .6 . \\
{ }^{2} \text { Reference } 14 . \\
{ }^{3} \text { Reference } 15 \text {, p. } 11 \text {. } \\
{ }^{4} \text { Reference } 16 \text {, Figure } 5.3-7 \mathrm{a}, \text { p. } 5-47 \text {, maximum rate at initial exposure in water } \\
{ }^{4 a} \text { Reference } 16 \text {, Figure } 5.3-7 \mathrm{a}, \mathrm{p} .5-47 \text {, rate reduced for conservatism. } \\
{ }^{5} \text { Reference } 15, \text { p. } 12 \text {, rate doubled for conservatism. } \\
{ }^{6} \text { Reference } 17 \text {, p. } 4 \text {, high degradation rate cases. }\end{array}$} \\
\hline
\end{tabular}

\subsection{Design Criteria}

All design inputs which are identified in this document are for the preliminary stage of the design process; all of these design inputs will require subsequent confirmation (or superseding inputs) as 


\section{Evaluation of Codisposal Viability for Aluminum-Clad DOE-Owned Spent Fuel: Phase II - Degraded Codisposal Waste Package Internal Criticality}

the DOE SNF codisposal canister and waste package designs proceed. This document will not directly support any Civilian Radioactive Waste Management System (CRWMS) construction, fabrication, or procurement activity and therefore is not required to be procedurally controlled as TBV. Specific data values and/or assumptions used in this report will not be identified as TBV since the document is considered as TBV. However, any data from this document used for input into OCRWM documents supporting construction, fabrication, or procurement are required to be controlled as TBV in accordance with the appropriate procedures.

The design of the Engineered Barrier System (EBS) segment will depend on neutronic, geochemistry, and probability analyses to demonstrate criticality safety of the WP in the repository. Criteria that relate to the analysis of the EBS are derived from the applicable requirements and planning documents. Requirements are provided in the Engineered Barrier Design Requirements Document (EBDRD, reference 19) as specific requirements for EBS design. The Controlled Design Assumptions Document (CDA, reference 20) provides guidance for requirements listed in the EBDRD which have unqualified or unconfirmed data associated with the requirement. The criteria applicable to analyses of waste package emplacement are equivalent to the applicable requirements, interface requirements, and criteria cited in the EBDRD.

The "TBD" (to be determined) terms identified in the available criteria in this section will not be carried to the conclusions of this document based on the rationale that the conclusions derived by this analysis are for preliminary design that will not be used as input into OCRWM documents supporting construction, fabrication, or procurement.

The following criteria are applicable to the design subject. Each criterion references the relevant EBDRD (reference 19) requirement from which it has been derived; however, it is not the intent of this evaluation to show direct compliance with the referenced requirements from the EBDRD.

| Rather, they are used as guidelines and design goals for the preliminary design.

\section{Criticality Control}

The EBDRD requirements 3.2.2.6 and 3.7.1.3.A (reference 19) both indicate that a WP criticality shall not be possible unless at least two unlikely, independent, and concurrent or sequential changes have occurred in the conditions essential to nuclear criticality safety. These requirements also indicate that the design must provide for criticality safety under normal and accident conditions, and that the calculated effective multiplication factor $\left(\mathrm{k}_{\mathrm{eff}}\right)$ must be sufficiently below unity to show at least a five percent margin after allowance for the bias in the method of calculation and the uncertainty in the experiments used to validate the methods of calculation.

CDA Assumption EBDRD 3.7.1.3.A (reference 20, p. 4-32) clarifies that the above requirement is applicable to only the preclosure phase of the MGDS, in accordance with the current DOE position on postclosure criticality. This assumption also indicates that for postclosure, the probability and consequences of a criticality provide reasonable assurance that the performance objective of 10CFR60.112 (reference 21) is met. While the Nuclear Regulatory Commission has not yet endorsed any specific change for 


\section{Evaluation of Codisposal Viability for Aluminum-Clad DOE-Owned Spent Fuel: Phase II - Degraded Codisposal Waste Package Internal Criticality}

postclosure, they have indicated that they agree that one is necessary.

\section{Geochemical Analysis}

The EBDRD (refercnce 19) requirement EBDRD 3.7.1.A indicates that packages for SNF and HLW shall be designed so that the in situ chemical, physical, and nuclear properties of the waste package and its interactions with the emplacement environment do not compromise the function of the waste packages or the performance of the underground facility or the geologic setting.

Similarly, EBDRD 3.7.1.2.G indicates that the container shall be designed so that neither its in situ chemical, physical and nuclear properties, nor its interactions with the waste form and the emplacement environment, compromise the function of the waste package or the performance of the natural barriers or engineered barriers.

This analysis contributes to satisfying the above two requirements by evaluating the chemical processes that will occur as the DOE SNF canister, DOE SNF waste form, HLW glass canisters, and the HLW glass degrade, following breach of the waste package. The results of the geochemical analysis will be used as input to criticality analyses that will determine if any of the resulting degraded configurations cause failure of the criticality control function of the waste package. Any assessment of whether the criticality control criteria are met will be performed in the subsequent criticality analyses.

\subsection{Design Assumptions}

Based upon the rationale that the conclusions derived in this document are for preliminary design and will not be used as input into documents supporting construction, fabrication, or procurement, a TBD or TBV will not be carried to the conclusions to this document.

The assumptions used in this document are:

4.3.1 The codisposal waste package contains $16 \mathrm{MIT}$ or 10 ORR DOE SNF assemblies in the basket cross section, and assemblies are stacked four high within each position in the fuel basket for a total of $64 \mathrm{MIT}$ or $40 \mathrm{ORR}$ assemblies. The basis for this assumption that these are the maximum number of assemblies of each type that can physically fit in the DOE SNF canister. This assumption is used in Section 4.1 and implicitly throughout Section 6.

4.3.2 The MIT and ORR fuel is assumed fresh (unburned) for criticality calculations. The basis for this assumption is that the National Spent Nuclear Fuel Program Criticality Team recently came to the consensus opinion that the benefit gained from burnup credit would not be significant enough to pursue for DOE SNF due to cost and lack of qualified data (reference 22). This assumption is used in Sections 3.4 and 6.5.

4.3.3 It is assumed that boron will be dissolved as rapidly as it is released by the corrosion of 


\section{Evaluation of Codisposal Viability for Aluminum-Clad DOE-Owned Spent Fuel: Phase II - Degraded Codisposal Waste Package Internal Criticality}

borated stainless steel. The basis for this assumption is that the boride particles contained in the borated stainless steel are likely to corrode and dissolve following degradation of the stainless steel, since they have a large surface-to-volume ratio, and since preliminary research indicates that they have corrosion rates similar to that of the stainless steel matrix (reference 23, p. VII-22). If the borides dissolve, the boron is likely to be transported out of the waste package with any flushing water. The further basis for this assumption is that it is conservative. For information purposes it should be noted that this assumption is consistent with preliminary electrochemical measurements performed by LLNL (reference 23) on a borated stainless steel similar in composition to the 316B6A stainless steel assumed for this design (Neutronit A978 austenitic stainless steel); this material is found to be noble with respect to the metal boride. Therefore, the release of the borides from the stainless matrix will be controlled by the corrosion of the matrix. This assumption is used throughout Section 6.5 (TBV)

4.3.4 The void space in the waste package is assumed to be fully flooded with water for criticality calculations. The basis for this assumption is that this is the most reactive condition and is conservative. This assumption is used in Section 6.5.

4.3.5 It is assumed that all degraded configurations considered credible in the geochemistry and degradation mode analysis (reference 34 ) will require criticality analysis even if they require more than 10,000 years to develop. The basis for this assumption is CDA Key 039 (reference 20) which indicates that the time period over which criticality control must be maintained is not defined, but is expected to be greater than 10,000 years. This assumption is used implicitly throughout Section 6.5.

4.3.6 Although Alloy 625 has been [but no longer is] specified as the material for the waste package inner barrier, the estimate of long term corrosion rate is based on very limited data. Therefore, the corrosion rate used here is stated as an assumption. This assumption is that the corrosion rate of Alloy 625 is no more than 10 percent of the corrosion rate of $316 \mathrm{~L}$ stainless steel. The justification for this assumption is that Alloy 625 is generally assumed to have corrosion properties similar to Alloy 825 (references 25 and 26), and the most recent measurements of Alloy 825 corrosion rate indicate that it is less than 10 percent of that for $316 \mathrm{~L}$ (reference 26). The conservatively high corrosion rate assumed for Alloy 625 resulted in virtually no effect on the simulations, because very little of the Alloy 625 had reacted by the time all of the other materials had degraded. Therefore, further analysis of the sensitivity to the corrosion rate was not necessary. This assumption applies to Sections 4.1.6, 6.2, and 6.3.

4.3.7 It is assumed that the corrosion rate for XM-19 is similar to $316 \mathrm{~L}$ stainless steel because both are austenitic grades and have similar compositions in the major alloying elements affecting corrosion, i.e., Chrome, Nickel, and Molybdenum ((see Table 4.1.3-1, reference 34). For purposes of calculating worst case corrosion time, the corrosion rate for XM-19 was conservatively assumed to be twice that for $316 \mathrm{~L}$ stainless steel. This assumption is used in Table 4.1.6-1 and in Table 6.3-1.

4.3.8 The Savannah River HLW canister is assumed to be a representative model for HLW 


\section{Evaluation of Codisposal Viability for Aluminum-Clad DOE-Owned Spent Fuel: Phase II - Degraded Codisposal Waste Package Internal Criticality}

canisters. Reference 12 specifies the geometry and materials of construction. The outer diameter is $0.6095 \mathrm{~m}$ and the thickness is $0.009525 \mathrm{~m}$. The canister inside volume is $0.736 \mathrm{~m}^{3}$ and the glass weight is $1682 \mathrm{~kg}$. The glass loading in each canister is $85 \%$ of the total volume. The basis for this assumption is that the SRS HLW glass is the most developed of the HLW types. This assumption is used implicitly throughout Section 6.

4.3.9 The waste package will be emplaced in-drift in a horizontal position. The basis for this assumption that this is consistent with CDA Key 011 and Key 066, reference 20. This assumption is used throughout Section 6.

4.3.10 It was assumed that $\mathrm{U}-\mathrm{Al}$ and $\mathrm{U}-\mathrm{Al}-\mathrm{Si}$ alloys would corrode at a rate resembling that for aluminum metal. The basis for this assumption is that $\mathrm{U}-\mathrm{Al}$ and $\mathrm{U}-\mathrm{Al}-\mathrm{Si}$ are thermodynamically unstable in the presence of water and atmospheric oxygen to approximately the same degree as is aluminum metal. Consequently, rather rapid corrosion is likely to occur. As long as the degradation of the aluminum fuel matrix occurs in a time frame much shorter than that for the HLW glass or other metals, errors in the fuel degradation rates have no significant impact on the results of the analyses in this report. This assumption applies to Sections 6.2 through 6.3.

4.3.11 It is assumed that the inner corrosion resistant barrier will react so slowly with the infiltrating water as to have negligible effect on the chemistry, because this metal corrodes very slowly compared to other reactions occurring in the waste package and to the rate at which soluble corrosion products will likely be flushed from the package. This assumption is used implicitly in Sections 6.2 through 6.3.

4.3.12 For purposes of estimating the fraction of neutronically 'significant material which could fall to the bottom of the basket in the DOE SNF canister, it is assumed that the waste package is oriented such that the large basket plates (shown horizontal in Figure 4.1-3) actually are horizontal to permit evaluation of the effects of potential stratification of corrosion products on criticality control. It is further assumed that the disposition of material from the plates which are angled to the large plates (shown in Figure 4.1.3) will be the same as for the horizontal plates. This assumption is made for modeling purposes only. The basis for this assumption is that it is conservative. Any material resting on top of a non-horizontal basket plate would tend to slide down the plate to the corner formed by the intersection of the plate with the canister wall. There would be one such corner for each basket plate, and the collection in such corners would be a more reactive geometry for criticality than a single collection at the bottom assumed here. The same considerations apply to corroded material from the angled plates. This assumption is used in Section 6.4.4.2

4.3.13 It is assumed that the fuel matrix will corrode at a rate of $2.6 \mathrm{e}-10 \mathrm{~g} / \mathrm{cm}^{2} / \mathrm{s}$ (reference 34) which is fast compared to the degradation rates of other material in the waste package in general, and material in the basket of the DOE SNF canister, in particular. At this rate, the aluminum fuel matrix will completely corrode in 10 years. The fuel matrix corrosion rates assume that the material is exposed to a water chemistry derived from J-13 water after reacting with degrading waste forms. Much lower rates can be obtained for 


\section{Evaluation of Codisposal Viability for Aluminum-Clad DOE-Owned Spent Fuel: Phase II - Degraded Codisposal Waste Package Internal Criticality}

situations where the water chemistry is carefully controlled but such situations are not applicable to waste package applications. This assumption applies to Section 4.1 and to Section 6.

4.3.14 It is assumed that the drip rates of water into the repository will vary within the range 0.1 $\mathrm{mm} / \mathrm{yr}$ to $50 \mathrm{~mm} / \mathrm{yr}$ over the long term. This range of drip rates is greater than the range of filtration rates given in TSPA-95 (reference 16); the upper limit of this range (50 $\mathrm{mm} / \mathrm{yr}$ ) is approximately equal to that given in reference 20 , TDSS 026 , for ambient fully mediated flow $\left(0.5 \mathrm{~m}^{3} / \mathrm{yr}\right.$ which is $50 \mathrm{~mm} / \mathrm{yr}$ averaged over a hypothetical waste package horizontal cross-section area of $10 \mathrm{~m}^{2}$ ). (The CDA TDSS 026 also specifies higher flow rates which are either intermittent, or last for less than a few hundred years. As such, they do not effect the long-term analysis ). Infiltration rate is the net flow into the ground at a small distance beneath the surface (precipitation minus evapotranspiration, minus runoff). Drip rate is the net flow into the repository. The difference is the lateral diversion, away from the repository, by relatively impervious layers between the surface and the repository. This difference is uncertain at the present time, but experiments are expected to provide definitive information within the next few years. Drip rate, in $\mathrm{mm} / \mathrm{yr}$, is converted to volumetric flow by multiplying by the WP maximum interior horizontal cross sectional area (i.e., $1.73 \times 3.04 \mathrm{~m}$ ).

4.3.15 It is assumed that any effects of contact of the dripping water with the drift liner will be minimal after the 3000 to 10,000 years which represent the earliest possible times of waste package breach. The justification for this assumption is as follows:

1) the drift liner on the top of the drift is expected to collapse with the roof support, well before 1000 years,

2) the travel time of water through the liner, while probably faster than the time through holes in the waste package barriers, will still be much less than the travel time through the rock above the repository,

3) water moving through the liner will be predominately along fractures, which after 3000 to 10,000 years, will most fully have reacted toward equilibrium with incoming water and will be little affected by diffusion of potentially high alkaline water residing within pieces of liner between fractures, and

4) even if the drift liner lasted beyond the 3000 to 10,000 years required to breach the waste package, the alkalinity would not add significantly to the high $\mathrm{pH}$ expected to be produced during the HLW glass degradation phase.

It should further be noted that a longer duration of the high $\mathrm{pH}$ period would only increase the probability of uranium being flushed from the waste package or to reduce the probability of neutron absorber being flushed from the waste package, both of which reduce the probability of criticality. Therefore, this assumption is conservative. This assumption is used in Sections 6.2 and 6.3.

4.3.16 For purposes of making a very conservative estimate of the probability of criticality for 


\section{Evaluation of Codisposal Viability for Aluminum-Clad DOE-Owned Spent Fuel: Phase II - Degraded Codisposal Waste Package Internal Criticality}

the MIT SNF, it is assumed that if the amount of neutron absorber is reduced below the thresholds calculated in the criticality analyses of Section 6.5 , and if there is sufficient water for moderation, then criticality will occur. This is equivalent to assuming that the contents of the waste package will always configure into the appropriate geometry. The justification for this assumption is that $i t$ is conservativc. This assumption is used in Section 6.7.

4.3.17 It is assumed that all the criticality control gadolinium in the waste package is available for neutron absorption. The basis for this assumption is the following calculation. Previous studies have calculated the neutron fluence in waste packages loaded with SNF. For the 64 MIT assembly waste package used in this study, the spontaneous fission and $(\alpha, \mathrm{n})$ neutron source is $1.2 \times 10^{3} \mathrm{n} / \mathrm{sec}$ after 5 years decay (for $35.2 \mathrm{~kg} \mathrm{U}$ burned to 8.1 GWd/MTU, reference 27, p. 40). Making the ultra-conservative approximation that the SNF neutron source fluence does not decrease with time, and that Gd captures all source neutrons, only $3.9 \times 10^{16} \mathrm{Gd}$ atoms would be burned out in 1 million years. This is only a miniscule fraction of the $3.83 \times 10^{24}$ atoms of $\mathrm{Gd}$ in the $1 \mathrm{~kg}$ of $\mathrm{Gd}$ recommended in this report. A very conservative upper bound for any SNF is provided by the much larger burnups of commercial SNF. The fluence for one BWR assembly burned to 49 GWd/MTU (reference 28 , p. II-45) is $\approx 10^{8} \mathrm{n} / \mathrm{sec}$ after 10 years decay. Under the conservative approximations of no source decrease with time and $100 \%$ absorption of all source neutrons in $\mathrm{Gd}$, a waste package fully loaded with 44 such assemblies would burn up only $1.4 \times 10^{23} \mathrm{Gd}$ atoms in 1 million years, less than $5 \%$ of the total.

\subsection{Codes and Standards}

Not Applicable. 


\section{Evaluation of Codisposal Viability for Aluminum-Clad DOE-Owned Spent Fuel: Phase II - Degraded Codisposal Waste Package Internal Criticality}

\section{Use of Computer Software}

\subsection{Scientific and Engineering Software}

The criticality evaluation of fresh fuel configurations was performed with the MCNP4A computer code that is identified with the Computer Software Configuration Item (CSCD): 30006V.4A (reference 9). MCNP4A calculates $k_{\text {eff }}$ for a variety of geometric configurations with neutron cross sections for elements and isotopes described in the Evaluated Nuclear Data File version B-V (ENDF-B/V). MCNP4A is appropriate for the fuel geometries and materials required for these analyses. The calculations using the MCNP4A software were executed on Hewlett-Packard UNIX workstations. The software qualification of the MCNP4A software, including problems related to calculation of $\mathbf{k}_{\text {eff }}$ for fissile systems, is summarized in the

Software Qualification Report for the Monte Carlo N-Particle code (reference 9). The MCNP4A evaluations performed for this design are fully within the range of the validation for the MCNP4A software used. Access to and use of the MCNP4A software for this analysis was granted by Software Configuration Management and performed in accordance with the QAP-SI series procedures.

An allowance for calculational bias and experimental uncertainties in criticality benchmark calculations must be made per the requirements listed in Section 4.2. Forty-seven criticality benchmark calculations representative for research reactor fuel were run based on reviewed experiments (reference 29). The sum of bias and uncertainty is less than 0.02 in $\mathrm{k}_{\text {eff }}$ for all cases (reference 30). One hundred nineteen highly enriched uranium (HEU) nitrate solution experiments in various configurations including no reflection, water (polyethylene) reflection, concrete reflection, boron absorber, gadolinium absorber, aluminum containers, stainless steel containers, single units, and arrays were run (reference 31 ). The average $k_{\text {eff }}$ for these cases minus the average statistical uncertainty is over 1.0 although the values for a few cases fall below 1.0. The worst experimental uncertainty is $0.015 \mathrm{k}_{\text {eff }}$ and is for a set utilizing gadolinium. The bias and uncertainty value was conservatively rounded up to $0.02 \mathrm{k}_{\text {eff }}$ for all homogeneous cases to account for geometry variations and material combinations not explicitly covered in the available criticality benchmark cases.

Concentrations of ${ }^{235} U$ and absorbers are considered when evaluating whether benchmarks are similar to or bound the cases documented in this report. In addition, two spectrum indexes are used in evaluating whether benchmarks are similar to or bound the cases documented in this report in regards to the neutron spectrum. These two indexes are the $\mathrm{H} /{ }^{235} \mathrm{U}$ ratio and the average energy of the neutron causing fission (AENCF). The $\mathrm{H}^{235} \mathrm{U}$ ratio is simply the number density for hydrogen divided by that for ${ }^{235} \mathrm{U}$ in the region containing ${ }^{235} \mathrm{U}$. The AENCF is the energy per source particle lost to fission divided by the weight per source neutron lost to fission from the "problem summary section" of an MCNP output. The $\mathrm{H}^{235} \mathrm{U}$ ratio and AENCF determined for cases documented in this report were compared to those values for benchmark cases (reference 31); the values for the benchmark cases were found to bound those for the cases in this report.

In this study, EQ3/6 (references 7 and 32) was used to provide:

1) a general overview of the nature of chemical reactions to be expected, 


\section{Evaluation of Codisposal Viability for Aluminum-Clad DOE-Owned Spent Fuel: Phase II - Degraded Codisposal Waste Package Internal Criticality}

2) the degradation products likely to result from corrosion of the waste forms and canisters, and

3) an indication of the minerals, and their amounts, likely to precipitate in the various geologic environments expected within the WP.

The programs have not been used outside the range of parameters for which they have been verified. The EQ3/6 calculations reported in this document used version $7.2 \mathrm{~b}$ of the code and were executed on the Hewlett-Packard 9000 Series 735 workstation.

The EQ3/6 (references 7 and 32) package has been verified by its present custodian, Lawrence Livermore National Laboratory, but it has not been transferred to the Management and Operating Contractor (M\&O) under the procedure QAP-SI-0, Rev. 3 (reference 33). Therefore all the results are considered TBV with respect to any CRWMS design supporting construction, fabrication, or procurement.

\subsection{Software Routines}

Microsoft Excel 97 spreadsheets (considered "Software Routines" under the QAP-SI series procedures) were used for simple calculations as documented in the QAP-3-9 Design Analyses . which support this technical report (reference 34). Microsoft Excel 97 was executed on an IBM compatible personal computer to provide data manipulation for the analyses.

The following software routines were developed for this study for the purpose of facilitating the setup and execution of successive cases of EQ6, by transforming the output of one case to the input of the following case: bldinpt.bat, bldinput.c, nxtinput.bat, nxtinput.c, postproc.c, lastpost.c, and allpost.bat. An individual EQ6 run diluted the solution constituents to reflect the inflow of fresh water and the routines periodically remove water and solutes corresponding to the inflow. These routines were verified by visual inspection in accordance with QAP-SI-0, 5.3.2C, (reference 33) by an individual independent of the person doing the original development in accordance with QAP-SI-0, 5.3.2A (reference 33), and are documented in reference 34, in accordance with QAP-SI-0, 5.3.2C, including all applicable information listed in QAP-SI-0, Attachment VI.

The $\mathrm{C}$ program pitgen.c was developed for the cutout analysis done in reference 34 , and summarized for this document in Section 6.4.4.2. The program does the following:

1) generates a rectangular array of square locations on a rectangular plate,

2) randomly selects, from this array, the locations for the occurrence of pits, and

3) after each of a specified number of pits is generated, scans the array to detect the areas which are completely encircled by pits, defines these areas as cutouts, and counts the area (number of square locations) enclosed in the cutouts.

This program was verified by visual inspection in accordance with QAP-SI-0, 5.3.2B, by an individual independent of the person doing the original development in accordance with QAP-SI0, 5.3.2A, and is documented in reference 34 , in accordance with QAP-SI-0, 5.3.2C, including all applicable information listed in QAP-SI-O, Attachment VI. 


\section{Evaluation of Codisposal Viability for Aluminum-Clad DOE-Owned Spent Fuel: Phase II - Degraded Codisposal Waste Package Internal Criticality}

\section{Design Analysis}

\subsection{Introduction}

This section describes the evaluations of degraded mode criticality for the MIT and ORR SNF. The exposition of these evaluations follows the methodology described in Section 3.

The scenarios that could result in the accumulation of a critical mass of uranium are described in Section 6.2; these results are presented primarily in terms of intermediate and final geometries of the waste forms and the degradation products, particularly uranium and the hydrated clay which serves as the primary moderator. It is assumed that the WP is in a horizontal position within the MGDS (Assumption 4.3.9). Section 6.3 summarizes, from reference 34, Sections 7.2 and 7.3, the geochemistry calculations leading to compositions of solids found in the final configurations. Section 6.4 summarizes the final configurations with particular emphasis on the possibilities for separation of uranium from the neutron absorber criticality control material, summarized from reference 32 , Section 7.4 .

Section 6.5 describes MCNP models and the results of the MCNP calculations on the models; this section is also a summary of more detailed results in reference 46, Sections 7.2 and 7.3. Parametric/sensitivity comparisons of the criticality results, with respect to changes in the most uncertain parameters, are given in Section 6.6. A very conservative estimate of probability of criticality is given in Section 6.7 , for comparison of alternatives only.

\subsection{Scenario Generation}

An overview of the scenario generation process is given by the flowchart in Figure 6.2-1.

This figure has three lower branches from a single stem at the top. The single stem represents the processes that are necessary for all scenarios that could lead to criticality, as already identified in Section 3.1. The three lower branches lead to final configurations with the uranium in the following locations:

1) in the bottom of the waste package,

2) on top of a clay layer filling most of the waste package, and

3) removed from the waste package.

Only the first two branches have potential for criticality inside the waste package and are of interest in the current analysis.

The intact configuration, from which all scenarios start, is shown in Figure 6.2-2. The HLW canisters are shown as having settled into the lowest gravitational state; the design may ultimately specify that there be some basket structure to maintain them in a more nearly symmetrical geometry. 


\section{Evaluation of Codisposal Viability for Aluminum-Clad DOE-Owned Spent Fuel: Phase II - Degraded Codisposal Waste Package Internal Criticality}

Two different possibilities for the initial stages of degradation are shown in Figures 6.2-3a and 6.2$3 b$, for the alternative possibilities of:

1) no early holes in the bottom of the waste package, and

2) an early hole large enough to drain all of the water and some of the clay, respectively.

The initial degradation with no early holes in the waste package bottom leads to the intermediate configurations shown in Figures 6.2-4, 6.2-5, and 6.2-6, which culminate in a layer of uranium mixed with clay at the bottom of the waste package. This sequence corresponds to the leftmost branch in the flowchart.

The initial degradation with a hole of the type illustrated in Figure 6.2-3b will lead to the sequence of configurations shown in Figures 6.2-7 and 6.2-8.

If the waste package bottom is breached, the flushing action for removing subsequent degradation products is simple flow-through; if the waste package bottom is not breached, or if any holes in the bottom are plugged with clay, the flushing action is maintained by flow near the water surface fed by thermally driven circulation within the waste package. This circulation, as well as any agitation produced by water drops falling on the clay as DOE SNF degradation products, have potential to spread the degradation products laterally to some extent, the limit of which is a uniform layer a shown in Figure 6.2-8. The flushing is at a volumetric rate equal to the input inflow rate (the product of the drip rate multiplied by the horizontal cross section area).

The sequences illustrated in Figures 6.2-2 through 6.2-8 focus on the configurations of the HLW canisters and contents in relation to the DOE-SNF canister within the waste package. Variations in the configuration within the DOE-SNF canister will exist also. Initially, the DOE SNF and basket will be intact as shown in Figure 6.2-2. The fuel will then degrade within each basket cell and could concentrate as a layer on the bottom plate of the cell or remain dispersed throughout the cell. The Phase I results (reference 2 ) indicated that the degraded fuel was most reactive when it was dispersed throughout the basket cell; therefore, the settling configuration is not considered further in this analysis. As the basket degrades the components could settle as shown in Figure 6.2-9 or the degradation products could be hydrated and remain dispersed within the basket as shown in Figure 6.2-5. The focus of the analysis for the degraded basket configuration is on the dispersed case shown in Figure 6.2-5 because it is the most reactive configuration. The settled configuration shown in Figure 6.2-9 is addressed for completeness in the criticality analysis in Section 6.5 . 
Evaluation of Codisposal Viability for Aluminum-Clad DOE-Owned Spent Fuel: Phase II - Degraded Codisposal Waste Package Internal Criticality

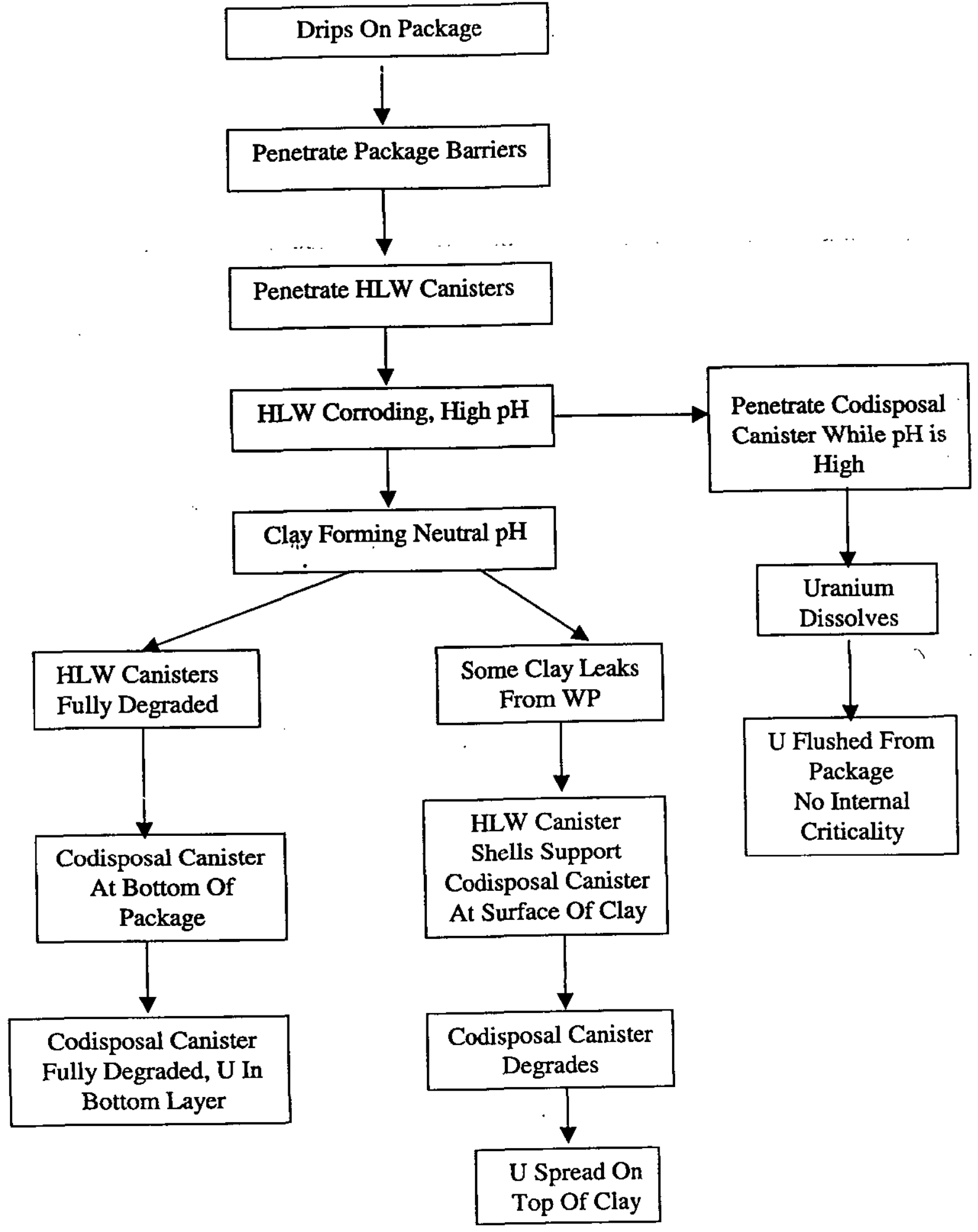

Figure 6.2-1. Internal Degradation Scenarios for Al-Clad DOE SNF 
Evaluation of Codisposal Viability for Aluminum-Clad DOE-Owned Spent Fuel: Phase II - Degraded Codisposal Waste Package Internal Criticality

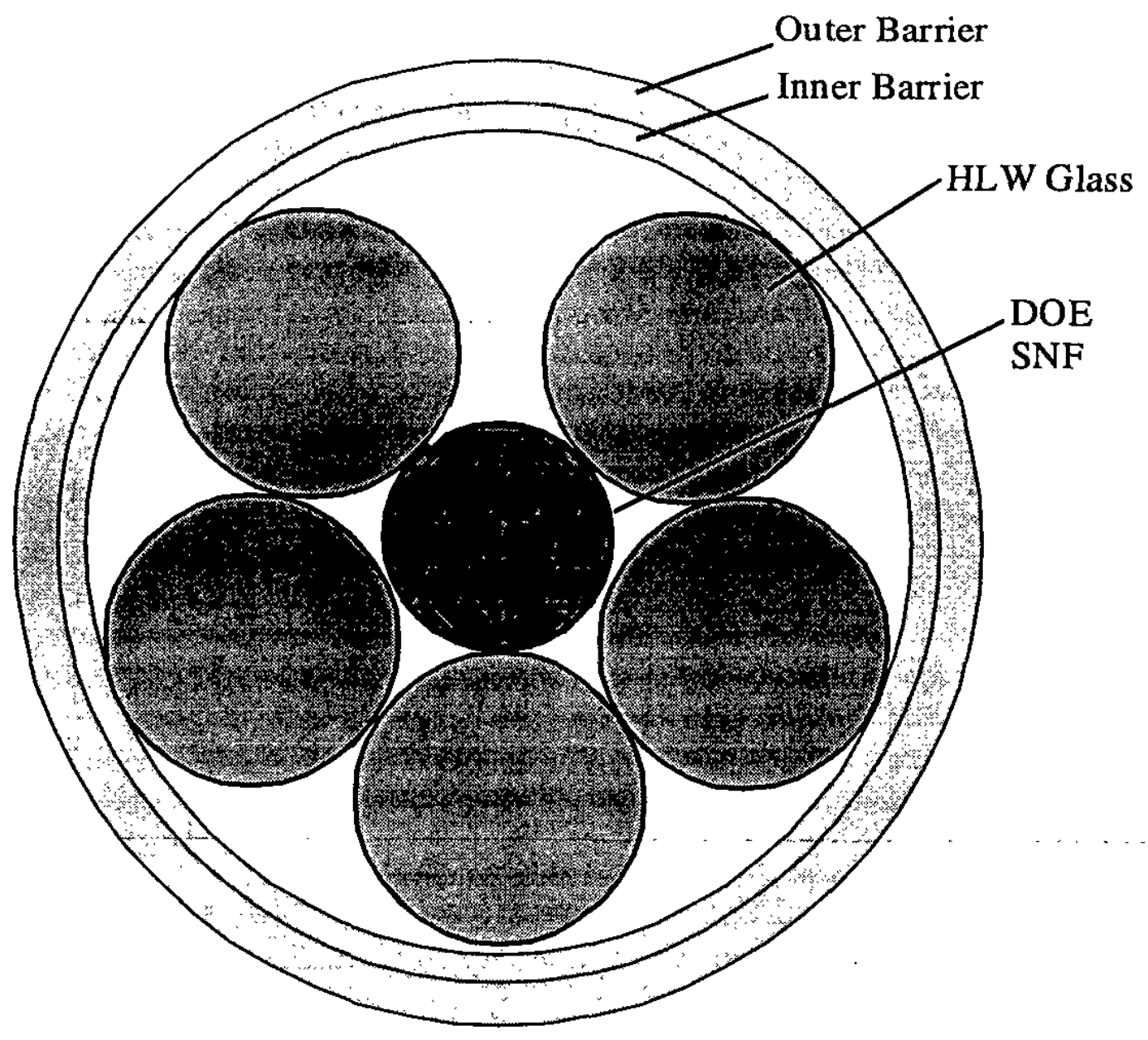

Figure 6.2-2. Cross Section of Waste Package Showing the DOE SNF Canister in the Center Surrounded by HLW Canisters 
Evaluation of Codisposal Viability for Aluminum-Clad DOE-Owned Spent Fuel: Phase II - Degraded Codisposal Waste Package Internal Criticality

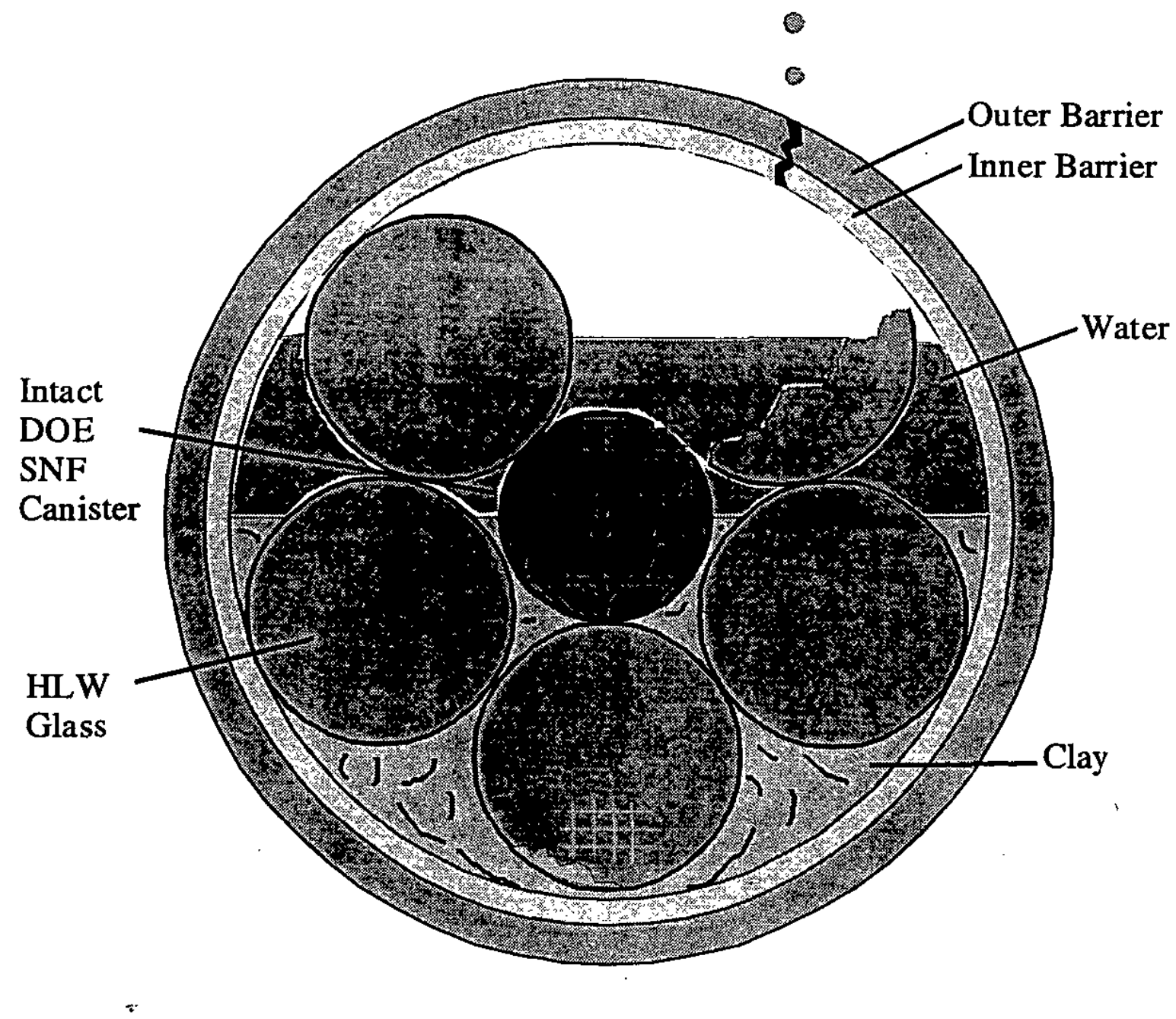

Figure 6.2-3a. Early Stage of Degradation; No Holes in the Bottom; Some Ponding Water; No Penetration of the DOE SNF Canister; Most of the HLW Canister Degraded 
Evaluation of Codisposal Viability for Aluminum-Clad DOE-Owned Spent Fuel: Phase II - Degraded Codisposal Waste Package Internal Criticality

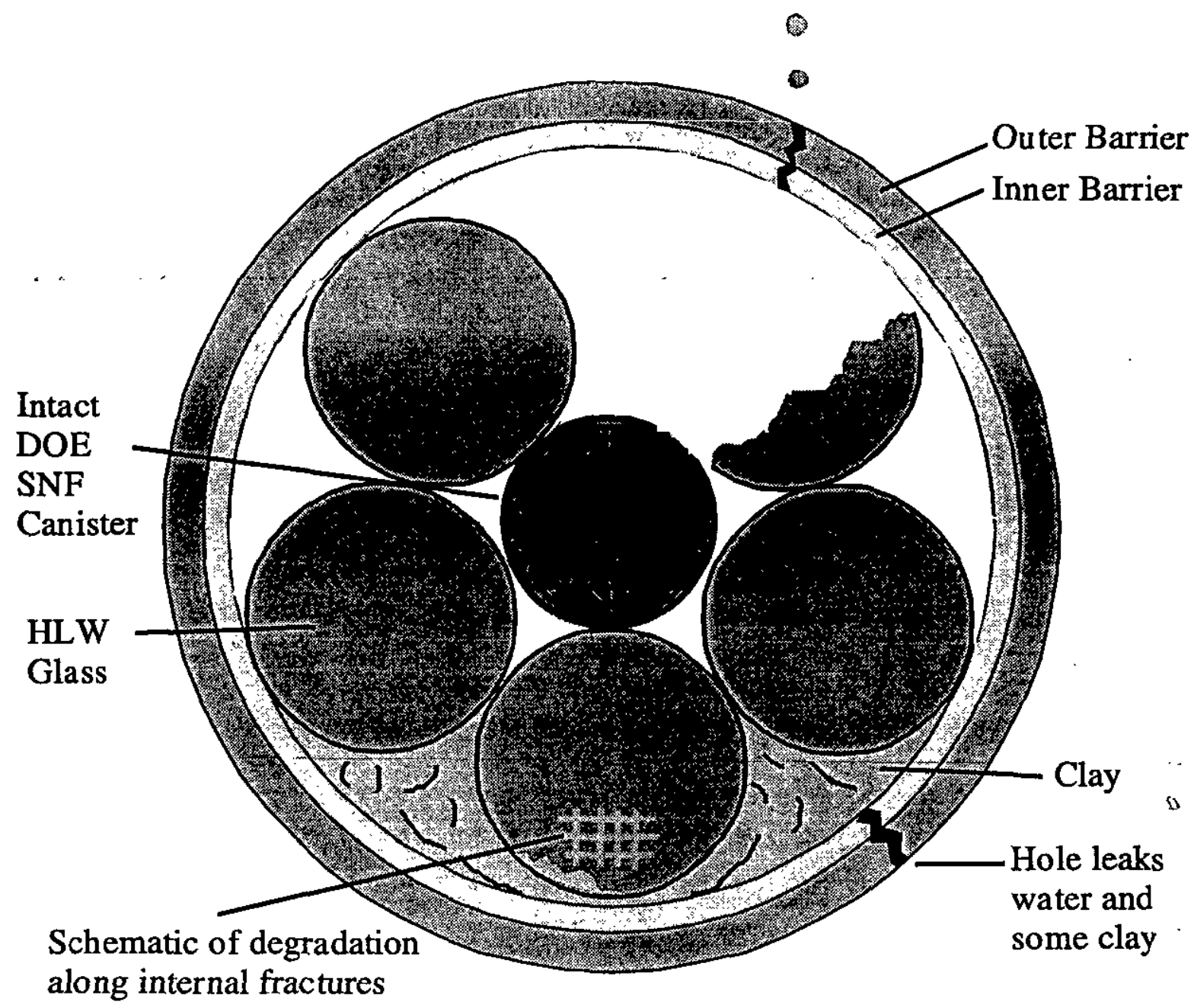

Figure 6.2-3b. Alternative Early Stage of Degradation; Hole in the Bottom Which Drains Water and Some of the Clay; No Penetration of the DOE SNF Canister 
Evaluation of Codisposal Viability for Aluminum-Clad DOE-Owned Spent Fuel: : Phase II - Degraded Codisposal Waste Package Internal Criticality

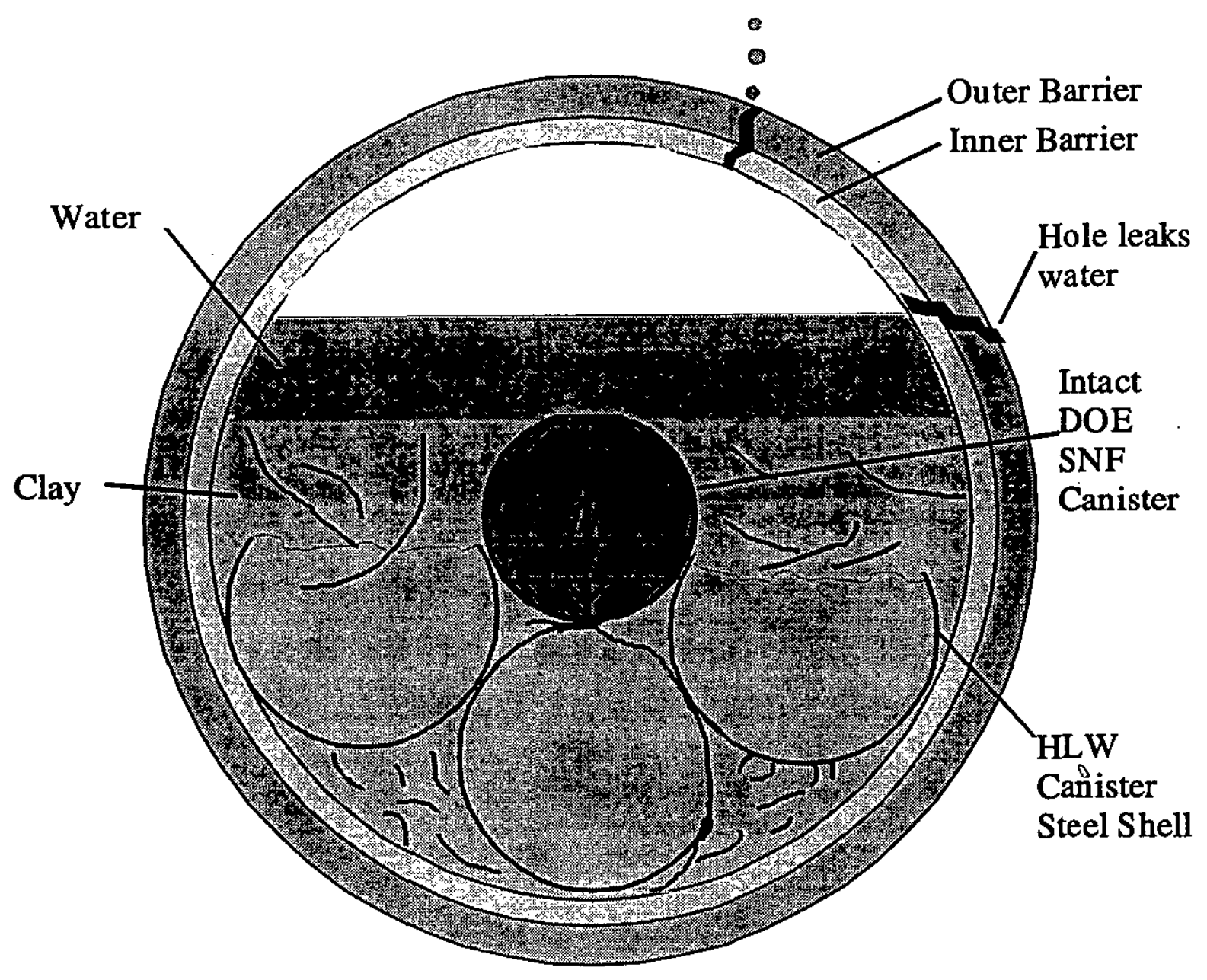

Figure 6.2-4. HLW Glass Completely Degraded; But Some of the HLW Canister Steel Shells Intact and Supporting the Still-Intact DOE SNF Canister 
Evaluation of Codisposal Viability for Aluminum-Clad DOE-Owned Spent Fuel: Phase II - Degraded Codisposal Waste Package Internal Criticality

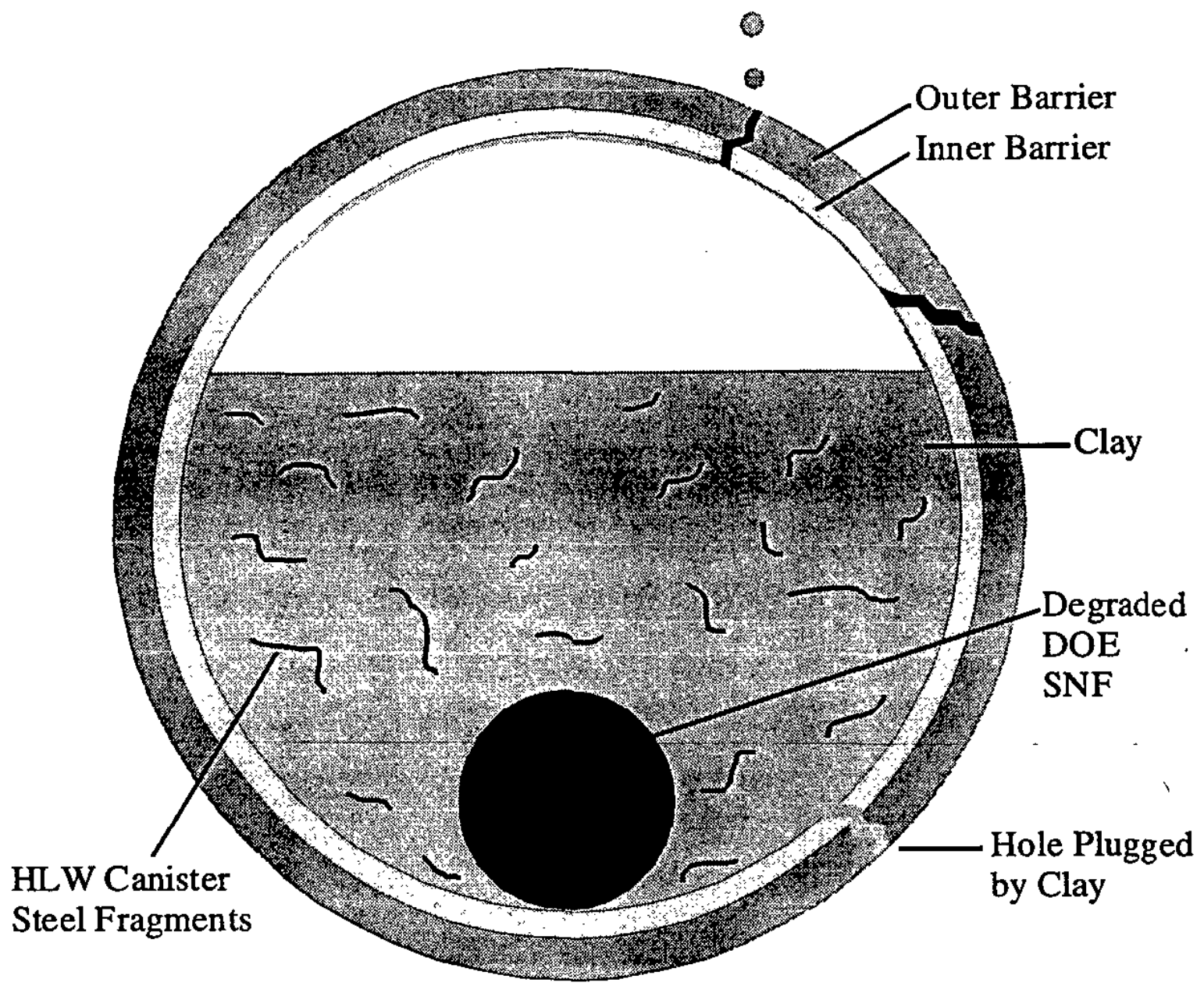

Figure 6.2-5. Further Degradation Following Figure 6.2-4 Configuration; All Steel Shells have Broken, But some Fragments Remain Uncorroded; DOE SNF Canister Breached and Basket Degraded 


\section{Evaluation of Codisposal Viability for Aluminum-Clad DOE-Owned Spent Fuel: Phase II - Degraded Codisposal Waste Package Internal Criticality}

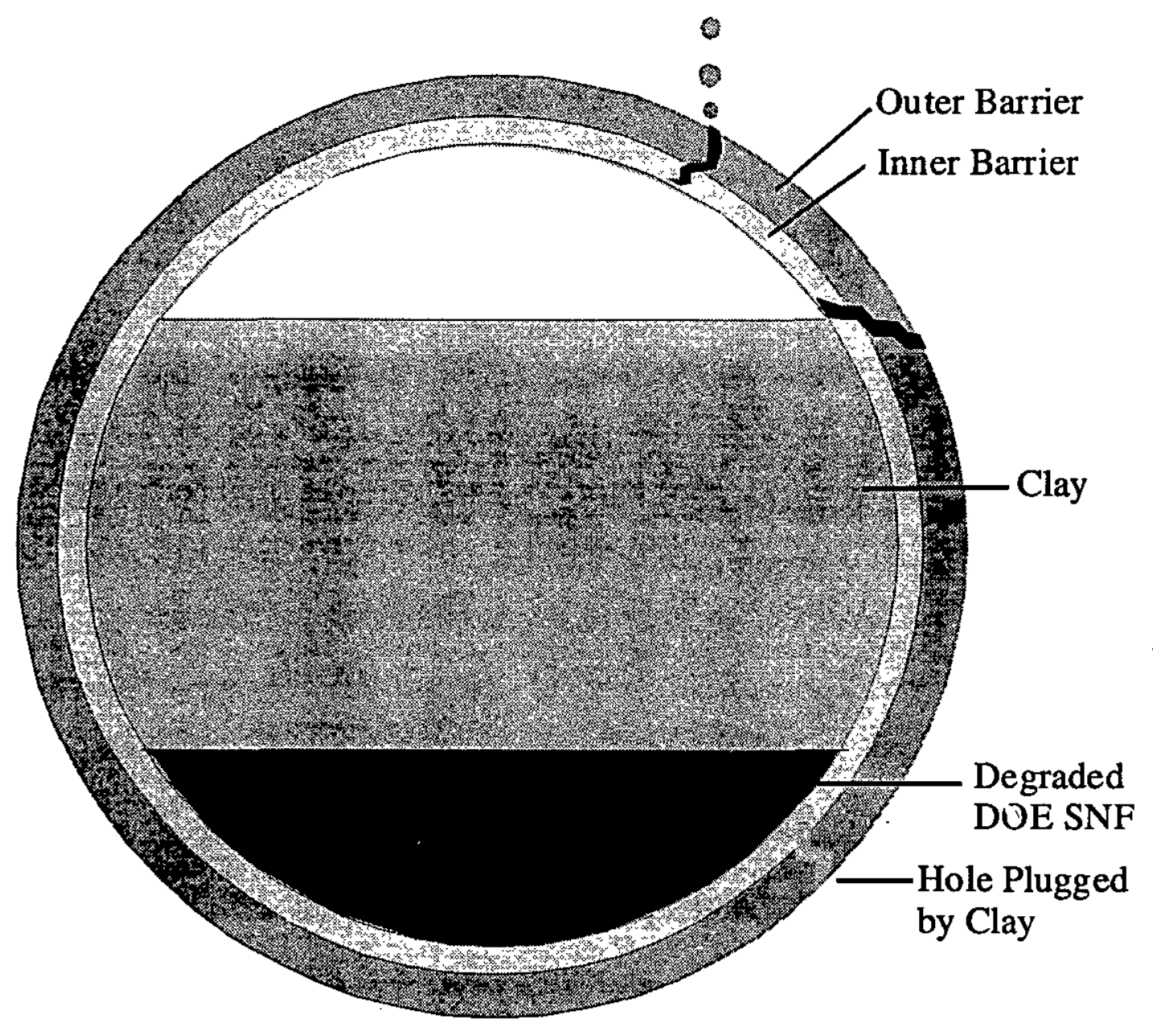

Figure 6.2-6. Further Degradation Following Figure 6.2-5 Configuration; All Canister Contents and Shells have Completely Degraded 
Evaluation of Codisposal Viability for Aluminum-Clad DOE-Owned Spent Fuel: Phase II - Degraded Codisposal Waste Package Internal Criticality

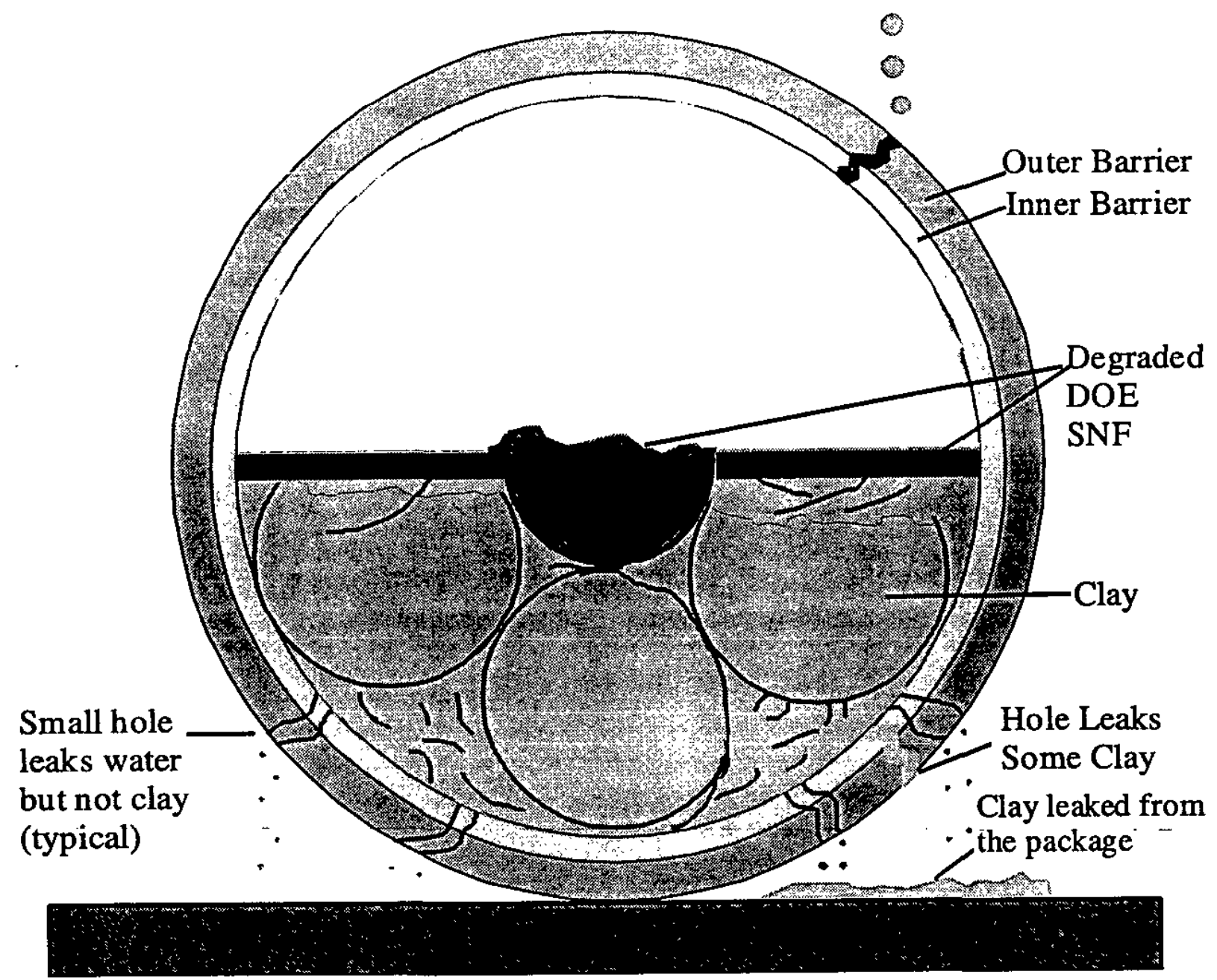

Figure 6.2-7. Further Degradation Following Figure 6.2-4 Configuration; DOE SNF Canister Mostly Degraded but Still Supported on the Steel Shells of HLW Canisters; Holes in the Bottom have Drained Some Clay 
Evaluation of Codisposal Viability for Aluminum-Clad DOE-Owned Spent Fuel:

Phase II - Degraded Codisposal Waste Package Internal Criticality

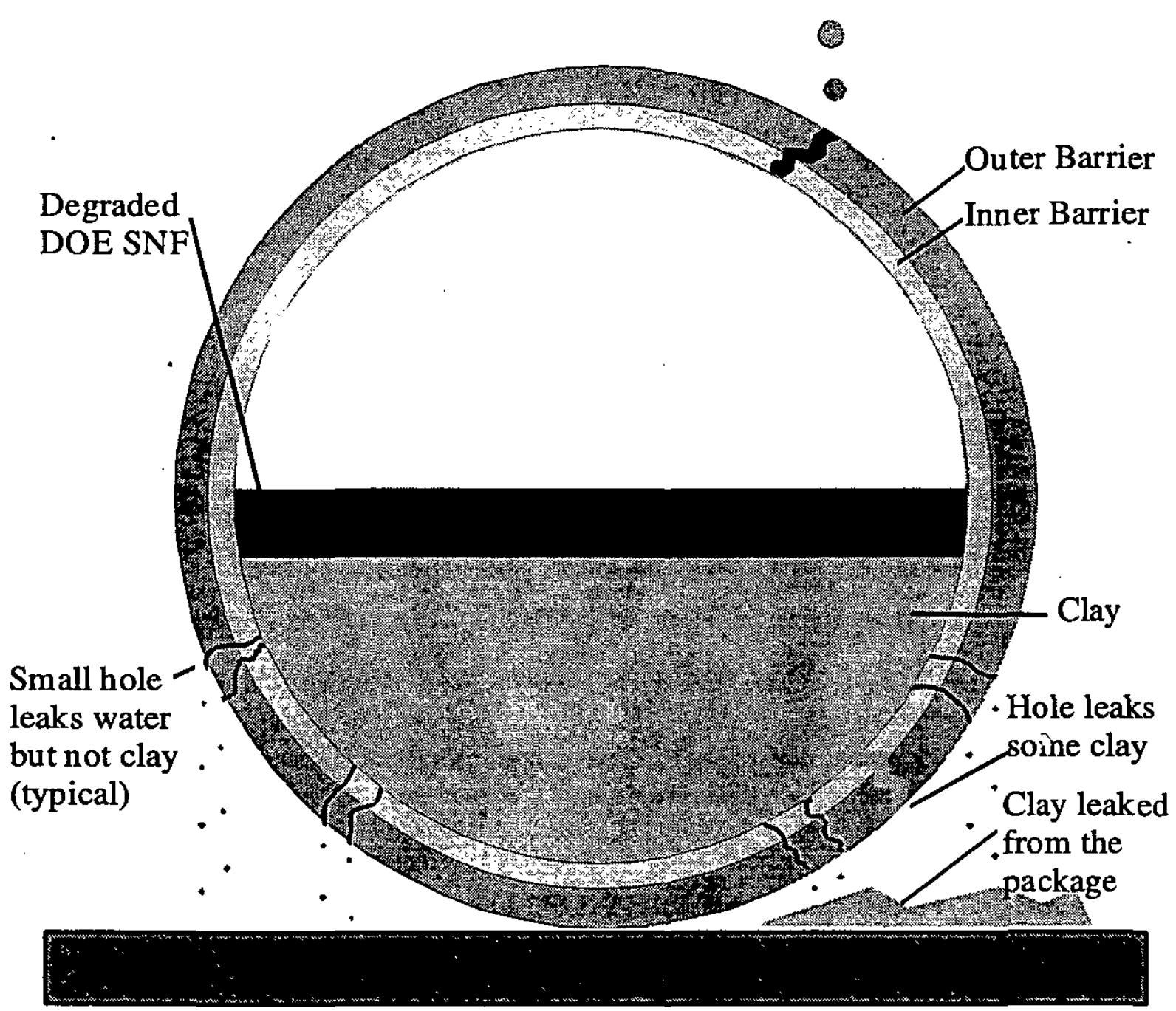

Figure 6.2-8. Further Degradation Following Figure 6.2-7 Configuration; All Canister Contents and Shells have Completely Degraded 
Evaluation of Codisposal Viability for Aluminum-Clad DOE-Owned Spent Fuel:

Phase II - Degraded Codisposal Waste Package Internal Criticality

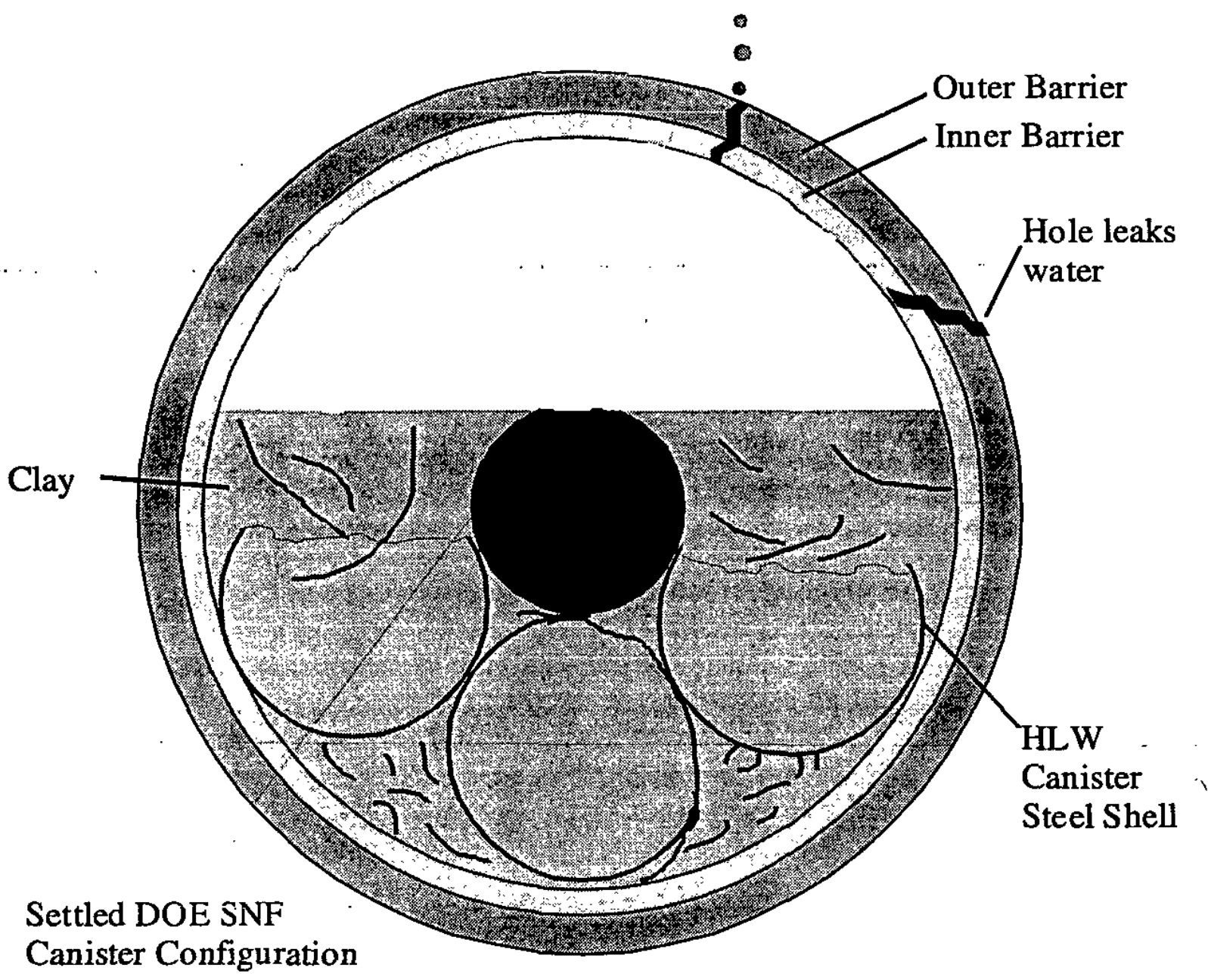

Figure 6.2-9. Extreme Stratification within the DOE SNF Canister: $78 \%$ of ${ }^{235} \mathrm{U}$ in Lower Layer and $22 \%$ in Upper Layer 
Evaluation of Codisposal Viability for Aluminum-Clad DOE-Owned Spent Fuel:
Phase II - Degraded Codisposal Waste Package Internal Criticality

\subsection{Geochemistry Calculations}

The degradation environment is partly determined by several degradation processes which are taking place simultaneously. In particular, the HLW glass degradation products will cause the $\mathrm{pH}$ to increase. If the SNF degrades in a high $\mathrm{pH}$ environment, most of the released uranium could go directly into solution. In contrast, when the SNF degrades in a near-neutral pH environment (characteristic of inflowing J-13 water) most of the released uranium will convert directly into precipitated solids. To provide some guidance in determining the appropriate environment, the estimated periods of degradation for the various basket materials, which were used for most of the computer simulations, are given in Table 6.3-1. References for the data are given in reference 34 .

Table 6.3-1. Typical Corrosion Periods/Lifetimes of Materials which Affect Criticality

\begin{tabular}{|c|c|c|c|c|c|}
\hline Material & $\begin{array}{c}\text { Volume, } \\
\mathrm{cm}^{3}\end{array}$ & $\begin{array}{c}\text { Mass, } \\
\mathrm{g}\end{array}$ & $\begin{array}{c}\text { Surface Area, } \\
\mathrm{cm}^{2}\end{array}$ & $\begin{array}{c}\text { Degradation } \\
\text { Rate, } \\
\mathrm{gm} / \mathrm{cm}^{2} / \mathrm{sec}\end{array}$ & $\begin{array}{c}\text { Duration of } \\
\text { Degradation, } \\
\text { years since } \\
\text { exposure }\end{array}$ \\
\hline $316 \mathrm{SS}$ & $6.68 \mathrm{e}+04$ & $5.31 \mathrm{e}+05$ & $1.62 \mathrm{e}+05$ & $2.52 \mathrm{e}-12$ & $4.12 \mathrm{e}+04$ \\
\hline XM-19 & $6.05 \mathrm{e}+04$ & $4.77 \mathrm{e}+05$ & $7.00 \mathrm{e}+04$ & $3.76 \mathrm{e}-12$ & $5.74 \mathrm{e}+04$ \\
\hline Al & $4.04 \mathrm{e}+04$ & $1.09 \mathrm{e}+05$ & $3.65 \mathrm{e}+04$ & $5.81 \mathrm{e}-09$ & $1.63 \mathrm{e}+01$ \\
\hline Fuel matrix & $2.34 \mathrm{e}+04$ & $5.12 \mathrm{e}+04$ & $6.23 \mathrm{e}+05$ & $2.60 \mathrm{e}-10$ & $1.00 \mathrm{e}+01$ \\
\hline $304 \mathrm{~L}$ & $3.66 \mathrm{e}+05$ & $2.89 \mathrm{e}+06$ & $4.54 \mathrm{e}+05$ & $3.76 \mathrm{e}-12$ & $5.36 \mathrm{e}+04$ \\
\hline Alloy 625 & $4.05 \mathrm{e}+05$ & $3.42 \mathrm{e}+06$ & $1.88 \mathrm{e}+05$ & $2.66 \mathrm{e}-13$ & $2.16 \mathrm{e}+06$ \\
\hline Borated & $1.37 \mathrm{e}+04$ & $1.06 \mathrm{e}+05$ & $6.74 \mathrm{e}+04$ & $1.97 \mathrm{e}-11$ & $2.53 \mathrm{e}+03$ \\
\hline stainless steel & & & & & \\
\hline A516 steel & $1.37 \mathrm{e}+04$ & $1.06 \mathrm{e}+05$ & $6.74 \mathrm{e}+04$ & $5.52 \mathrm{e}-10$ & $9.03 \mathrm{e}+01$ \\
\hline HLW glass & $2.42 \mathrm{e}+06$ & $6.89 \mathrm{e}+06$ & $5.65 \mathrm{e}+06$ & $3.23 \mathrm{e}-11$ & $1.20 \mathrm{e}+03$ \\
\hline HLW glass & $2.42 \mathrm{e}+06$ & $6.89 \mathrm{e}+06$ & $5.65 \mathrm{e}+06$ & $2.31 \mathrm{e}-13$ & $1.67 \mathrm{e}+05$ \\
\hline
\end{tabular}

For the geochemistry calculations it was assumed that, following breach of the outer barriers, the waste package is completely filled with water resembling that in well $\mathrm{J}$-13 (Assumption 4.3.1 of reference 34). For some of the early scenarios shown in Section 6.2, which show some of the material uncovered, this represents a conservative simplification.

This assumption implies the further assumption that the water dripping into the waste package will not have been significantly influenced by interaction with the drift liner (Assumption 4.3.15). 


\section{Evaluation of Codisposal Viability for Aluminum-Clad DOE-Owned Spent Fuel:}

Phase II - Degraded Codisposal Waste Package Internal Criticality

\subsubsection{Degradation of the HLW Glass}

The water chemistry and degradation products generated during the HLW degradation phase were estimated with EQ6; the details are reported in reference 34. As indicated in Table 6.3-1, the duration of this degradation phase will be upwards of 1200 years, depending on the number of HLW canisters which are wetted simultaneously, and on the long-term dissoiution rate of the HLW glass. The most immediately important parameter of this degradation period is $\mathrm{pH}$, which the EQ6 modeling shows to have a time average ranging from 9.7 to 10.0 , for drip rates ranging from 10.0 to $0.1 \mathrm{~mm} / \mathrm{yr}$. For these nominal runs, the partial pressure of $\mathrm{CO}_{2}$ was taken to be atmospheric. For reasons given in reference 34, Assumption 4.3.12, uncertainty surrounding this parameter would permit partial pressures of $\mathrm{CO}_{2}$ ten times atmospheric, which would lead to the slightly lower average $\mathrm{pH}$ range of 9.2 to 9.6 .

The range of drip rates used here is the same as the range of infiltration rates given in TSPA-95 (reference 16); the range is lower than that given in the CDA (reference 20). The justification for this choice is given in Assumption 4.3.14, together with an explanation of the difference between drip rate and infiltration rate.

For purposes of verifying the general results the EQ6 calculations, it should be noted that the indicated EQ6 outputs for the degradation of HLW glass indicate the production mostly of smectite clays, whereas the experiments show clay and other silicate minerals forming after a considerable (a few years) initial delay. This comparison shows that the modeled and experimental results (see reference 34 ) differ only in respect to the model predicting immediate precipitation of secondary phases and the experiments finding a few years delay in the formation of very similar products. The differences in the products are small; in other words, the same elements are predicted to precipitate, and in nearly the same proportions. In the time frames of interest to the present analysis, a delay of a few years in the beginning of precipitation, as compared to model results, is of no consequence. This result is found to be relatively independent of whether degradation of the SNF is taking place simultaneously or following the degradation of the HLW and its corrosion products. This accords with expectations, since the SNF degradation products are only a small fraction of that of the HLW.

The geochemical simulation predicts the precipitation of much of the boron released from the glass as borax, which is well known to be moderately soluble in water. To evaluate the reliability of the simulation with respect to boron, a separate case was run for just solid borax plus pure water for comparison with the measured solubilities for this mineral. This yielded calculated results within $35 \%$ of the reported experimental results which was considered reasonable agreement given the uncertainty in activity coefficients (reference 34).

\subsubsection{Degradation Products of Aluminum and Uranium Aluminide}

The following is a summary of the discussion in reference 34 , Section 6.1 , relating to the validation of the EQ6 methodology for the degradation of aluminum containing solids. Experiments summarized in reference 35 show that, in tests lasting up to 400 hours, alkali feldspars (a common aluminum-containing mineral) first degrade to a gelatinous alumina layer, followed by crystallization to gibbsite and later to halloysite in presence of the silica released 


\section{Evaluation of Codisposal Viability for Aluminum-Clad DOE-Owned Spent Fuel: Phase II - Degraded Codisposal Waste Package Internal Criticality}

from the feldspar. These results lead to the conclusion that aluminum in the presence of J-13 water, which is high in silica, will produce crystalline hydroxides or oxides of aluminum or some clay mineral, as is appropriate to the chemistry of the system. The computer simulations show that initially most of the aluminum degrades to a smectite clay.

\subsubsection{SNF Degradation in a High pH Environment: Removal of Uranium and Boron}

The modeling results indicate that the uranium for this case initially precipitates primarily as the mineral soddyite, $\left(\mathrm{UO}_{2}\right)_{2} \mathrm{SiO}_{4} \cdot 2 \mathrm{H}_{2} \mathrm{O}$. At high $\mathrm{pH}$, the uranium subsequently dissolves as a uranyl carbonate complex and is flushed from the waste package. This simple observation ... results from by EQ6 calculations described in detail in reference 34. These are summarized in Table 6.3-2, which shows the time history of both uranium and boron concentrations in the waste package for a drip rate of $5 \mathrm{~mm} / \mathrm{yr}$. The calculations are also based on a fuel dissolution rate consistent with a lifetime of 10 years (Assumption 4.3.10). Decreasing the fuel dissolution rate by as much as a factor of 50 would not change the overall results significantly. Most of both the uranium and boron come from the HLW glass.

Table 6.3-2. Selected Time History for Simultaneous Degradation of SNF and HLW (Initially High pH Environment)

\begin{tabular}{|c|c|c|c|c|c|c|c|}
\hline $\begin{array}{c}\text { Time, } \\
\text { yrs }\end{array}$ & $\mathrm{pH}$ & $\begin{array}{c}\text { Total U in } \\
\text { Solution, kg }\end{array}$ & $\begin{array}{c}{ }^{235} \mathrm{U} \text { in } \\
\text { Solution, } \mathrm{kg}\end{array}$ & $\begin{array}{c}\text { Total U } \\
\text { in WP, } \mathrm{kg}\end{array}$ & $\begin{array}{c}{ }^{235} \mathrm{U} \text { in WP, } \\
\mathrm{kg}\end{array}$ & $\begin{array}{c}\text { Boron in } \\
\text { Solution, } \mathrm{kg}\end{array}$ & $\begin{array}{c}\text { Boron, Total in } \\
\text { WP, } \mathrm{kg}\end{array}$ \\
\hline 0 & 7.6 & Trace & 0 & 162 & 35.5 & Trace & 221 \\
\hline 12.5 & 9.2 & 2.3 & 2.3 & 162 & 35.3 & 2.1 & 221 \\
\hline 310 & 9.2 & 27.6 & 14.3 & 122 & 14.3 & 3.6 & 210 \\
\hline 1001 & 9.9 & 13.5 & 3.38 & 34.2 & 3.4 & 7.3 & 177 \\
\hline 1207 & 9.9 & 12.3 & 2.69 & 12.3 & 2.7 & 6.7 & 166 \\
\hline 1999 & 8.8 & 0.03 & $5.6 \mathrm{E}-03$ & $2.6 \mathrm{E}-02$ & $5.6 \mathrm{E}-03$ & 6.8 & 125 \\
\hline 2996 & 8.8 & $1.1 \mathrm{E}-05$ & $2.4 \mathrm{E}-06$ & $1.1 \mathrm{E}-05$ & $2.4 \mathrm{E}-06$ & 7.2 & 67 \\
\hline 4008 & 8.8 & $4.3 \mathrm{E}-09$ & $9.4 \mathrm{E}-10$ & $4.3 \mathrm{E}-09$ & $9.4 \mathrm{E}-10$ & 6.3 & 7.4 \\
\hline 5006 & 7.8 & $1.9 \mathrm{E}-12$ & $4.2 \mathrm{E}-13$ & $1.9 \mathrm{E}-12$ & $4.2 \mathrm{E}-13$ & $3.4 \mathrm{E}-03$ & $3.4 \mathrm{E}-03$ \\
\hline 6003 & 7.6 & $8.6 \mathrm{E}-16$ & $1.9 \mathrm{E}-16$ & $8.6 \mathrm{E}-16$ & $1.9 \mathrm{E}-16$ & $3.9 \mathrm{E}-04$ & $3.9 \mathrm{E}-04$ \\
\hline
\end{tabular}

The following observations from these results are significant:

- The high $\mathrm{pH}$ phase is seen to last 1207 years, which corresponds to the minimum duration of the HLW glass degradation phase, as discussed in Section 6.3.1.

- Most of the uranium released from the waste initially precipitates as soddyite, which has redissolved by 310 years.

- The degradation of the HLW glass will release boron at a rate which initially overloads the solubility so much of it will precipitate as borax, but most of the borax will redissolve by 3992 years.

- Most of the boron in the waste package is from the HLW glass (borosilicate). Only $1.37 \mathrm{~kg}$ is 


\section{Evaluation of Codisposal Viability for Aluminum-Clad DOE-Owned Spent Fuel: Phase II - Degraded Codisposal Waste Package Internal Criticality}

contributed by borated stainless steel.

- Almost all of the boron is gone at 5000 years; the boron from the borated stainless steel has been removed before 2996 years, but at only $1.37 \mathrm{~kg}$ total, it is too small to notice. A more specific view of the effects of borated stainless steel degradation is given in Table 6.3-3.

- At 4008 years, nearly all the boron left in the waste package is in solution, only waiting to be flushed out by the very slow drip rate $(0.1 \mathrm{~mm} / \mathrm{yr})$. At 5006 years all the remaining boron is in solution.

\subsubsection{SNF Degradation in a Neutral pH Environment: Removal of Gd}

In this scenario, the uranium will be insoluble and remain in the DOE SNF canister or in the waste package. Initially the uranium precipitates out as $\mathrm{UO}_{3} \cdot 2 \mathrm{H}_{2} \mathrm{O}$ and slowly converts to soddyite as a function of the silicon availability. The principal criticality related chemistry issue is the removal of the neutron absorber. Absorber removal by neutron absorption is not a significant factor in the waste package (Assumption 4.3.17). The removal of criticality control boron has already been touched upon in Section 6.3.2.1 above, and the worst case boron removal will be described in Section 6.7.

This section summarizes the chemistry leading to the possible removal of gadolinium, which has been described in greater detail in reference 34 (Section 7.2.2.2). This possibility arises because one of the principal $\mathrm{Gd}$ containing compounds, $\mathrm{GdCO}_{3}$, is soluble at low $\mathrm{pH}$ (less than 5.8). This condition can be produced by the oxidation of chromium to chromate in the corrosion of stainless steel. If, however, there is sufficient phosphate in the system, $\mathrm{GdPO}_{4}$ will precipitate. This solid is almost completely insoluble at the lowest $\mathrm{pH}$ which could occur in the waste package.

If, on the other hand, there is no phosphate available for combination with the $\mathrm{Gd}$, a pH of 5.8 will result in sufficient solubility of the Gd to permit flushing action to remove most of it from the waste package. This possibility is discussed quantitatively in Section 6.3.4.

\subsubsection{Worst Case Removal of Boron}

Since the high solubility of boron is well known, and since the reliance on borated stainless steel for criticality control is with respect to the slow corrosion of the stainless steel, only a few EQ6 runs were used to verify the rapid removal of the boron after the dissolution of the stainless steel basket. Those cases are described in detail in reference 34 and are summarized in Table 6.3-3 for a drip rate of $5 \mathrm{~mm} / \mathrm{yr}$. The time in this table is with respect to the breach of the waste package, and the time of the first line corresponds to the breach of the DOE SNF canister, which is the start of corrosion of the borated stainless steel. 


\section{Evaluation of Codisposal Viability for Aluminum-Clad DOE-Owned Spent Fuel: Phase II - Degraded Codisposal Waste Package Internal Criticality}

Table 6.3-3. Selected Time History of Boron Concentration in a Codisposal Waste Package Relying on Borated Stainless Steel for Criticality Control

\begin{tabular}{|c|c|c|c|c|c|}
\hline Time, yrs & $\mathrm{pH}$ & $\begin{array}{c}\text { Uranium in } \\
\text { Solution, ppm }\end{array}$ & $\begin{array}{c}\text { Uranium, Total } \\
\text { In WP, } \mathrm{kg}\end{array}$ & $\begin{array}{c}\text { Boron in } \\
\text { Solution, } \mathrm{ppm}\end{array}$ & $\begin{array}{c}\text { Boron, Total } \\
\text { In WP, } \mathrm{kg}\end{array}$ \\
\hline 5755 & 7.75 & $2.1 \mathrm{E}-12$ & 35.5 & $1.4 \mathrm{E}-01$ & 1.37 \\
\hline 5813 & 7.12 & $5.6 \mathrm{E}-03$ & 35.5 & 8.38 & 1.37 \\
\hline 6531 & 6.9 & $3.2 \mathrm{E}-03$ & 35.5 & 22.5 & 1.02 \\
\hline 7502 & 6.9 & $3.0 \mathrm{E}-03$ & 35.5 & 22.8 & 0.47 \\
\hline 8235 & 6.9 & 0.0029 & 35.5 & 22.8 & 0.07 \\
\hline 8337 & 6.9 & 0.003 & 35.5 & 11.3 & 0.03 \\
\hline 8630 & 6.9 & 0.0032 & 35.5 & 1.3 & 0.004 \\
\hline
\end{tabular}

The following observations on these results are significant:

- The small time difference between the first two lines has not permitted the reaction to show significant degradation of the borated stainless steel.

- The amount of boron remaining, $0.07 \mathrm{~kg}$ at 8235 years and $0.004 \mathrm{~kg}$ at 8630 years, decreases to a small fraction of the original inventory.

The relatively rapid decline of the boron concentration with time shows that the borated stainless steel plates are not a completely effective criticality control technique, and that it will be necessary to evaluate less soluble neutron absorbers.

\subsubsection{Worst Case Removal of Gadolinium}

The removal rate of gadolinium depends on its solubility, which in turn depends strongly on the $\mathrm{pH}$ and on certain ionic species that affect the solubility, particularly phosphate, fluoride, and carbonate. Over the $\mathrm{pH}$ range of interest, the $\mathrm{pH}$ strongly influences the concentrations of the free phosphate, $\mathrm{PO}_{4}^{-}$, and carbonate, $\mathrm{CO}_{3}^{-}$, i.e., phosphate or carbonate not bound to hydrogen or other ions as in $\mathrm{HPO}_{4}^{-}$and $\mathrm{HCO}_{3}^{-}$. The following subsections show how the presence of sufficient phosphate will effect the solubility of Gd, and its long-term removal from the waste package.

\subsubsection{Gadolinium Added as $\mathrm{Gd}_{2} \mathrm{O}_{3}$}

The simplest form for adding $\mathrm{Gd}$ is as $\mathrm{Gd}_{2} \mathrm{O}_{3}$. This form of $\mathrm{Gd}$ has been used as the neutron absorber material in the NRC licensed MCC fuel shipping container for VVER-1000 fuel assemblies (reference 36). In that container, the $\mathrm{Gd}_{2} \mathrm{O}_{3}$ was incorporated into an industrial cermet coating (similar to porcelain) applied to a carbon steel base. However, this form of $\mathrm{Gd}$ must still be evaluated with respect to long term Gd solubility. The EQ6 analyses of this issue given in reference 34 show that under conditions of low $\mathrm{pH}(5.8)$, the amount of $\mathrm{Gd}$ retained in the waste package over the long term will be proportional to the amount of phosphate available to react with Gd. In particular, it is shown in Table 7.3-2 of reference 34 that even a few hundred 


\section{Evaluation of Codisposal Viability for Aluminum-Clad DOE-Owned Spent Fuel: Phase II - Degraded Codisposal Waste Package Internal Criticality}

grams of phosphate available to react with the $\mathrm{Gd}$, when added to the phosphate naturally present in the J-13 water, will be sufficient to maintain over 300 grams of $\mathrm{Gd}$ in the waste package for more than 60,000 years (provided the drip rate is only $0.1 \mathrm{~mm} / \mathrm{yr}$ ). Since 60,000 years is the maximum likely duration of stainless steel corrosion, which is also the duration of any acidic water caused by the complete chromate oxidation mechanism, the few hundred grams of phosphate will keep a like amount of Gd insoluble indefinitely.

However, there are several reasons why this amount of natural phosphate will be insufficient to retain the required amount of $\mathrm{Gd}$ :

- If the drip rate is significantly greater than $0.1 \mathrm{~mm} / \mathrm{yr}$, even the relatively small solubility of the Gd will permit flushing much of the Gd required for criticality control before the end of the stainless steel corrosion period.

- If the phosphate present in HLW glass and in steel forms some insoluble compound immediately upon degradation of those forms, it will be unable to react with the Gd to form insoluble $\mathrm{GdPO}_{4}$.

- Even if the phosphate released from HLW glass or steel becomes soluble, it may be flushed from the waste package before it can react with the $\mathrm{Gd}$.

If the phosphate form of $\mathrm{Gd}$ is used for implementing criticality control in the DOE SNF canister, the problem of possible loss from the waste package will not arise, as is explained in Section 6.3.4.2. Possibilities for incorporating $\mathrm{GdPO}_{4}$ into a WP canister might include replacing other absorbers (boron carbide, for instance) in materials, depositing it in a ceramic form on a metal substrate, or as glass beads. These methods have not undergone any analysis or testing

\subsubsection{Gadolinium Added as $\mathrm{GdPO}_{4}$}

The EQ6 cases with Gd added as phosphate, rather than as oxide, are summarized-in reference 34, Section 7.3.2.2. Even at $\mathrm{pH}=5.79$ the solubility of $\mathrm{Gd}$ in the presence of solid $\mathrm{GdPO}_{4}$ is only $0.2 \times 10^{-4} \mathrm{ppm}\left(8.479 \times 10^{-5} \mathrm{~g}\right.$ in WP volume). At the relatively high drip rate of $10 \mathrm{~mm} / \mathrm{yr}$, there can be 15 waste package flushings in 1000 years, so it will take $1000 /\left(15 \times 8.479 \times 10^{-5}\right)=$ $\sim 786,000$ years to remove only 1 gram of Gd. Therefore, it will take over 2 million years to remove a significant amount of $\mathrm{Gd}$ from the waste package. This estimate of $\mathrm{Gd}$ loss is consistent with the EQ6 case reported in Table 7.3-3 of reference 34, which shows much less than 0.1 gram Gd loss in 70,000 years at a drip rate of $0.1 \mathrm{~mm} / \mathrm{yr}$.

This low solubility of $\mathrm{GdPO}_{4}$ is consistent with the natural occurrences of the rare earth phosphates, monazite, and xenotime, which are widely distributed in small amounts in many rocks, and indicates that $\mathrm{GdPO}_{4}$, once formed, will not quickly be dissolved and transported in natural waters. This greatly bolsters confidence that this form of $\mathrm{Gd}$, if added to a waste package, will persist for many thousands of years. The light rare earths are more concentrated in monazite and the heavy ones more concentrated in xenotime. Both minerals survive for very long times during weathering and erosion as evidenced by their presence in river and beach sands, some reaching concentrations sufficient to serve as ores for the rare earth elements | (reference 37, pp. 690-691 and 694-695). This is consistent with their very low solubilities and their persistence as predicted by the EQ6 modeling. 


\section{Evaluation of Codisposal Viability for Aluminum-Clad DOE-Owned Spent Fuel: Phase II - Degraded Codisposal Waste Package Internal Criticality}

\subsubsection{Degradation Products of Uranium Silicide}

The Oak Ridge Research reactor uses uranium silicide as the nuclear fuel. No corrosion rates for uranium silicide are available in the literature. In the absence of such information, and maintaining consistency with thermodynamic stabilities, it was assumed that the silicide would corrode at a rate approximating that for aluminum metal (Assumption 4.3.7 of reference 34). The uranium would react in a similar manner to uranium released from the uranium aluminide, specifically to form soddyite or some other uranyl silicate. Therefore, the uranium from the uranium silicide was modeled by the simulations for the uranium aluminide compound. The silicon would oxidize to the tetravalent state and largely precipitate as insoluble silica minerals, such as quartz or chalcedony, and silicates. The amount of silicon in the fuel is small compared to the silica already in the system, arising from the HLW glass and from the rather high concentration in the J-13 water. Thus, in this case, the relevant scenario was effectively bounded by the simulations for the uranium aluminide. The mass of uranium from the uranium silicide is greater than from the uranium aluminide fuel material but the total fissile content is less. Thus, precipitated fissile material will be diluted by the larger amount of co-precipitated uranium compared to the uranium aluminide simulations. Consequently, no further modeling was required for this fuel and none was performed.

\subsubsection{Summary of Geochemistry Results for Borated Stainless Steel Neutron Absorber}

The geochemistry analyses for the alternatives using borated stainless steel as the criticality control material are summarized in Table 6.3-4.

Table 6.3-4. Summary of Geochemistry Results for DOE SNF Canister Using Borated Stainless Steel Absorber

\begin{tabular}{|c|c|c|c|c|}
\hline & \multicolumn{2}{|c|}{ Removal of U from WP } & \multicolumn{2}{|c|}{ Removal of B from WP } \\
\hline 4 & $\begin{array}{c}\text { Time } \\
\text { Required } \\
\text { Since WP } \\
\text { Breach, } \\
\text { yrs } \\
\end{array}$ & $\begin{array}{c}\text { Cumulative } \\
\text { Water } \\
\text { Through WP, } \\
\mathrm{m}^{3}\end{array}$ & $\begin{array}{c}\text { Time } \\
\text { Required } \\
\text { Since WP } \\
\text { Breach, } \\
\text { yrs } \\
\end{array}$ & $\begin{array}{l}\text { Cumulative } \\
\text { Water } \\
\text { Through WP, } \\
\mathrm{m}^{3}\end{array}$ \\
\hline $\begin{array}{l}\text { Degradation of DOE SNF during } \\
\text { degradation of HLW Glass, } \\
\text { Degrading HLW Interacts with DOE } \\
\text { SNF, Borated Stainless Steel Absorber, } \\
5 \mathrm{~mm} / \mathrm{yr} \text { drip rate. }\end{array}$ & 2000 & 54 & 5000 & 134 \\
\hline $\begin{array}{l}\text { DOE SNF degrades after HLW Glass, } \\
\text { Degraded HLW Interacts with DOE } \\
\text { SNF, Borated Stainless Steel Absorber, } \\
5 \mathrm{~mm} / \mathrm{yr} \text { drip rate. }\end{array}$ & \multicolumn{2}{|c|}{$\begin{array}{c}\text { Most Remains as Soddyite } \\
\text { at } 100,000 \text { years }\end{array}$} & 8000 & 189 \\
\hline
\end{tabular}

If the degrading DOE SNF is exposed to the high pH solution produced while the HLW glass is degrading, the uranium may be removed from the waste package within 2000 years following 


\section{Evaluation of Codisposal Viability for Aluminum-Clad DOE-Owned Spent Fuel: Phase II - Degraded Codisposal Waste Package Internal Criticality}

breach of the waste package (allowing for breach of the DOE SNF canister within 1000 years following breach of the waste package).

\subsubsection{Summary of Geochemistry Results for Gd Neutron Absorber and Recommended Materials}

The gadolinium geochemistry results also have material selection implications. Unlike boron, | gadolinium is basically insoluble, except for $\mathrm{pH}<6$ or $\mathrm{pH}>12$. Therefore, the corrosion resistant properties of stainless steel are not required and the benefits of carbon steel would make it the preferred alternative, not only for carrying the criticality control material (gadolinium), but also for the structural basket. The principal benefits of carbon steel in this regard are the following:

1) carbon steel A516 has a significantly higher yield strength than stainless steel $304 \mathrm{~L}$ or 316 (206 MPa vs $172 \mathrm{MPa}$, references 38 and 39), providing extra safety margins.

2) carbon steel will yield a more uniform spatial distribution of iron oxide, because its faster general corrosion rate will result in more iron oxide being released in the initial basket position, rather than after falling to the bottom in plates, as would stainless steel, and

3) the production rate of iron oxide from the oxidation of carbon steel more nearly corresponds to the release rate of the uranium aluminide from the SNF. 


\section{Evaluation of Codisposal Viability for Aluminum-Clad DOE-Owned Spent Fuel: Phase II - Degraded Codisposal Waste Package Internal Criticality}

Table 6.3-5. Summary of Geochemistry Results for DOE SNF Canister: Removal of Gd Absorber

\begin{tabular}{|c|c|c|}
\hline Scenario & Removal of U from WP & Removal of Gd from WP \\
\hline & $\begin{array}{c}\text { Time Required Since WP } \\
\text { Breach, } \\
\text { yrs }\end{array}$ & $\begin{array}{c}\text { Time Required Since WP } \\
\text { Breach, } \\
\text { yrs }\end{array}$ \\
\hline $\begin{array}{l}\text { DOE SNF Degrades after HLW Glass, } \\
\text { Degraded HLW Interacts with DOE } \\
\text { SNF, } \mathrm{Gd}_{2} \mathrm{O}_{3} \text { Absorber, } 0.1 \mathrm{~mm} / \mathrm{yr} \text { drip } \\
\text { rate. }\end{array}$ & $\begin{array}{c}\text { Most Remains as Soddyite } \\
\text { at } 100,000 \text { years }\end{array}$ & $\begin{array}{l}\text { Most Remains as } \mathrm{GdPO}_{4} \\
\text { at } 100,000 \text { years }\end{array}$ \\
\hline $\begin{array}{l}\text { DOE SNF Degrades after HLW Glass, } \\
\text { Degraded } \mathrm{HLW} \text { does not Interact with } \\
\text { DOE SNF, } \mathrm{Gd}_{2} \mathrm{O}_{3} \text { Absorber, } \\
0.1 \mathrm{~mm} / \mathrm{yr} \text { drip rate. }\end{array}$ & $\begin{array}{l}\text { Most Remains as Soddyite } \\
\text { at } 100,000 \text { years }\end{array}$ & $\begin{array}{l}33 \% \text { Remains ( } 22 \% \text { of } \\
\text { Initial as Solids) } \\
\text { at } 60,000 \text { years }\end{array}$ \\
\hline $\begin{array}{l}\text { DOE SNF Degrades after HLW Glass, } \\
\text { Degraded } \mathrm{HLW} \text { does not Interact with } \\
\text { DOE SNF, GdPO }{ }_{4} \text { Absorber, } \\
0.1 \mathrm{~mm} / \mathrm{yr} \text { drip rate. }\end{array}$ & $\begin{array}{c}\text { Most Remains as Soddyite } \\
\text { at } 100,000 \text { years }\end{array}$ & $\begin{array}{c}\text { Most Remains as } \mathrm{GdPO}_{4} \text { at } \\
100,000 \text { years }\end{array}$ \\
\hline $\begin{array}{l}\text { DOE SNF Degrades after HLW Glass, } \\
\text { Degraded } \mathrm{HLW} \text { does not Interact with } \\
\text { DOE SNF, GdPO }{ }_{4} \text { Absorber, } \\
5.0 \mathrm{~mm} / \mathrm{yr} \text { drip rate. }\end{array}$ & $\begin{array}{c}\text { Most Remains as Soddyite } \\
\text { at } 100,000 \text { years }\end{array}$ & $\begin{array}{l}\text { Most Remains as } \mathrm{GdPO}_{4} \text { at } \\
100,000 \text { years }\end{array}$ \\
\hline $\begin{array}{l}\text { DOE SNF Degrades after HLW Glass, } \\
\text { Degraded } \mathrm{HLW} \text { does not Interact with } \\
\text { DOE SNF, GdPO }{ }_{4} \text { Absorber, } \\
50 \mathrm{~mm} / \mathrm{yr} \text { drip rate. }\end{array}$ & $\begin{array}{c}\text { Most Remains as Soddyite } \\
\text { at } 100,000 \text { years }\end{array}$ & $\begin{array}{c}\text { Most Remains as } \mathrm{GdPO}_{4} \text { at } \\
100,000 \text { years }\end{array}$ \\
\hline
\end{tabular}

\subsection{Configurations Having Separation Between Uranium and the Neutron Absorber}

This section will summarize the scenarios and configurations likely to result in the separation of uranium from the neutron absorber material. The separations are with respect to the nominal waste package configuration having the following material locations:

- The bulk of the iron is in the structural basket plates.

- The added neutron absorber, boron or gadolinium, is in plates (which may be borated stainless steel or carbon steel, and which may or may not be part of the structural basket).

- The uranium is uniformly distributed in the water in the DOE SNF canister. This is a worstcase representation of the most likely configuration in which the uranium aluminide particles adhere to the surfaces of the remaining basket material. At the maximum degree of hydration possible for the uranium aluminides, adherence could be equivalent to uniform distribution throughout the water since the aluminides essentially fill the entire basket void space. It is shown in reference 40 that the homogenization throughout the water in the DOE SNF canister is more reactive, with respect to criticality, than is the configuration with the uranium 


\section{Evaluation of Codisposal Viability for Aluminum-Clad DOE-Owned Spent Fuel: Phase II - Degraded Codisposal Waste Package Internal Criticality}

in a narrow layer about the basket plates.

\subsubsection{Separation Mechanisms}

The separations between the uranium from the fuel and the neutron absorber placed in the basket of the DOE SNF canister for criticality control can arise from several mechanisms illustrated by the following:

- The uranium may become soluble and be removed from the waste package. This can only happen if the DOE SNF canister is breached while the HLW glass is degrading and causing a high $\mathrm{pH}$ where the uranium is sufficiently soluble to enable most of it to be flushed out of the waste package by the action of the water which is causing the degradation of the HLW glass. The parameters of this case are summarized in Table 6.3-1. This case cannot lead to criticality within the waste package, and will, therefore, not be considered further in this study. It is however important for the consideration of the possibility of external criticality, and will be evaluated as part of that future study.

- The absorber may become soluble and be removed from the DOE SNF canister (and subsequently from the waste package), leaving the uranium behind. This is particularly likely for boron once it is released by corrosion of its borated stainless steel carrier matrix (as described in Section 6.3.3), but it is also possible for gadolinium to be removed if the $\mathrm{pH}$ becomes low and there is insufficient phosphate to precipitate the bulk of the gadolinium (as described in Section 6.3.4.1). For completeness, the more optimistic possibilities for retention of boron and gadolinium are considered in Sections 6.4.3 and 6.4.4:1, respectively.

- The uranium (which is released by the rapid corrosion of the SNF matrix) can settle to the bottom of the waste package and collect on the lowest available surface, which may be the bottom of the canister for some of the particles, while most of the neutron absorber remains in the undegraded portion of the basket. The maximum amount of separation by this mechanism is discussed in Section 6.4.4.2.

- The uranium may remain distributed throughout the canister while some of the steel breaks from the basket plates (as cutouts caused by pitting corrosion perforating the periphery). This breaking steel could fall into the bottom of the canister together with its complement of gadolinium, thereby taking some of the gadolinium out of the region in which it is most effective in controlling criticality by absorbing neutrons. This mechanism is applied in Section 6.4.4.2.

It should be noted that the neutron absorbers boron and gadolinium represent criticality control alternatives, and it is unlikely that any waste package design would utilize both. Both alternatives rely on the additional criticality control support from the insoluble iron oxide resulting from the corrosion of basket material. This iron oxide criticality control is particularly effective when carbon steel is used as basket material, because carbon steel corrodes much faster than borated stainless steel. 


\section{Evaluation of Codisposal Viability for Aluminum-Clad DOE-Owned Spent Fuel: Phase II - Degraded Codisposal Waste Package Internal Criticality}

\subsubsection{Evaluation of Differential Settling of Solid Particles of Different Densities}

This section is a condensation of the description given in Section 7.4.2 of reference 34, Section 7.4. It presents an application of mineral engineering practice to the question of the circumstances under which mineral particles of different sizes can settle at approximately the same velocity. It would be most desirable to calculate the different settling rates of particles of different density, but this requires a knowledge of the viscosity of the medium. As the uranium aluminide degrades, it will initially produce an aluminous gel, which will have a very high, but unknown, viscosity. Later it would form a more crystalline sediment which would have yet another viscosity, most likely higher. Nevertheless, it is possible to utilize equations for hindered settling, which require only the average densities of the medium and its constituents to determine the size ratio of particles for equal settling rates (references 41 and 42, pp.186-198 and pp. 336342 , respectively). Since both objects have the same settling velocity, the effect of viscosity cancels out.

Specifically, the equation:

$$
\frac{d_{1}}{d_{2}}=\frac{\left(\rho_{2}-\rho_{s}\right)^{1 / 2}}{\left(\rho_{1}-\rho_{s}\right)^{1 / 2}}
$$

(where $d_{1}$ and $d_{2}$ refer to the diameter of particles of types 1 and 2, respectively; $\rho_{1}$ and $\rho_{2}$ refer to the densities of the particles, and $\rho_{s}$ refers to the effective density of the slurry or suspension) gives the ratio of diameters for equal rates of settling of the particles (references 41 and 42, p. 192, equation VIII.31, and p. 338, equation 9.9, respectively). Whereas both the size and shape of the particles that will be produced are unknown, it seems certain that the sizes will be in the colloidal range, in view of the initial production of gelatinous alumina and generally fine grain size of individual particles in rust, and it is assumed that the shapes will be sufficiently similar that the shape effect will be small (Assumption 4.3.24 of reference 34). Details of the calculations are given in Attachment IV of reference 34.

At a water volume fraction of 0.6 with no admixed goethite (which contains the iron), the diameter ratio for gibbsite (which contains the aluminum) versus soddyite (which contains the uranium) is about 2 , and at a volume fraction of 0.9 the diameter ratio is approximately 1.7. With admixed goethite and a water volume fraction of 0.6 , the diameter ratio for gibbsite versus soddyite is about 2.5 and for goethite versus soddyite is about 1.1 ; at a volume fraction of 0.9 these ratios are about 1.1 and about 1.07 , respectively. The implications of these results are that the soddyite would tend to settle faster than gibbsite, thereby producing a modest separation.

However, this would occur early in the degradation and presumably the entire mass would collect on top of steel components of the DOE SNF basket structure. In such a case, the separation is of no importance to criticality because the fissile material would be adjacent to or mixed with the neutron absorber material. If borated stainless steel is used to absorb neutrons, the mass containing the soddyite would settle directly on top of it. If $\mathrm{Gd}_{2} \mathrm{O}_{3}$ is added instead as the absorber, it would settle out somewhat faster (while it was insoluble), because of its higher density, $7.4 \mathrm{~g} / \mathrm{cm}^{3}$ (reference 43 , p. B-113) and thus lie on top of the steel basket structure mixed with or immediately below the soddyite. $\mathrm{GdPO}_{4}$, density about $4.8 \mathrm{~g} / \mathrm{cm}^{3}$ (reference 42 , pp. 413 


\section{Evaluation of Codisposal Viability for Aluminum-Clad DOE-Owned Spent Fuel: Phase II - Degraded Codisposal Waste Package Internal Criticality}

and 679), if added, would also settle somewhat faster than the soddyite directly on the steel, and the rhabdophane, $\mathrm{GdPO}_{4} \cdot \mathrm{H}_{2} \mathrm{O}$ that would likely form from reaction with $\mathrm{Gd}_{2} \mathrm{O}_{3}$, having a density about $4 \mathrm{~g} / \mathrm{cm}^{3}$ (reference 42 , p. 516) would settle at about the same rate as the soddyite. Consequently, any separation that might occur between the degradation products of the aluminum and the fuel would be of no importance to criticality. As degradation of the DOE SNF canister continues with the corrosion of the steel, large quantities of iron oxides and hydroxides would be produced, but, as shown above, the potential for separation from fissile material is small. Moreover, any gadolinium present should remain admixed.

These theoretical arguments are supported by geologic evidence. It is well known in nature that heavy minerals may to some degree become separated from lighter ones to form placer deposits. However, the degree of separation is not extreme in spite of the agitation and suspension in rivers and beaches responsible for the segregation. One might expect the greatest separation from very heavy minerals, such as gold, and much lighter common ones, such as quartz. The respective densities are $17 \mathrm{~g} / \mathrm{cm}^{3}$ (reference 43, p. B-115) and $2.65 \mathrm{~g} / \mathrm{cm}^{3}$ (reference 44, p. 504).

Nevertheless, the percentage of gold in typical placers is very low. Without stream or wave action to promote the differential settling of the gold the degree of concentration would be even less. Moreover, this degree of separation occurs in sands and gravels, not in fine grained materials, such as clays. Apparently, there are no known placer deposits for clay beds or their rock equivalent, shales. Thus, these analogies also argue that the probability of significant separation of the fine grained degradation products in the waste package as a consequence of gravitational settling is extremely low. Specific locations for such geologic deposits are given in reference 34 .

\subsubsection{Worst Case Separation of the Neutron Absorber Boron from Uranium}

The analysis given in this section is a condensation from that given in reference 34 . Calculations based on the assumed corrosion rate for borated stainless steel, and summarized in Table 6.3-1, show that this criticality control material will be completely corroded away in less than 10,000 years. It is expected that most of the boron released from the corrosion of borated stainless steel will be dissolved, because of the high solubility of boron, and this is verified by the EQ6 calculations summarized in Section 6.3.2.1. Because of this possible loss of criticality control material, the criticality control effectiveness of borated stainless steel is questionable.

On the other hand, it is possible for the waste package to degrade in such a way that the borated stainless steel in the DOE SNF canister is not contacted to a significant degree by circulating or flowing water. In such circumstances, the corrosion rate of the borated stainless steel is severely limited. As was shown in Table 6.3-1, the degradation of the HLW glass may occur in approximately 1200 years following breach of the waste package, HLW canister, and initial exposure of the HLW glass to water. However, all the canisters (HLW and codisposal) may not be contacted by water at once, and complete degradation of the HLW glass may take considerably longer.

With respect to the removal of boron, the fraction of the time for which the DOE SNF canister will be contacted by water is of primary importance. To approximate the process by which water dripping on the waste package is converted to flow and circulation through the waste package, it 


\section{Evaluation of Codisposal Viability for Aluminum-Clad DOE-Owned Spent Fuel: Phase II - Degraded Codisposal Waste Package Internal Criticality}

is assumed that the primary direction of the water movement within the waste package is downward, so that probability of a dripping flow contacting a mass within the package will be equal to the fraction of the horizontal cross section area occupied by that mass (Assumption 4.3.13 of reference 34). For the DOE SNF canister this fraction is 0.29.

This probability is not much less than one, and might be further increased by the following consideration. For any given waste package, the occurrence of a drip, and the location of that drip, might be independent of time, or might vary with time. In the latter case, the effect would be to convert the small probability of corrosion of borated stainless steel (0.29) to a certainty, but over a longer period of time. This longer period would be approximated by taking the nominal corrosion time of 2500 years (following breach of the DOE SNF canister) given in Table 6.3-1, and dividing by 0.29 to get 8600 years.

An additional conservative aspect of this analysis is that it neglects other configurations which have even stronger prevention of water contacting the borated stainless steel in the basket of the DOE SNF canister. For example, the configuration in which the clay covering the DOE SNF canister has insufficient permeability to permit any significant water flow over the borated stainless steel.

\subsubsection{Separation of Gadolinium Absorber from Uranium}

As with boron, the principal probability of criticality arises from the removal of gadolinium from the waste package due to solubility. The analysis of Section 6.3.4.1 shows that gadolinium is only soluble at low $(<6)$ or very high $(>12) \mathrm{pH}$, and then only if the amount of phosphate present in the system is severely limited. It is, therefore, useful to summarize the results in terms of the chemical form of the gadolinium used for criticality control.

\subsubsection{Maximum Separation of Gadolinium as $\mathrm{Gd}_{2} \mathrm{O}_{3}$}

The EQ6 simulations described in Section 7.3.2.1 of reference 34 show there is a possibility of low $\mathrm{pH}$ (as a result of complete oxidation of the chromium in stainless steel to chromate), and this low $\mathrm{pH}$ will be associated with a high solubility for gadolinium. In particular, Table 7.3-2 of reference 34 and Section 6.3.4.1 of this document both showed that the amount of gadolinium which is certain to be retained in the system is limited by the amount of phosphate present in the system when the gadolinium is released by the steel. Unless additional phosphate is added, the worst case gadolinium retention could be as low as $337 \mathrm{~g}$. For this reason, the criticality control effectiveness of gadolinium can be said to be questionable.

This section evaluates the less conservative possibility that the solution having $\mathrm{pH}$ lowered by the corroding stainless steel is not in direct contact with the $\mathrm{Gd}_{2} \mathrm{O}_{3}$ inside the DOE SNF canister. This is a summary of the discussion given in of reference 34 (specifically Section 7.4.4.1 and Attachment $\mathrm{V}$ ). If the lowered $\mathrm{pH}$ solution does not contact the $\mathrm{Gd}_{2} \mathrm{O}_{3}$, the $\mathrm{Gd}$ will remain insoluble and not be lost from the waste package. Such a configuration could have the DOE SNF canister lying anywhere between the bottom of the waste package and the surface of the clay (or water), anything between the geometries shown in Figures 6.2-5 and 6.2-7. 


\section{Evaluation of Codisposal Viability for Aluminum-Clad DOE-Owned Spent Fuel: Phase II - Degraded Codisposal Waste Package Internal Criticality}

The probability of the solution from the degrading stainless steel contacting the Gd in the DOE SNF canister (given that water has dripped into, and collected in, the waste package) is the product of the probability that the water will directly contact the DOE SNF canister within the waste package (estimated as 0.29 in Section 6.4 .3 , above), multiplied by the probability that the clay above the DOE SNF canistcr (or its remnant) will contain a significant amount of corroding stainless steel. To estimate this latter probability it is assumed that:

1) the average height of the clay surface above the waste package bottom is uniformly distributed between the diameter of the DOE SNF canister and the diameter of the waste package, and

2) the top of the DOE SNF canister (or that of its remnant) is uniformly distributed between the diameter of the DOE SNF canister and the height of the clay surface.

It is further assumed that the probability of the clay above the DOE SNF canister having a significant amount of corroding steel, is approximated by the ratio of the average depth of the DOE SNF canister divided by the maximum depth (which is the waste package diameter minus the DOE SNF canister diameter). (Assumption 4.3.17 of reference 34) This gives the double integral:

$$
\frac{1}{D-d} \int_{d}^{D} \frac{d H}{(H-d)^{2}} \int_{0}^{H-d} h d h
$$

where $\mathrm{D}$ is the diameter of the waste package and $\mathrm{d}$ is the diameter of the DOE SNF canister. This integral is normalized to (divided by) D-d, to give a value of $=0.25$. Further details of this calculation are given in Attachment $\mathrm{V}$ of reference 34. When this factor is multiplied by the 0.29 calculated earlier, the resulting conditional probability of this process (which is necessary for criticality to occur) is 0.0725 , given the increased dripping on the individual waste package.

As with the analysis of boron removal in Section 6.3.4.1, above, the occurrence of a drip, and the location of that drip, might be independent of time, or might vary with time. In the latter case, the effect would be to convert the small probability of contacting the DOE SNF canister (0.29) to a certainty, but over a longer period of time, which would be approximated by taking the nominal time to lose most of the gadolinium, 60,000 years following breach of the DOE SNF canister given in Table 7.3-2, and dividing by 0.29 to get 210,000 years.

\subsubsection{Maximum Separation of Gadolinium as $\mathrm{GdPO}_{4}$}

It has been shown in Section 6.3.4.2 that gadolinium incorporated as $\mathrm{GdPO}_{4}$ will be sufficiently insoluble that it will remain in the waste package for more than several hundred thousand years. Any internal criticality will require the physical separation of the $\mathrm{GdPO}_{4}$ from the ${ }^{235} \mathrm{U}$. The following two scenarios, which have already been suggested as the last two separation mechanisms described in Section 6.4.1, are presented to represent the opposite extremes for generating a separation of neutron absorber from fissile material while both remain inside the DOE SNF canister: 


\section{Evaluation of Codisposal Viability for Aluminum-Clad DOE-Owned Spent Fuel: Phase II - Degraded Codisposal Waste Package Internal Criticality}

1) a major fraction of the uranium particles settles to the bottom through holes in the remaining basket plates, and

2) a significant fraction of the gadolinium is trapped in the steel cutout from the plates as a result of random pitting corrosion of a periphery for each cutout; these cutouts will settle to the bottom through holes (pits and cutouts) in the remaining basket plates.

For calculation convenience it is assumed that the waste package is oriented such that the large basket plates, shown horizontal in Figure 4.1.3, actually are horizontal and that the disposition of material from the plates which are angled to the large plates (also shown in Figure 4.1.3) will be the same as for the horizontal plates (Assumption 4.3.12).

The following analysis, summarized from Section 7.4.4.2 of reference 34 applies to both scenarios.

The geometry for this analysis is based on the waste package and DOE SNF canister for the highly enriched MIT SNF, shown in Figure 4.1-3. Most of the fuel (75\%) is contained in the volume within the four longest plates of the DOE SNF canister. For purposes of defining the maximum cutout, a random distribution of pits was simulated over the maximum unsupported basket plate span $(15 \mathrm{~cm} \times 60 \mathrm{~cm} \times 0.8 \mathrm{~cm}$ thick, where the $15 \mathrm{~cm}$ width is from the canister wall to the center diagonal brace between the two innermost plates). The pit penetrations at the surface were taken to be $0.8 \mathrm{~cm}$ square cells. This cell size approximates the volume corroded by a pit, by using a cube having dimension equal to the thickness of the basket plate. In this manner, the maximum unsupported plate is divided into a $19 \times 75$ rectangular array, as shown in Figure 7.4-4 of reference 34 . It is assumed that this pit size is appropriate to carbon steel. For sainless steel, it is assumed that the pit cross section area is $1 \%$ of the carbon steel value, giving 100 times as many square cells on the reference basket plate. For conservatism, the basket plates were assumed to be oriented horizontally (Assumption 4.3.9 and Assumption 4.3.12), thus maximizing the available surface area.

Statistics for 100 realizations were generated by use of the cutout analysis program for grid sizes representing both carbon steel $(19 \times 75)$ and stainless steel $(190 \times 750)$. The results are given in Tables 6.4-1a and 6.4-1b. In these tables, Pitfrac is the fraction of the cells that have pits; Cutfrac is the fraction of cells which are in cutouts; Sdcutfrac is the standard deviation of the fraction of cells which are in cutouts (Cutfrac); NumCutout is the number of distinct cutout areas; SDCutout is the standard deviation of NumCutout; Avarea is the average area of a cutout

The rates of aqueous corrosion and dissolution for the various solid forms in the waste package are given in Table 4.1.6-1. The rates for glass are expressed in the standard intrinsic material units, $\mathrm{g} / \mathrm{m}^{2} /$ day. The rates for the various types of steel are expressed in microns per year under the standard assumption that all plates have a thickness much less than length or width. It 


\section{Evaluation of Codisposal Viability for Aluminum-Clad DOE-Owned Spent Fuel: Phase II - Degraded Codisposal Waste Package Internal Criticality}

Table 6.4-1a. Cutout Statistics for a $19 \times 75$ Grid (to model carbon steel)

$\begin{array}{rrrrrr}\text { Pitfrac } & \text { Cutfrac } & \text { SDcutfrac } & \text { NumCutout } & \text { SDCutout } & \text { Avarea } \\ 0.070 & 0.000 & 0.000 & 0 & 0.171 & 2.000 \\ 0.140 & 0.001 & 0.001 & 0 & 0.571 & 1.705 \\ 0.211 & 0.003 & 0.002 & 2 & 1.452 & 1.595 \\ 0.281 & 0.012 & 0.008 & 9 & 2.823 & 2.084 \\ 0.351 & 0.053 & 0.029 & 22 & 4.755 & 3.492 \\ 0.421 & 0.187 & 0.059 & 46 & .6 .157 & 5.765 \\ 0.491 & 0.294 & 0.042 & 80 & 7.782 & 5.262 \\ 0.561 & 0.316 & 0.020 & 113 & 8.610 & 3.981 \\ 0.632 & 0.290 & 0.012 & 140 & 9.350 & 2.942 \\ 0.702 & 0.244 & 0.008 & 152 & 9.678 & 2.285 \\ 0.772 & 0.192 & 0.006 & 143 & 16.596 & 1.906\end{array}$

Table 6.4-1b. Cutout Statistics for a $190 \times 750$ Grid (to model stainless steel)

$\begin{array}{rrrrrr}\text { Pitfrac } & \text { Cutfrac } & \text { SDcutfrac } & \text { NumCutout } & \text { SDCutout } & \text { Avarea } \\ 0.070 & 0.000 & 0.000 & 3 & 1.767 & 1.060 \\ 0.140 & 0.000 & 0.000 & 51 & 6.463 & 1.078 \\ 0.211 & 0.002 & 0.000 & 251 & 15.586 & 1.229 \\ 0.281 & 0.009 & 0.001 & 828 & 26.889 & 1.585 \\ 0.351 & 0.052 & 0.005 & 2225 & 42.202 & 3.298 \\ 0.421 & 0.488 & 0.015 & 4989 & 65.385 & 13.940 \\ 0.491 & 0.484 & 0.002 & 8907 & 82.337 & -7.748 \\ 0.561 & 0.426 & 0.001 & 12998 & 92.380 & 4.668 \\ 0.632 & 0.360 & 0.000 & 16262 & 100.054 & 3.157 \\ 0.702 & 0.293 & 0.000 & 18033 & 99.501 & 2.313 \\ 0.772 & 0.224 & 0.000 & 17820 & 82.777 & 1.794\end{array}$

should, of course, be noted that the times to corrode the stainless steel may be up to 2 orders of magnitude greater than for the carbon steel. Nevertheless, the following comparisons are important:

1) The maximum cutout fraction for stainless steel is significantly greater than for carbon steel, as would be expected from the smaller pit size (finer resolution grid).

2) The maximum cutout fraction for stainless steel occurs at a lower pitting fraction than for carbon steel, increasing the importance of cutouts as a mechanism for removing material.

3) The ratio of standard deviation divided by the corresponding statistic (Cutfrac or NumCutout) is much smaller in Table 6.4-1b than in Table 6.4-1a. This is because the former involve much larger numbers of pits and cutouts, and this ratio is inversely proportional to the square root of the number of items. This ratio is a measure of the fractional error in the process and can be reduced by taking more realizations.

The remainder of this section is devoted to an estimate of the worst case separation of the Gd from the U.

For carbon steel, the percent of Gd trapped in cutouts is estimated to be one half the cutout fraction to account for the fact that by the time the pit penetrates the $0.8 \mathrm{~cm}$ plate thickness, $50 \%$ 


\section{Evaluation of Codisposal Viability for Aluminum-Clad DOE-Owned Spent Fuel: Phase II - Degraded Codisposal Waste Package Internal Criticality}

of the plate thickness will also have been removed by bulk corrosion. The reason for this factor is as follows: the pitting corrosion factor for carbon steel (the carrier metal of choice for the $\mathrm{GdPO}_{4}$ neutron absorber material) is 4 (reference 15 , Section 5.4.4), which means that the pit penetration rate is 4 times the bulk corrosion rate; the bulk corrosion rate is then increased by a factor of 2 to account for corrosion from both surfaces, while the pit can only go from one surface at a time.

This analysis provides a lower bound for the amount of $\mathrm{Gd}$ which will be removed to the bottom; since the Gd precipitate remaining from corrosion of the steel is not significantly hydrated, it is all likely to remain on top of the remaining thickness of uncorroded plate where it will all be available to fall through when the cutout develops. Furthermore, the Gd will not actually be emplaced in the basket structural steel, but rather in thinner plates $(0.25 \mathrm{~cm})$ fastened to the structural basket plates (mostly the horizontal plates of the basket in Figure 4.1.3). Such a thinner plate is likely to be completely corroded before the cutout appears in the plate to which it is attached. All the Gd is likely to be available to fall through any cutout which appears beneath it.

As explained above, the basket was approximated by the 4 largest plates, so that all the fuel is approximated as falling between these plates. Therefore, there are no cutouts or particulates falling through the top plate. Furthermore, the lowest plate approximates the bottom of the canister. Therefore, the probability of settling through the plates was estimated as the average of the probabilities of passing through 2 plates, 1 plate, and zero plates. For this calculation the probabilities of passing through the several numbers of plates is as follows: (1) zero plates, which requires no special conditions so the probability $=1,(2)$ one plate, probability $=$ the sum of the fraction of area covered by pits plus the fraction cutout, and (3) two plates, probability is the square of the one plate pass-through.

This methodology is illustrated in Table 6.4-2, for the largest cutout fractions in Tables 6.4-1a and 6.4-1b (corresponding to Pitfracs 0.561 and 0.421 , respectively). Note that the numbers in Table 6.4-2 are expressed as percentages while the numbers in Table 6.4-1 are expressed as fractions. Typical calculations to obtain the fourth and fifth columns of this table are given in the footnotes to the table, and further details are given in Attachment V of reference 34.

Table 6.4-2. Worst Case (Maximum Cutout) Maximum U which can Settle to the Bottom and Minimum Gd which will Settle to the Bottom

\begin{tabular}{|l|l|l|l|l|}
\hline Material & $\begin{array}{l}\text { \% Basket } \\
\text { Covered by Pits }\end{array}$ & \% Cutout & $\begin{array}{l}\text { Max \% of U } \\
\text { at Bottom* }\end{array}$ & $\begin{array}{l}\text { Min \% of Gd at } \\
\text { Bottom } \dagger\end{array}$ \\
\hline Carbon steel & 56 & 32 & 78 & $14 \ddagger$ \\
\hline Stainless steel & 42 & 49 & 83 & $45 \S$ \\
\hline
\end{tabular}

*For maximum $\mathrm{U}$ at bottom, the minimum $\mathrm{Gd}$ at bottom is sufficient to prevent criticality. $\dagger$ For minimum Gd at bottom, the remaining distributed $\mathrm{Gd}$ will be sufficient to prevent criticality with all the $U$ distributed.

$\ddagger\left(1+f+f^{2}\right)(0.32 / 2) / 3$, where $f=0.56+0.32$

$\S\left(1+f+f^{2}\right)(0.49) / 3$, where $f=0.42+0.49$ 


\section{Evaluation of Codisposal Viability for Aluminum-Clad DOE-Owned Spent Fuel: Phase II - Degraded Codisposal Waste Package Internal Criticality}

This approximation may overestimate the amount of material passing through the plates for the following reasons:

1) The pit holes might not actually be in sufficiently large contiguous groups to permit the passing of a large cutout falling from a plate above, and

2) If the plates are near horizontal, much of the wider plates' cutouts/pits will be over the canister wall, since the lowest plate is narrower. Therefore, much of the material overlying the wider plates will fall on the canister wall, rather than on the lowest plate.

3) In this approximation the package bottom and the lowest plate have been combined, thereby adding the corresponding accumulations, even though they are actually separated.

Observations on the results presented in Table 6.4-2 that are relevant to the definition of worstcase (but still physically realizable) configurations for criticality evaluation are the following:

1) The percentages of elements at the canister bottom ( $4^{\text {th }}$ and $5^{\text {th }}$ columns of the table) imply that the complementary percentage of the total element amount is distributed throughout the canister volume.

2) The maximum percentage of $U$ at the bottom ( $4^{\text {th }}$ column of the table) represents the fraction of the total $U$ that could fall through the holes in the degraded plates. This .. maximum must still be distributed in a layer at the bottom that has a physically reasonable thickness, as is done in reference 46.

3) The minimum percentage of $\mathrm{Gd}\left(5^{\text {th }}\right.$ column of the table) is nominally contained in steel, but could also occur as particulates remaining after the corrosion of the steel.

\subsection{Criticality Calculation Models and Results}

Three major configurations were identified for criticality analysis with MCNP based on the degradation sequences described in Section 6.2 and the compositions described in Section 6.4. The scenario development, geochemistry analysis, and configuration identification provide general guidance for the criticality analysis. The mass of material, but not its volume distribution or location, is identified. Parameters such as the amount of water mixed with solids, the density and volume of fissile or absorber material in clay, etc. are not fixed. The criticality analysis involves parametric analyses of several factors in addition to the general geometry configurations described in the previous section. These parameters include water content, ${ }^{235} \mathrm{U}$ volume distributions, absorber and $\mathrm{Fe}_{2} \mathrm{O}_{3}$ distribution, material and reflector effects, and ${ }^{235} \mathrm{U}$ mass available. The focus is on identifying the optimum conditions within the physical bounds of the parameters to find the highest achievable value of $\mathrm{k}_{\text {eff. }}$. The water content of clays can reach levels as high as $90 \mathrm{wt} \%$ (reference 45, sediments from Lake Huron containing high percentages of clays which provides an upper bound although not necessarily representative of HLW type conditions) which would easily exceed the internal volume of the WP. Criticality analyses of fuel and clay mixtures varied the water content only to the point where the internal WP volume 


\section{Evaluation of Codisposal Viability for Aluminum-Clad DOE-Owned Spent Fuel: Phase II - Degraded Codisposal Waste Package Internal Criticality}

was filled (approximately 28 volume $\%$ water). In these cases, optimum moderation could not be achieved. A complete description of these criticality parametric analyses is provided in reference 46. The results required to identify limiting conditions and margins are presented in this report.

As part of an Engineered Barrier System for the containment of radionuclides, the codisposal waste package $\mathrm{k}_{\text {eff }}$ must not exceed 0.95 during the pre-closure phase. As discussed in Section 4.2 (Criteria), in addition to the $5 \%$ margin in $\mathrm{k}_{\text {eff, }}$ account of the bias and uncertainty must be taken. As discussed in Section 5, the bias and uncertainty is estimated to be $2 \%$ in $\mathrm{k}_{\text {eff. }}$ The calculated $\mathrm{k}_{\text {eff }}$ plus statistical uncertainty, therefore, must be less than 0.93 to meet the preclosure criticality design criteria.

Criticality analyses of the MIT and ORR fuel types requires construction of MCNP4A geometry and material models. The development of the geometry models is summarized below. This analysis is documented with computer program output in reference 46 . The base models were originally developed for the intact analysis documented in the Phase I report (reference 2). The structural materials of the waste package are ASME code materials and are hence well-defined, as is the water moderator (Assumption 4.3.4).

\subsubsection{Degraded MIT SNF Criticality Analysis}

\subsubsection{Homogeneous Mixture of Degraded MIT SNF in DOE SNF Canister}

These configurations consist of a DOE SNF canister situated among $5 \mathrm{HLW}$ canisters (likely configuration at time of breach) or against the inner barrier of the waste package surrouided by the degraded remnants of the HLW glass (clayey material). There are 3 configurations within the DOE SNF canister for this scenario. The first two of these models, which are the more reactive configurations, are shown in Figures 6.5-1 and 6.5-2. The degraded DOE SNF is homogenized within a basket position or within the canister depending on the degree of degradation of the basket. Variations of the conditions outside the DOE SNF canister are run to demonstraie conservatism. The basket is modeled at various stages of degradation and with stainless steel or carbon steel as the material of fabrication. The third configuration is similar to that shown in Figure 6.2-9 and is based on accumulation of most of the degraded $\mathrm{U}-\mathrm{Al}$ in the bottom of the canister with steel fragments.

The first set of calculations is based on degraded MIT SNF in an intact basket where the boron in borated stainless steel has been replaced by various amounts of $\mathrm{Gd}$. The results are listed in Table 6.5.1.1-1. The configuration with degraded fuel filling the basket cells in an intact basket was identified as the most reactive configuration considered in the Phase I report (reference 2).

Table 6.5.1.1-1. Degraded MIT SNF in an Intact Stainless Steel Basket with Gd Absorber

\begin{tabular}{|c|c|c|c|c|}
\hline Case Name & Mass Gd, kg & $\mathrm{H}^{235} \mathrm{U}$ & AENCF*, MeV & $\mathrm{k}_{\text {eff }} \pm 2 \sigma$ \\
\hline mitoz3g & 0.25 & 113 & 0.0210 & $0.9763 \pm 0.0027$ \\
\hline mitoz4g & 0.50 & 113 & 0.0217 & $0.9458 \pm 0.0032$ \\
\hline mitoz2g & 0.75 & 113 & 0.0220 & $0.9294 \pm 0.0027$ \\
\hline
\end{tabular}


Evaluation of Codisposal Viability for Aluminum-Clad DOE-Owned Spent Fuel: Phase II - Degraded Codisposal Waste Package Internal Criticality

\begin{tabular}{|c|c|c|c|c|}
\hline Case Name & Mass Gd, $\mathrm{kg}$ & $\mathrm{H} /{ }^{235} \mathrm{U}$ & AENCF*, MeV & $\mathrm{k}_{\mathrm{eff}} \pm 2 \sigma$ \\
\hline mitoz5g & 1.00 & 113 & 0.0221 & $0.9195 \pm 0.0030$ \\
\hline mitoz6g & 1.50 & 113 & 0.0231 & $0.9020 \pm 0.0024$ \\
\hline
\end{tabular}

*AENCF - Average Energy Of Neutron Causing Fission.

As indicated in Table 6.5.1.1-1, less than $1 \mathrm{~kg}$ of $\mathrm{Gd}$ is required in the intact basket where it is least effective (self-shielded). This DOE SNF canister configuration with $1 \mathrm{~kg}$ of Gd was rerun with the canister positioned at the bottom of the degraded HLW mass against the inner barrier of the waste package to demonstrate reflector effects. The result is a $\mathrm{k}_{\text {eff }}$ of $0.9187 \pm 0.0028$ (m5ghom) which statistically is the same result as that for the configuration among the HLW canisters (mitoz5g).

A case with intact MIT SNF and basket corresponding to case mitbz3 in the Phase I criticality report (reference 2) was run with $1.00 \mathrm{~kg}$ of $\mathrm{Gd}$ rather than $\mathrm{B}$ in the absorber plates to demonstrate the significant subcritical margin for intact fuel. The result is a $\mathrm{k}_{\mathrm{eff}}$ of $0.8148 \pm$ 0.0034 (mitbzg1). The case with borated stainless steel (mitbz3, reference 2) has a value of $\mathrm{k}_{\text {eff }}$ of $0.8101 \pm 0.0029$. 


\section{Evaluation of Codisposal Viability for Aluminum-Clad DOE-Owned Spent Fuel: Phase II - Degraded Codisposal Waste Package Internal Criticality}

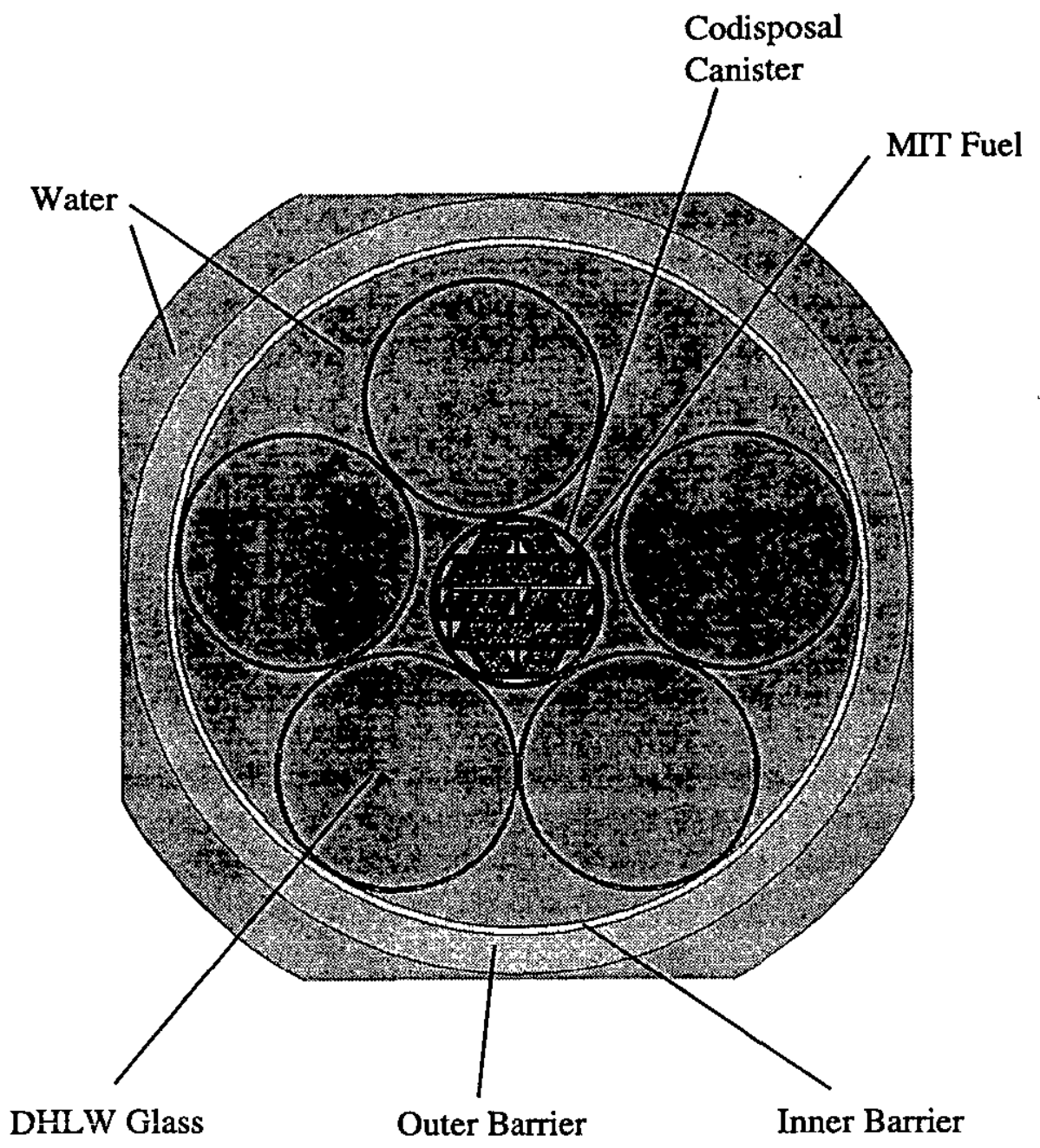

Figure 6.5-1. Degraded MIT SNF in an Intact Basket

In order to demonstrate the effects of replacing stainless steel with carbon steel, four cases were run as listed in Table 6.5.1.1-2. Note that $\mathrm{k}_{\text {eff }}$ increases only slightly for these cases indicating that carbon steel would be an acceptable alternative to stainless steel from a neutronics perspective. 
Evaluation of Codisposal Viability for Aluminum-Clad DOE-Owned Spent Fuel: Phase II - Degraded Codisposal Waste Package Internal Criticality

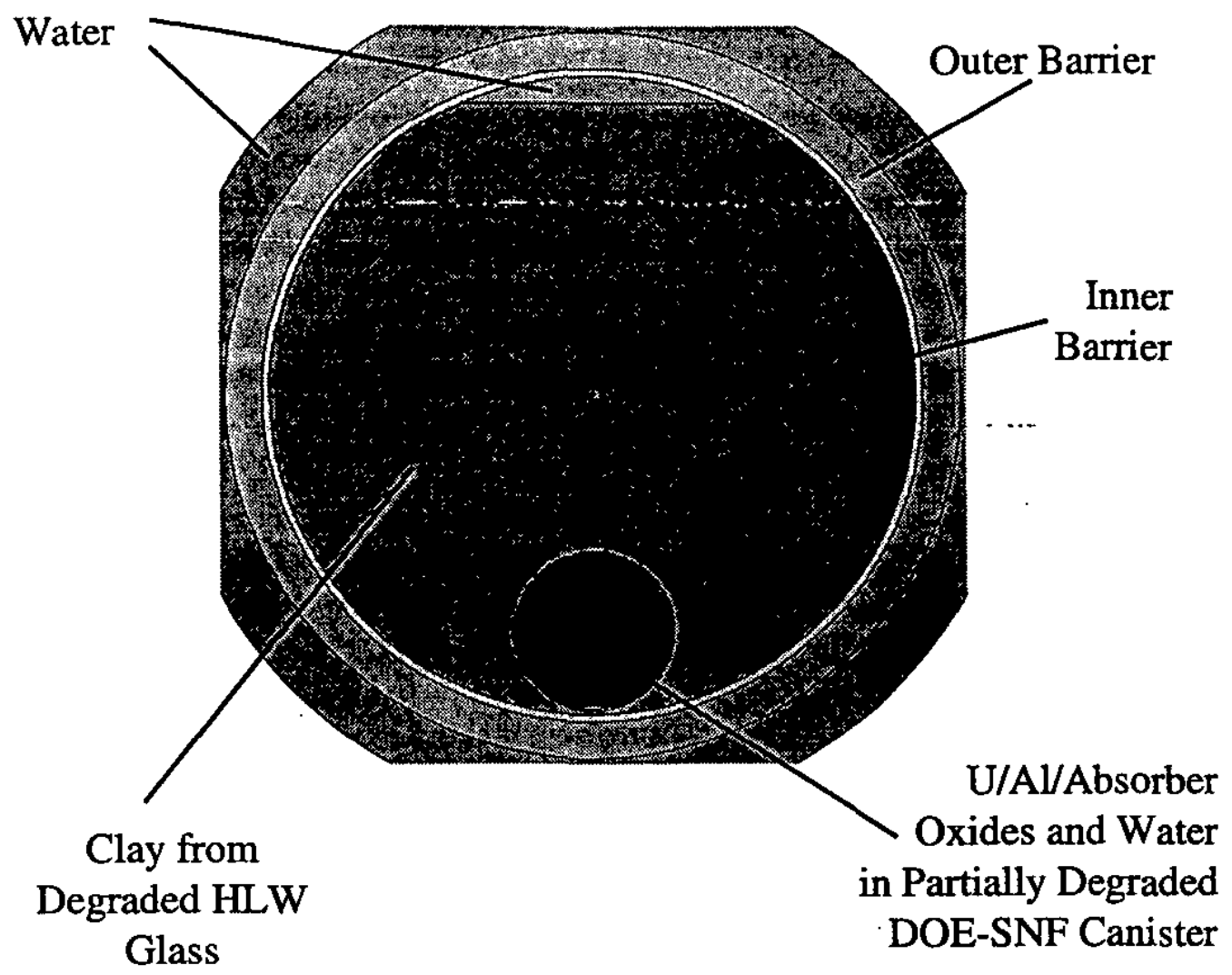

Figure 6.5-2. Homogeneous Mixture of Degraded DOE SNF and Degraded Basket in a DOE SNF Canister

Table 6.5.1.1-2. Check Cases - Carbon Steel Substitution for Stainless Steel in an Intact Basket

\begin{tabular}{|c|c|c|c|c|}
\hline Case Name & Case Descriptions & $\mathrm{H}^{235} \mathrm{U}$ & AENCF*, MeV & $\mathrm{k}_{\text {eff }} \pm 2 \sigma$ \\
\hline mitoz8g & $\begin{array}{c}\text { A516 Absorber Plates, 1.5 } \\
\text { kg Gd }\end{array}$ & 113 & 0.0226 & $0.9062 \pm 0.0031$ \\
\hline mitoz9g & $\begin{array}{c}\text { A516 replacing all stainless } \\
\text { steel in basket, } 1.5 \mathrm{~kg} \text { Gd }\end{array}$ & 113 & 0.0230 & $0.9126 \pm 0.0029$ \\
\hline mitozyg & $\begin{array}{c}\text { A516 replacing all stainless } \\
\text { steel in basket, } 1.25 \mathrm{~kg} \mathrm{Gd}\end{array}$ & 113 & 0.0226 & $0.9216 \pm 0.0029$ \\
\hline mitozxg & $\begin{array}{c}\text { A516 replacing all stainless } \\
\text { steel in basket, } 1.0 \mathrm{~kg} \mathrm{Gd}\end{array}$ & 113 & 0.0219 & $0.9317 \pm 0.0032$ \\
\hline
\end{tabular}

*AENCF - Average Energy Of Neutron Causing Fission.

Analysis of the most reactive degraded fuel mixture in configuration 1 using MCNP indicates that approximately $1 \mathrm{~kg}$ of $\mathrm{Gd}$ is required to be distributed in the MIT fuel intact canister basket if stainless steel is used and $1.25 \mathrm{~kg}$ of $\mathrm{Gd}$, if carbon steel is used. The focus of the calculations in the remaining subsections of Section 6.5 .1 is to demonstrate that, based on the geochemistry analysis, there will always remain mixed with the degraded fuel enough $\mathrm{Fe}_{2} \mathrm{O}_{3}$ and/or $\mathrm{Gd}$ to 


\section{Evaluation of Codisposal Viability for Aluminum-Clad DOE-Owned Spent Fuel: Phase II - Degraded Codisposal Waste Package Internal Criticality}

prevent criticality in the configurations attained after the basket degrades.

The second set of calculations is based on a degraded basket configuration where the MIT SNF is homogenized into the canister volume with various amounts of iron oxide (from the basket) and Gd as illustrated in Figure 6.5-2. The canister wall is modeled as being thinned down to $0.5 \mathrm{~cm}$ thick from the initial thickness of $1.5 \mathrm{~cm}$ to represent a severely degraded state. The HLW clayey material is modeled with $25 \%$ free water fraction that nearly fills the waste package. The results for the degraded basket cases are provided in Table 6.5.1.1-3. The mass of iron oxide produced from the complete oxidation of the stainless steel basket structure in the baseline design corresponds to $590.5 \mathrm{~kg}$ of iron oxide. As discussed in Section 6.4, stainless steel would likely degrade to a mix of stainless steel pieces and iron oxide, with the ratio of pieces to oxide decreasing with time. The basket would likely collapse long before all of the iron had oxidized to provide moderator displacement. As indicated in Section 6.4, only half of the iron in stainless steel $\left(295 \mathrm{~kg} \mathrm{Fe}_{2} \mathrm{O}_{3}\right)$ can be accounted for in a severely degraded configuration because of this potential segregation mechanism.

If carbon steel were used for basket fabrication, then about $85 \%$ of the iron could be accounted for because it experiences general corrosion as discussed in Section 6.4. In addition, approximately $30 \%$ more iron would be available in the same volume of basket material. Therefore, for severely degraded configurations, carbon steel (uncoated, or zinc, nickel, or chromium plated) offers advantages over stainless steel. Note that with no credit for iron, approximately $0.5 \mathrm{~kg}$ of $\mathrm{Gd}$ is required to remain mixed with the degraded fuel in the canister.

Table 6.5.1.1-3. Degraded MIT SNF Homogenized with Iron Oxide and Gat

\begin{tabular}{|l|c|c|c|c|c|}
\hline Case Name & $\begin{array}{c}\text { Mass Fe } \\
\text { Oxide, } \mathrm{kg}\end{array}$ & $\begin{array}{c}\text { Mass Gd, } \\
\mathrm{kg}\end{array}$ & $\mathrm{H}^{235} \mathrm{U}$ & $\begin{array}{c}\text { AENCF*, } \\
\mathrm{MeV}\end{array}$ & $\mathrm{k}_{\text {eff }} \pm 2 \sigma$ \\
\hline mithomi & 767.66 & 0.00 & 103 & 0.0172 & $0.9307 \pm 0.0019$ \\
\hline mithomf & 590.51 & 0.10 & 145 & 0.0159 & $0.9395 \pm 0.0020$ \\
\hline mithomg & 590.51 & 0.12 & 145 & 0.0159 & $0.9178 \pm 0.0020$ \\
\hline mithom1 & 295.25 & 0.00 & 190 & 0.0116 & $1.2265 \pm 0.0024$ \\
\hline mithomb & 295.25 & 0.15 & 190 & 0.0141 & $0.9933 \pm 0.0022$ \\
\hline mithom4 & 295.25 & 0.25 & 190 & 0.0157 & $0.8964 \pm 0.0022$ \\
\hline mithom3 & 295.25 & 0.50 & 190 & 0.0190 & $0.7379 \pm 0.0020$ \\
\hline mithom2 & 295.25 & 1.00 & 190 & 0.0236 & $0.5791 \pm 0.0014$ \\
\hline mithom5 & 0.0 & 0.0 & 235 & 0.0090 & $1.4689 \pm 0.0025$ \\
\hline mithom6 & 0.0 & 0.25 & 235 & 0.0137 & $1.0043 \pm 0.0022$ \\
\hline mithom0 & 0.0 & 0.50 & 235 & 0.0164 & $0.7942 \pm 0.0027$ \\
\hline
\end{tabular}

*AENCF - Average Energy Of Neutron Causing Fission.

With half the iron as oxide, $0.25 \mathrm{~kg}$ of Gd is sufficient and with all the iron as oxide accounted 


\section{Evaluation of Codisposal Viability for Aluminum-Clad DOE-Owned Spent Fuel: Phase II - Degraded Codisposal Waste Package Internal Criticality}

for, only about $0.11 \mathrm{~kg}$ of $\mathrm{Gd}$ must remain. If carbon steel is used for the basket material (767.66 $\mathrm{kg} \mathrm{Fe} \mathrm{O}_{3}$ ), almost all of the Gd could be removed.

Three check cases were run to demonstrate that the homogeneous model is conservative, as listed in Table 6.5.1.1-4. These cases correspond to case mithom 4 in Table 6.5.1.1-3 with the modifications indicated. Note that all three cases are equivalent to (within $95 \%$ confidence interval) or are less reactive than the base model.

Table 6.5.1.1-4. Check Cases - Degraded MIT SNF Homogenized with Iron Oxide and Gd

\begin{tabular}{||c|c|c|c|c|}
\hline Case Name & Case Descriptions & $\mathrm{H}^{235} \mathrm{U}$ & $\begin{array}{c}\mathrm{AENCF} \\
\mathrm{MeV}\end{array}$ & $\mathrm{k}_{\text {eff }} \pm 2 \sigma$ \\
\hline mithom7 & $\begin{array}{c}1 \mathrm{~cm} \text { thick degraded } \\
\text { canister shell }\end{array}$ & 190 & 0.0157 & $0.8982 \pm 0.0024$ \\
\hline mithom8 & $\begin{array}{c}80 \% \text { Fill of the Canister } \\
\text { Total mass of components } \\
\text { maintained }\end{array}$ & 132 & 0.0198 & $0.8825 \pm 0.0025$ \\
\hline mithom9 & $\begin{array}{c}\text { MIT SNF Canister } \\
\text { Centered in Waste Package }\end{array}$ & 190 & 0.0158 & $0.8948 \pm 0.0023$ \\
\hline
\end{tabular}

*AENCF - Average Energy Of Neutron Causing Fission.

For a degraded stainless steel basket, credit can be taken for $0.500 \mathrm{~kg}$ of $\mathrm{Gd}$ and $295 \mathrm{~kg} \mathrm{of} \mathrm{Fe}_{2} \mathrm{O}_{3}$ mixed with the degraded fuel. For a degraded carbon steel basket, credit can be taken for 1.0625 $\mathrm{kg}$ of $\mathrm{Gd}$ and $650 \mathrm{~kg}$ of $\mathrm{Fe}_{2} \mathrm{O}_{3}$ mixed with the degraded fuel. The results in Table 6.5.1.1-3 indicate that a degraded stainless steel basket with a $\mathrm{GdPO}_{4}$ absorber (50\% loss of $\mathrm{Gd}$ and $\mathrm{Fe}$ ) will have twice the Gd inventory required to meet criticality criteria. For a degraded carbon steel basket with $\mathrm{GdPO}_{4}$ absorber ( $15 \%$ loss of $\mathrm{Gd}$ and $\mathrm{Fe}$ ), more than 10 times the required $\mathrm{Gd}$ inventory will be present.

A variation of the degraded SNF and basket configuration would be accumulation of $\mathrm{U}$ and $\mathrm{Al}$ oxides as particulates accumulated at the bottom of the canister with the fragments of undegraded basket steel. The most severe case of settling which might be possible is for a MIT-SNF canister with a carbon steel basket (reference 34, Table 7.4-2). In this case, a maximum of $78 \%$ of the degraded fuel ( $\mathrm{U}$ and $\mathrm{Al}$ oxides) and a minimum of $14 \%$ of the undegraded basket (with Gd) may collect in a layer at the bottom of the canister, with the degradation products of the remaining portions of the basket and fuel in an upper layer. To evaluate this configuration, two cases were run with the steel fragments and particulates distributed over 18 and 24 percent of the canister volume. The corresponding water volume fractions to fill out these canister volume percents are of 0.1 and 0.3 , respectively. "Gd was not included in the cases. The bottom layer composition is homogenized $\mathrm{U}$ and $\mathrm{Al}$ oxides, iron fragments, and water. The results for these cases in the first two rows of Table 6.5.1.1-5 demonstrate that the settled configurations are all well below 0.93 , even without considering the effect of the Gd trapped in the undegraded portions of the basket. They also show that $\mathrm{k}_{\text {eff }}$ is lowered with further settling. To evaluate the more realistic effect of having some of the basket oxides distributed in the bottom layer as opposed to all in the upper layer, a final case was run. In this case, the height of the bottom layer was fixed at $12.5 \mathrm{~cm}(25 \%$ 


\section{Evaluation of Codisposal Viability for Aluminum-Clad DOE-Owned Spent Fuel: Phase II - Degraded Codisposal Waste Package Internal Criticality}

Table 6.5.1.1-5. Degraded MIT SNF and Undegraded Basket Pieces Homogenized and Settled to Bottom of DOE-SNF Canister

\begin{tabular}{|c|c|c|c|c|c|c|}
\hline $\begin{array}{c}\text { Case } \\
\text { Name }\end{array}$ & $\begin{array}{c}\text { Bottom Layer } \\
\text { Water } \\
\text { Fraction }\end{array}$ & $\begin{array}{c}\text { Height of Bottom } \\
\text { Layer }(\mathrm{cm}) \\
\text { [\% of Can Volume] }\end{array}$ & $\begin{array}{c}\text { Bottom } \\
\text { Layer } \\
\mathrm{H}^{235} \mathrm{U}\end{array}$ & $\begin{array}{c}\text { Top } \\
\text { Layer } \\
\mathrm{H}^{235} \mathrm{U}\end{array}$ & $\begin{array}{c}\text { AENCF* } \\
(\mathrm{MeV})\end{array}$ & $\mathrm{k}_{\text {eff }} \pm 2$ \\
\hline mitcol2 & 0.1 & $10.2[18 \%]$ & 6.83 & 475.73 & 0.0417 & $0.6989 \pm 0.0020$ \\
\hline mitcol1 & 0.3 & $12.2[24 \%]$ & 26.34 & 406.56 & 0.0366 & $0.8335 \pm 0.0023$ \\
\hline mitcol4 & $0.32 * *$ & $12.5[25 \%]$ & 13.45 & 499.94 & 0.0362 & $0.7304 \pm 0.0018$ \\
\hline
\end{tabular}

*AENCF - Average Energy Of Neutron Causing Fission.

** Water/U, Al, Fe Oxide Mixture

of the canister volume). As indicated above, the iron fragments and particulates were distributed in this volume, but this time the remaining degradation products were homogenized throughout the canister. The results indicate that the presence of the basket degradation products further reduces $\mathrm{k}_{\text {eff }}$ in the settled configuration.

\subsubsection{Degraded MIT SNF on Top of Degraded HLW}

This model consists of a layer of hydrated oxides representing the degraded remnants of the DOE SNF canister and contents above a volume of clayey material from the degradation of $\mathrm{HLW}$ glass. This model is shown in Figure 6.5-3. This configuration is based on the degradation of the DOE SNF canister while resting on the surface of the clayey material. This configuration is judged unlikely, but was investigated in order for the most reactive configuration to be identified.

Cases were first run to identify the optimum moderator conditions with the full uranium loading $(35.2 \mathrm{~kg})$ and the results are provided in Table 6.5.1.2-1. The maximum $\mathrm{k}_{\mathrm{eff}}$ is observed for the water fraction of 0.83 (solids density of $17 \%$ ).

Table 6.5.1.2-1. Stratified Layers with Degraded MIT Fuel on Top

\begin{tabular}{|c|c|c|c|c|c|}
\hline $\begin{array}{c}\text { Case } \\
\text { Name }\end{array}$ & $\begin{array}{c}\text { Water } \\
\text { Fraction }\end{array}$ & $\begin{array}{c}\text { Fuel Slab } \\
\text { Thickness, cm }\end{array}$ & $\mathrm{H}^{235} \mathrm{U}$ & $\begin{array}{c}\text { AENCF*, } \\
\mathrm{MeV}\end{array}$ & $\mathrm{k}_{\text {eff }} \pm 2 \sigma$ \\
\hline mit081 & 0.81 & 27.4765 & 675 & 0.0040 & $1.1581 \pm 0.0022$ \\
\hline mit082 & 0.82 & 27.4765 & 721 & 0.0038 & $1.1610 \pm 0.0017$ \\
\hline mit083 & 0.83 & 27.4765 & 773 & 0.0038 & $1.1617 \pm 0.0023$ \\
\hline mit084 & 0.84 & 27.4765 & 831 & 0.0036 & $1.1568 \pm 0.0019$ \\
\hline
\end{tabular}

*AENCF - Average Energy Of Neutron Causing Fission. 
Evaluation of Codisposal Viability for Aluminum-Clad DOE-Owned Spent Fuel: Phase II - Degraded Codisposal Waste Package Internal Criticality

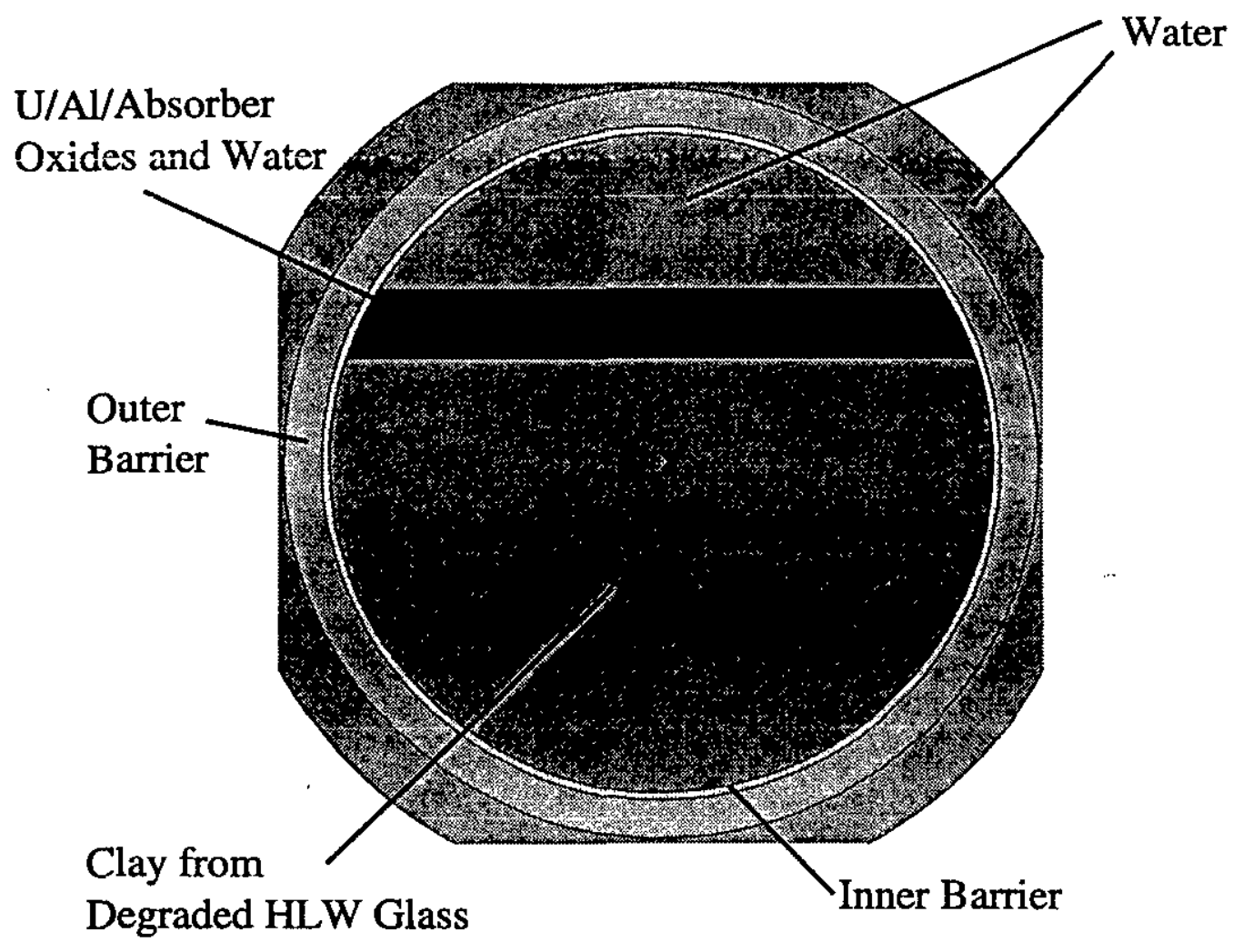

Figure 6.5-3. Degraded MIT SNF on Top of Degraded HLW

Reduced volumes at this optimum moderator condition were also investigated to identify the minimum mass of $U$ ( $93.5 \%$ enriched) which could be critical under these conditions. $2.89 \mathrm{~kg}$ of $U$ has a $k_{\text {eff }}$ of $0.9287 \pm 0.0024$.

Cases were run with various masses of $\mathrm{Gd}$ and $\mathrm{Fe}_{2} \mathrm{O}_{3}$ as indicated in Table 6.5.1.2-2. As indicated previously, about $300 \mathrm{~kg}$ of $\mathrm{Fe}_{2} \mathrm{O}_{3}$ corresponds to a stainless steel basket, and about 600 $\mathrm{kg}$ to a carbon steel basket. Amounts in excess of $590.5 \mathrm{~kg} \mathrm{Fe}_{2} \mathrm{O}_{3}$ are obtained by assuming that part of the XM-19 fuel canister wall is also degraded. In order to achieve $900 \mathrm{~kg} \mathrm{Fe}_{2} \mathrm{O}_{3}$, approximately $80 \%$ of XM-19 has to degrade with a stainless steel basket. However, if the stainless steel is replaced by carbon steel, $35 \%$ degradation in XM-19 would account for $900 \mathrm{~kg}$ $\mathrm{Fe}_{2} \mathrm{O}_{3}$.

Additional cases were run to determine the effects of reducing the uranium loading in the fuel layer. For a $75 \% \mathrm{U}$ loading $(26.4 \mathrm{~kg}$ ), the configuration is subcritical with $60 \mathrm{~g}$ of $\mathrm{Gd}$ with no credit for $\mathrm{Fe}_{2} \mathrm{O}_{3}$ or with $25 \mathrm{~g}$ of $\mathrm{Gd}$ with $295 \mathrm{~kg}$ of $\mathrm{Fe}_{2} \mathrm{O}_{3}$ (reference 46, Tables 7.3.1.2-6, -7, -8). For a $50 \% \mathrm{U}$ loading, the configuration is subcritical even without credit for $\mathrm{Gd}$ or $\mathrm{Fe}_{2} \mathrm{O}_{3}$ (reference 46, Table 7.3.1.2-9). 
Evaluation of Codisposal Viability for Aluminum-Clad DOE-Owned Spent Fuel: Phase II - Degraded Codisposal Waste Package Internal Criticality

Table 6.5.1.2-2. Stratified Layers with Degraded MIT Fuel on Top with Different $\mathrm{Fe}_{2} \mathrm{O}_{3}$ and Gd Loadings

\begin{tabular}{|c|c|c|c|c|c|c|}
\hline $\begin{array}{c}\text { Case } \\
\text { Name }\end{array}$ & $\begin{array}{c}\text { Mass of } \\
\mathrm{Fe}_{2} \mathrm{O}_{3}, \mathrm{~kg}\end{array}$ & $\begin{array}{c}\text { Mass of } \\
\mathrm{Gd}, \mathrm{kg}\end{array}$ & $\begin{array}{c}\text { Fuel Slab } \\
\text { Thickness, cm }\end{array}$ & $\mathrm{H} / \mathrm{I}^{235} \mathrm{U}$ & $\begin{array}{c}\text { AENCF*, } \\
\text { MeV }\end{array}$ & $\mathrm{k}_{\text {eff }} \pm 2 \sigma$ \\
\hline mitt10 & 0 & 0.10 & 21.4 & 633 & 0.0049 & $0.9792 \pm 0.0020$ \\
\hline mitt20 & 0 & 0.20 & 21.4 & 633 & 0.0056 & $0.8566 \pm 0.0021$ \\
\hline mitf10 & 300 & 0.10 & 28.1 & 810 & 0.0043 & $0.9388 \pm 0.0019$ \\
\hline mitf20 & 300 & 0.20 & 28.1 & 810 & 0.0049 & $0.8265 \pm 0.0018$ \\
\hline mitfe6k & 600 & 0.0 & 35.7 & 993 & 0.0035 & $1.0155 \pm 0.0016$ \\
\hline mitf6g5 & 600 & 0.050 & 35.7 & 993 & 0.0038 & $0.9333 \pm 0.0008$ \\
\hline mitf6g6 & 600 & 0.060 & 35.7 & 993 & 0.0038 & $0.9166 \pm 0.0009$ \\
\hline Mitfe9k & 900 & 0.0 & 44.5 & 1174 & 0.0031 & $0.9460 \pm 0.0014$ \\
\hline Mitf9g1 & 900 & 0.010 & 44.5 & 1174 & 0.0034 & $0.9277 \pm 0.0009$ \\
\hline
\end{tabular}

*AENCF - Average Energy Of Neutron Causing Fission.

For a degraded stainless steel basket, credit can be taken for $0.500 \mathrm{~kg}$ of Gd and $295 \mathrm{~kg} \mathrm{of} \mathrm{Fe}_{2} \mathrm{O}_{3}$ mixed with the degraded fuel. For a degraded carbon steel basket, credit can be taken for 1.0625 $\mathrm{kg}$ of $\mathrm{Gd}$ and $650 \mathrm{~kg}$ of $\mathrm{Fe}_{2} \mathrm{O}_{3}$ mixed with the degraded fuel. The results in Table 6.5.1.2-2 indicate that a degraded stainless steel basket with a $\mathrm{GdPO}_{4}$ absorber (50\% loss of $\mathrm{Gd}$ and $\mathrm{Fe}$ ) will have 4 times the $\mathrm{Gd}$ inventory required to meet criticality criteria. For a degraded carbon steel basket with $\mathrm{GdPO}_{4}$ absorber ( $15 \%$ loss of $\mathrm{Gd}$ and $\mathrm{Fe}$ ), more than 17 times the required $\mathrm{Gd}$ inventory will be present. For a degraded carbon steel basket with $\mathrm{GdPO}_{4}$ absorber $(15 \%$ loss of $\mathrm{Gd}$ and $\mathrm{Fe}$ ) and credit for the $\mathrm{Fe}_{2} \mathrm{O}_{3}$ from the DOE SNF canister, more than 100 times the required $\mathrm{Gd}$ inventory will be present 


\section{Evaluation of Codisposal Viability for Aluminum-Clad DOE-Owned Spent Fuel: Phase II - Degraded Codisposal Waste Package Internal Criticality}

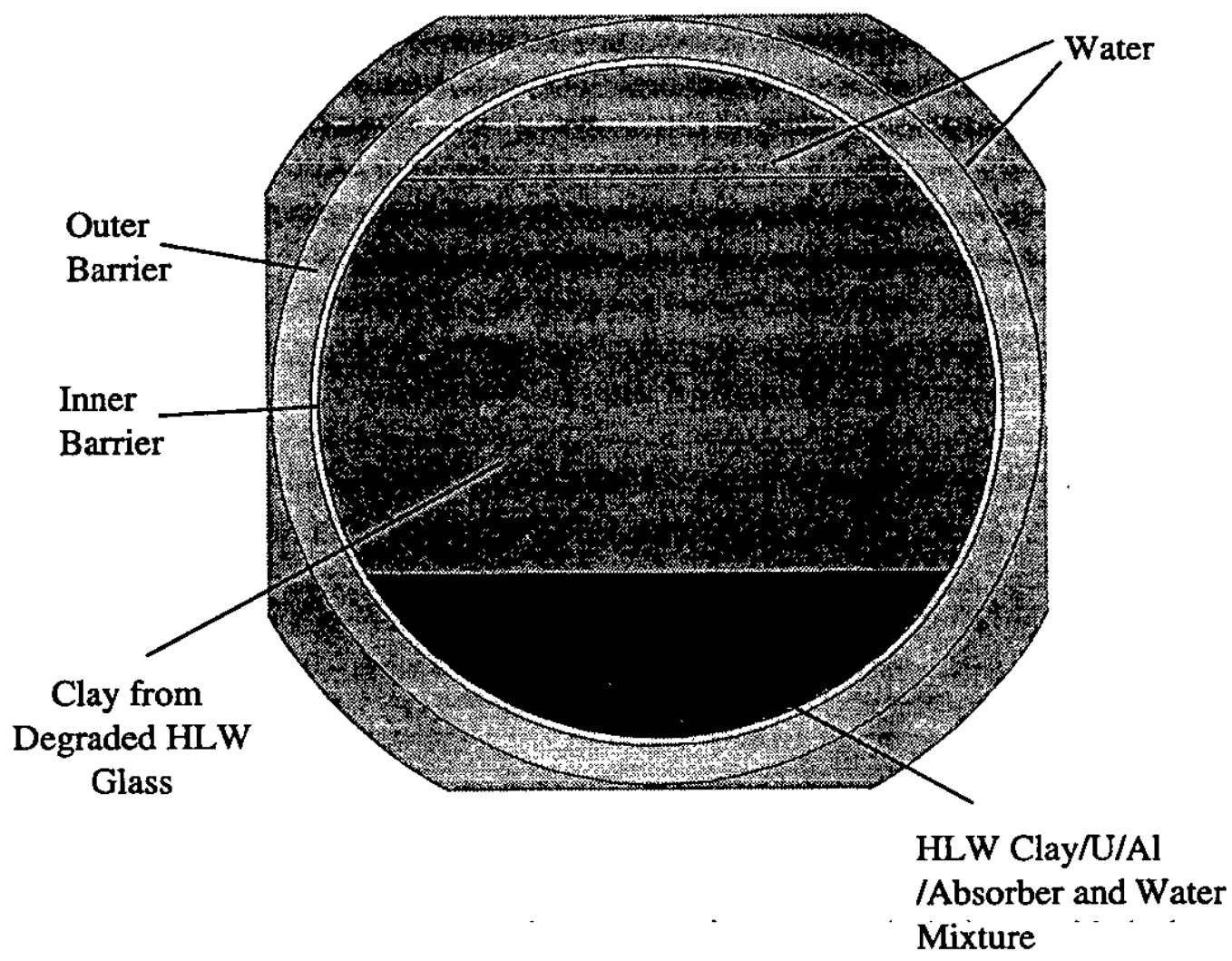

Figure 6.5-4. Degraded MIT SNF Mixed With Degraded HLW

\subsubsection{Degraded MIT SNF Mixed With Degraded HLW}

This model consists of various fractions of the HLW clayey material mixed with the degraded DOE SNF accumulated starting in a canister-sized volume below the unmixed fraction of HLW and proceeding until the DOE SNF is mixed with the HLW clayey material in the layer just covering the canister. This configuration is shown in Figure 6.5-4. This configuration is based on the degradation of the DOE SNF canister surrounded by the HLW clayey material. As the DOE SNF canister degrades, there will be some mixing of the HLW clayey material and the degraded MIT fuel forms. The water fraction is kept consistent in the bottom fuel/clay mixture and the HLW clayey material on the top. It is not credible to have a less dense mixture at the bottom. The water fraction and the amount of the HLW clayey material mixed with the degraded MIT fuel form are the two parameters varied in this configuration.

The fraction of clay into which degraded fuel was mixed was varied along with the water fraction in the clay to determine the most reactive composition for the full $U$ loading without credit for 


\section{Evaluation of Codisposal Viability for Aluminum-Clad DOE-Owned Spent Fuel: Phase II - Degraded Codisposal Waste Package Internal Criticality}

$\mathrm{Fe}_{2} \mathrm{O}_{3}$ or $\mathrm{Gd}$. The admixed clay fraction was varied from $0 \%$ (thin layer of degraded DOE SNF on bottom without clay) to $100 \%$ (homogeneous mixture of clay and degraded fuel). The water fraction was varied from 0.15 to 0.272 which corresponds to filling the waste package completely with degradation products and water. The peak $\mathrm{k}_{\text {eff }}$ was found for a $15 \%$ clay mix and a water fraction of 0.272 . The cases necessary to identify this peak are listed in Table 6.5.1.3-1. The homogeneous mixture of all the clay and degraded fuel was identified to be subcritical without credit for any $\mathrm{Fe}_{2} \mathrm{O}_{3}$ or $\mathrm{Gd}$. Note that the fragments of stainless steel or the $\mathrm{Fe}_{2} \mathrm{O}_{3}$ likely present from the degradation of the HLW canisters are not accounted for in these calculations.

Table 6.5.1.3-1. Clay Mixed With Degraded MIT Fuel

\begin{tabular}{|c|c|c|c|c|c|}
\hline Case Name & $\begin{array}{c}\text { Percent } \\
\text { Clay }\end{array}$ & $\begin{array}{c}\text { Water } \\
\text { Fraction }\end{array}$ & $\mathrm{H}^{235} \mathrm{U}$ & $\begin{array}{c}\text { AENCF*, } \\
\mathrm{MeV}\end{array}$ & $\mathrm{k}_{\text {eff }} \pm 2 \sigma$ \\
\hline mitb520 & 10 & 0.20 & 160 & 0.012 & $0.9454 \pm 0.0029$ \\
\hline mitb525 & 10 & 0.25 & 206 & 0.0097 & $1.0170 \pm 0.0030$ \\
\hline mitb620 & 15 & 0.20 & 220 & 0.0089 & $0.9671 \pm 0.0027$ \\
\hline mitb625 & 15 & 0.25 & 283 & 0.0077 & $1.0262 \pm 0.0025$ \\
\hline mitb627 & 15 & 0.272 & 313 & 0.0070 & $1.0464 \pm 0.0025$ \\
\hline mitb720 & 20 & 0.20 & 280 & 0.0076 & $0.9727 \pm 0.0027$ \\
\hline mitb725 & 20 & 0.25 & 359 & 0.0064 & $1.0177 \pm 0.0025$ \\
\hline
\end{tabular}

*AENCF - Average Energy Of Neutron Causing Fission.

Cases were run with various masses of $\mathrm{Gd}$ and $\mathrm{Fe}_{2} \mathrm{O}_{3}$ as indicated in Table 6.5.1.3-2 for the most reactive mix. These cases were run to provide an indication of the margin for the likely configuration. The presence of the $\mathrm{Gd}$ or $\mathrm{Fe}_{2} \mathrm{O}_{3}$ could cause minor shifts in the water fraction or clay percent that is most reactive for a given mixture. These minor variations would have no effect on the conclusions drawn from these results.

Table 6.5.1.3-2. Stratified Layers with Degraded MIT Fuel Mixed with $15 \%$ of HLW Glass Clay at bottom with Different $\mathrm{Gd}$ and $\mathrm{Fe}_{2} \mathrm{O}_{3}$ Loadings

\begin{tabular}{|l|c|c|c|c|c|}
\hline $\begin{array}{l}\text { Case } \\
\text { Name }\end{array}$ & $\begin{array}{c}\text { Gd Mass, } \\
\mathrm{kg}\end{array}$ & $\begin{array}{c}\mathrm{Fe}_{2} \mathrm{O}_{3} \text { Mass, } \\
\mathrm{Kg}\end{array}$ & $\mathrm{H}^{235} \mathrm{U}$ & $\begin{array}{c}\text { AENCF*, } \\
\mathrm{MeV}\end{array}$ & $\mathrm{k}_{\text {eff }} \pm 2 \sigma$ \\
\hline mitxgd5 & 0.05 & 0 & 313 & 0.0078 & $0.9621 \pm 0.0025$ \\
\hline mitxgd1 & 0.10 & 0 & 313 & 0.0082 & $0.8959 \pm 0.0025$ \\
\hline mitxfg2 & 0.02 & 295 & 312 & 0.0075 & $0.9537 \pm 0.0022$ \\
\hline mitxfg4 & 0.04 & 295 & 312 & 0.0077 & $0.9257 \pm 0.0023$ \\
\hline mitxfgx & 0.00 & 590.5 & 312 & 0.0077 & $0.9257 \pm 0.0023$ \\
\hline
\end{tabular}

*AENCF - Average Energy Of Neutron Causing Fission. 


\section{Evaluation of Codisposal Viability for Aluminum-Clad DOE-Owned Spent Fuel: Phase II - Degraded Codisposal Waste Package Internal Criticality}

Additional cases were run to determine the effects of reducing the uranium loading in the fuel layer. For a $75 \% \mathrm{U}$ loading $(26.4 \mathrm{~kg}$ ), the configuration is subcritical with $20 \mathrm{~g}$ of $\mathrm{Gd}$ with no credit for $\mathrm{Fe}_{2} \mathrm{O}_{3}$ or with no $\mathrm{Gd}$ with $295 \mathrm{~kg}$ of $\mathrm{Fe}_{2} \mathrm{O}_{3}$ (reference 46, Tables 7.3.1.3-11, -12, -13). For a 50\% U loading, the configuration is subcritical even without credit for $\mathrm{Gd}$ or $\mathrm{Fe}_{2} \mathrm{O}_{3}$ (reference 46, Table 7.3.1.3-14).

For a degraded stainless steel basket, credit can be taken for $0.500 \mathrm{~kg}$ of $\mathrm{Gd}$ and $295 \mathrm{~kg} \mathrm{of} \mathrm{Fe}_{2} \mathrm{O}_{3}$ mixed with the degraded fuel. For a degraded carbon steel basket, credit can be taken for 1.0625 $\mathrm{kg}$ of $\mathrm{Gd}$ and $650 \mathrm{~kg}$ of $\mathrm{Fe}_{2} \mathrm{O}_{3}$ mixed with the degraded fuel. The results in Table 6.5.1.3-2 | indicate that a degraded stainless steel basket with a $\mathrm{GdPO}_{4}$ absorber ( $50 \%$ loss of $\mathrm{Gd}$ and $\mathrm{Fe}$ ) will have 12.5 times the $\mathrm{Gd}$ inventory required to meet criticality criteria. For a degraded carbon steel basket with greater than $590.5 \mathrm{~kg} \mathrm{Fe}_{2} \mathrm{O}_{3}$, no $\mathrm{Gd}$ is required for the configuration to be subcritical. Obviously, with credit for the $\mathrm{Fe}_{2} \mathrm{O}_{3}$ from the DOE SNF canister, no Gd is required with either a carbon steel or stainless steel basket.

\subsubsection{Degraded ORR SNF Criticality Analysis}

\subsubsection{Homogeneous Mixture of Degraded ORR SNF in DOE SNF Canister}

A description and illustration of this configuration is provided in Section 6.5.1.1.

As indicated in Section 4.1.3, the ORR canister basket does not include borated stainless steel absorber plates. The phase I analysis (reference 2, Table 6.5.1.2-3) showed that borated stainless steel between-layer plates were required to keep the configuration subcritical with degraded fuel and intact baskets. Based on the results for a carbon steel basket in a MIT SNF canister, a carbon steel basket was analyzed in an ORR SNF canister where the ORR fuel is homogenized with water and uniformly distributed throughout the basket cell. In addition to changing the basket material from Type 316 stainless steel to A516 carbon steel, the ORR fuel was also more realistically degraded to a mixture of soddyite $\left(\left[\mathrm{UO}_{2}\right]_{2}\left[\mathrm{SiO}_{4}\right] \cdot 2 \mathrm{H}_{2} \mathrm{O}\right), \mathrm{Al}_{2} \mathrm{O}_{3}, \mathrm{SiO}_{2}$, and water, rather than just homogenizing it throughout the cell as was done in the Phase I analysis (reference 2 ). The results of the criticality evaluation indicate that the $\mathrm{k}_{\mathrm{eff}}$ in this degraded configuration is $0.8861 \pm 0.0030$ (MCNP case "orroz4a"; AENCF $=0.0249 \mathrm{MeV}$ ), thus demonstrating the viability of the carbon steel basket option in the intact configuration.

The degraded fuel and basket configuration was analyzed providing the results shown in Table 6.5.2.1-1. The boron from the between-layer (axial) separator plates was assumed flushed out of the DOE SNF canister and was not considered (Assumption 4.3.3). Amounts of $\mathrm{Fe}_{2} \mathrm{O}_{3}$ corresponding to that available from $50 \%(163.3 \mathrm{~kg})$ and $100 \%(326.6 \mathrm{~kg})$ of the stainless steel basket material were homogenized into the degraded ORR/water mixture. As with the MIT analysis, the DOE SNF canister is modeled at the bottom of the mass of degraded HLW glass clayey material to maximize neutron reflection into the DOE SNF canister. The HLW clayey material is modeled with $25 \%$ free water fraction, and nearly fills the waste package. If carbon steel were used in the basket then up to $490 \mathrm{~kg}$ of $\mathrm{Fe}_{2} \mathrm{O}_{3}$ could be produced with credit being taken for about $417 \mathrm{~kg}$ ( $85 \%$ credit). A total of $380 \mathrm{~kg}$ of oxide would be sufficient to reduce $\mathrm{k}_{\text {eff }}$ below 0.93 . 
Evaluation of Codisposal Viability for Aluminum-Clad DOE-Owned Spent Fuel: Phase II - Degraded Codisposal Waste Package Internal Criticality

Table 6.5.2.1-1. Degraded ORR Fuel Homogenized In DOE SNF Canister with Iron Oxide From Degraded Basket (No Boron Remaining; Canister Surrounded by Clay)

\begin{tabular}{|c|c|c|c|c|c|c|}
\hline Case Name & $\begin{array}{c}\text { Mass of } \mathrm{Fe}_{2} \mathrm{O}_{3} \\
\text { Remaining from } \\
\text { Basket, kg }\end{array}$ & $\begin{array}{c}\text { Mass of } \\
\mathrm{Gd}, \mathrm{kg}\end{array}$ & $\begin{array}{c}\text { Water } \\
\text { Fraction }\end{array}$ & $\mathrm{H}^{235} \mathrm{U}$ & $\begin{array}{c}\mathrm{AENCF} \\
\mathrm{MeV}\end{array}$ & $\mathrm{k}_{\text {eff }} \pm 2 \sigma$ \\
\hline orrhom3 & 163 & 0 & 0.7058 & 535.8 & 0.01242 & $1.0440 \pm 0.0022$ \\
\hline orrhom2 & 327 & 0 & 0.6272 & 477.2 & 0.01379 & $0.9521 \pm 0.0022$ \\
\hline orrhom6 & 380 & 0 & 0.6015 & 458.0 & 0.01428 & $0.9262 \pm 0.0021$ \\
\hline orrhom1 & 490 & 0 & 0.5486 & 418.6 & 0.01539 & $0.8673 \pm 0.0023$ \\
\hline orrhom4 & 163 & 0.25 & 0.7058 & 535.8 & 0.02292 & $0.5513 \pm 0.0015$ \\
\hline orrhom5 & 163 & 0.1 & 0.7058 & 535.8 & 0.01660 & $0.7550 \pm 0.0020$ \\
\hline orrhom7 & 0 & 0.1 & 0.7844 & 594.4 & 0.01563 & $0.8060 \pm 0.0022$ \\
\hline
\end{tabular}

*AENCF - Average Energy Of Neutron Causing Fission.

\subsubsection{Degraded ORR SNF on Top of Degraded HLW}

This scenario is based on the HLW canister degrading before the codisposal canister and is described and illustrated in Section 6.5.1.2. The degraded ORR fuel will then form a layer on top of the clay if the DOE SNF canister rests on the surface of the degrading HLW canisters and glass. Criticality calculations were performed for this degraded configuration, with various water fractions in the degraded ORR layer, and above the layer for configurations which do not completely fill the waste package. For conservatism, no $\mathrm{Fe}_{2} \mathrm{O}_{3}$ from degradation of the canisters or the ORR basket has been included. The degraded HLW clay at the bottom of the waste package is modeled with no free water. The results are provided in Table 6.5.2.2-1 and indicate that the $\mathrm{k}_{\text {eff }}$ for this configuration is well | below 0.93 for all amounts of water content, and, therefore, does not present a criticality concern.

Table 6.5.2.2-1. Layer of Degraded ORR Fuel on Top of Degraded HLW Glass Clayey Material

\begin{tabular}{|c|c|c|c|c|c|}
\hline $\begin{array}{c}\text { Case } \\
\text { Name }\end{array}$ & $\begin{array}{c}\text { ORR Water } \\
\text { Fraction }\end{array}$ & $\begin{array}{c}\text { Fuel Slab } \\
\text { Thickness, cm }\end{array}$ & $\begin{array}{c}\mathrm{H}^{235} \mathrm{U} \\
\text { Ratio }\end{array}$ & $\begin{array}{c}\text { AENCF** } \\
\mathrm{MeV}\end{array}$ & $\mathrm{k}_{\text {eff }} \pm 2 \sigma$ \\
\hline orr080 & 0.8 & 8.7 & 652.5 & 0.01079 & $0.7526 \pm 0.0025$ \\
\hline orr085 & 0.85 & 11.8 & 920.4 & 0.00841 & $0.8018 \pm 0.0020$ \\
\hline orr090 & 0.9 & 18.0 & 1456.1 & 0.00622 & $0.8172 \pm 0.0019$ \\
\hline
\end{tabular}

*AENCF - Average Energy Of Neutron Causing Fission.

\subsubsection{Degraded ORR SNF Mixed With Degraded HLW}

| This scenario is described and illustrated in Section 6.5.1.3. To evaluate this scenario, criticality calculations have been performed for various mixtures of degraded ORR fuel and HLW clay at the bottom of the waste package, with various water fractions in both the mixed and unmixed layers (same fraction in both layers). For conservatism, no $\mathrm{Fe}_{2} \mathrm{O}_{3}$ from degradation of the canisters or the ORR basket has been included. As with the previous cases, the region above the clayey material 


\section{Evaluation of Codisposal Viability for Aluminum-Clad DOE-Owned Spent Fuel: Phase II - Degraded Codisposal Waste Package Internal Criticality}

(in cases where the clay does not completely fill the waste package) and outside of the waste package is modeled as being filled with water to conservatively maximize neutron reflection. The results are provided in Table 6.5.2.3-1 and indicate that this configuration is well below $\mathrm{k}_{\text {eff }}$ of 0.93 for all water contents and combinations of HLW clay and ORR mix, and, therefore, does not present a criticality concern.

Table 6.5.2.3-1. Degraded ORR Fuel at the Bottom of Waste Package Mixed With Various Amounts of Clay From Degraded HLW Glass

\begin{tabular}{|c|c|c|c|c|c|}
\hline Case Name & $\begin{array}{c}\text { Fraction of } \\
\text { Clay Mixed } \\
\text { with ORR }\end{array}$ & $\begin{array}{c}\text { Clay and } \\
\text { ORR/Clay } \\
\text { Water } \\
\text { Fraction }\end{array}$ & $\begin{array}{c}\mathrm{H}^{235} \mathrm{U} \\
\text { Ratio }\end{array}$ & $\begin{array}{c}\text { AENCF* } \\
(\mathrm{MeV})\end{array}$ & $\mathrm{k}_{\text {eff }} \pm 2 \sigma$ \\
\hline ob10v20 & 0.10 & 0.200 & 334.5 & 0.01802 & $0.6671 \pm 0.0021$ \\
\hline ob15v20 & 0.15 & 0.200 & 476.9 & 0.01441 & $0.6706 \pm 0.0023$ \\
\hline ob20v20 & 0.20 & 0.200 & 619.2 & 0.01197 & $0.6553 \pm 0.0020$ \\
\hline ob25v20 & 0.25 & 0.200 & 761.6 & 0.01056 & $0.6343 \pm 0.0018$ \\
\hline ob25v25 & 0.25 & 0.250 & 970.6 & 0.00922 & $0.6549 \pm 0.0019$ \\
\hline ob25v29 & 0.25 & 0.289 & 1155.4 & 0.00786 & $0.6611 \pm 0.0017$ \\
\hline
\end{tabular}

*AENCF - Average Energy Of Neutron Causing Fission.

The configuration with the degraded ORR fuel homogeneously mixed with $100 \%$ of the degraded HLW clayey material is subcritical with all moderator fractions (reference 46, Table 7.3.2.2-2).

\subsection{Uncertain Parameters and Sensitivity}

The sensitivity to uncertainties in the flow paths of water dripping into the waste package has already been discussed in Section 6.4.3 for boron, and Section 6.4.4.1 for Gd. The following uncertainties relate to frequently raised issues. In our present state of knowledge, they cannot be treated quantitatively.

- The geochemical analyses used a 10 year lifetime for the uranium aluminide fuel (MIT DOE SNF), based on previous studies discussed in reference 34. However, recent experimental data (unreported) suggests it might be as long as 1000 years. Such a long lifetime would decrease the chance that most of the SNF would degrade while there was still a high $\mathrm{pH}$ solution from the ongoing degradation of the HLW glass. Hence there would be much less chance of the uranium removal scenario. However, without overwhelming probability of that scenario, it must be found to be too non-conservative, and it has not been considered in the conclusions or recommendations (guidance) provided by this report.

- The long-term drip rate may be even less than the lowest used in this report $(0.1 \mathrm{~mm} / \mathrm{yr})$. Such low drip rate would extend the time for removal of $\mathrm{Gd}$ in the unfavorable circumstance of no available phosphate, thereby increasing the time to earliest criticality beyond the 60,000 years estimated discussed in Section 6.3.4.1. 


\section{Evaluation of Codisposal Viability for Aluminum-Clad DOE-Owned Spent Fuel: Phase II - Degraded Codisposal Waste Package Internal Criticality}

- It has been conjectured, based on some hydrologic models of Yucca Mountain, that episodic flows of up to $20 \mathrm{~m}^{3}$ onto a single waste package could occur within a one week time period (CDA Assumption TDSS 026). Since this volume is much larger than the WP volume $\left(4.5 \mathrm{~m}^{3}\right)$, most of the water will also flow out of the WP flushing out dissolved material if any reasonable circulation exists within the WP. If such a deluge occurred after a slow dripping had degraded the criticality control material, but not necessarily removed it from the waste package, it could provide both the mechanism for removal of a soluble neutron absorber and the moderator which enables criticality. The probability of such a deluge has not been quantified because the frequency of such a deluge is completely unknown. At expected drip rates $(<10 \mathrm{~mm} / \mathrm{yr})$, at least 100 years would be required to fill the WP, and complete flushing of all dissolved material would likely require an order of magnitude longer time period, depending upon circulation. The methodology for using the geochemistry code, EQ3/6, considers the balance among the transport and reaction processes. Results presented in this report are all based upon the conservative assumption of complete circulation during a filling period.

- As discussed in reference 34, the mechanism for acidification of waste package water, e.g., the complete oxidation of chromium to the chromate ion which produces chromic acid, is theoretically possible, but has not been observed experimentally. It is this uncertainty which makes the effectiveness of $\mathrm{Gd}_{2} \mathrm{O}_{3}$ questionable.

- The results of this study are not very sensitive to the differential settling evaluated in Section 6.4.2. Table 6.4-2 shows that the worst case separation between uranium and a gadolinium neutron absorber could be viewed in two ways: (1) having $78 \%$ of the uranium in a layer on the bottom of the DOE SNF canister with only $14 \%$ of the gadolinium for criticality control (carbon steel case), or (2) having $100 \%$ of the uranium distributed throughout the canister (since the table only gives a maximum for uranium at the bottom, the minimum could be zero leaving $100 \%$ for distribution throughout the canister) with only $55 \%$ of the gadolinium remaining because $45 \%$ had settled to the bottom (stainless steel case). Both these cases have been bounded by the evaluations in Section 6.5 , and found to be subcritical with a margin in Gd mass of at least a factor of two. Therefore, there is little sensitivity to this uncertainty in differential settling.

- The uncertainties in the EQ6 calculations stem mainly from uncertainty in the reaction rates for the various material aqueous degradation processes. These reaction rates are hard to measure because they are very slow and because their effects can be easily confounded by the lack of solubility of the reaction products. To compensate for such uncertainties, most of the calculations were based on conservative estimates of these parameters, i.e., values which would lead to configurations more likely to have the potential for criticality. For example, runs were made for different infiltration rates and different potentialities to separate neutron absorbers from fissile material. Although uncertainties also exist in the thermodynamic data, these data have been much more thoroughly reviewed and selected and seem to introduce less uncertainty than do the data for reaction rates. The uncertainties in the results of EQ6 are described in further detail in reference 25 , Section 7.5. 


\section{Evaluation of Codisposal Viability for Aluminum-Clad DOE-Owned Spent Fuel:}

Phase II - Degraded Codisposal Waste Package Internal Criticality

\subsection{Probability of Criticality: Comparison of Alternatives}

This analysis is concerned with the occurrence of configurations which may be critical, and not with the actual occurrence of criticality per se. Nevertheless, the results of the calculations of configurations can be used, together with probabilities of water drip and water retention (for moderation), to compare probability of criticality for the three alternative criticality control materials (Assumption 4.3.16). This comparison is given in Table 6.7-1 for criticality occurrence during a 60,000 year period, most likely near the end of the period. The first line of this table gives the conditional probabilities for the occurrence of a geometry and geochemistry which removes the neutron absorber which was calculated in Sections 6.4.3 and 6.4.4.1 for the first two columns. For purposes of illustration, the time period covered by these probabilities is taken to be 40,000 to 60,000 years. As explained in Section 6.4.3, for times greater than 8600 years, the conditional probability of boron loss, given the required dripping and collection of water in the DOE SNF canister, is conservatively estimated as 1 . For $\mathrm{Gd}_{2} \mathrm{O}_{3}$, however, the 60,000 years coincides with the shortest time to achieve low $\mathrm{pH}$ and high Gd solubility, as given by the analysis in Section 6.4.4.1, and the probability that the low $\mathrm{pH}$ solution will contact the gadolinium remains as calculated in that section. The conditional probability of zero in the third column $\left(\mathrm{GdPO}_{4}\right)$ reflects the analysis summarized in Section 6.4.4.2, and would hold for upwards of several hundred thousand years. The second line of Table 6.7-1 is an adaptation of probability calculations made in reference 47 . The items in the third line are the products of the first two lines. The details of the calculation of the second line are given in Attachment $\mathrm{V}$ of reference 34.

Table 6.7-1. Probabilities (per waste package) of the Occurrence of Potentially Critical Configurations for Alternative Criticality Control Materials

\begin{tabular}{|l|l|l|l|}
\hline Description of System Element & \multicolumn{3}{|c|}{ Alternative Criticality Control Material } \\
\cline { 2 - 4 } & Boron & $\mathrm{Gd}_{2} \mathrm{O}_{3}$ & $\mathrm{GdPO}_{4}$ \\
\hline $\begin{array}{l}\text { Conditional probability of a geometry and } \\
\text { geochemistry which removes the indicated } \\
\text { neutron absorber (given the required drip rate) }\end{array}$ & 1.0 & 0.0725 & 0 \\
\hline $\begin{array}{l}\text { Probability of required drip rate (on any given } \\
\text { package) and retention of sufficient water for } \\
\text { moderator (same for all alternatives) }\end{array}$ & 0.007 & 0.007 & 0.007 \\
\hline Combined probability of criticality & $7 \times 10^{-3}$ & $5.08 \times 10^{-4}$ & 0 \\
\hline
\end{tabular}

These are very conservative estimates and should be used for comparison of alternatives only. 


\section{Evaluation of Codisposal Viability for Aluminum-Clad DOE-Owned Spent Fuel: Phase II - Degraded Codisposal Waste Package Internal Criticality}

\section{Conclusions}

As identified in Sections 2.0, 4.0, and 5.1, this analysis is based on unqualified/unconfirmed input data and nonvalidated software, thus any data or conclusions from this report used for input into CRWMS documents supporting construction, fabrication, or procurement are required to be controlled and tracked as TBV or TBD in accordance with NLP-3-15, To Be Verified (TBV) and To Be Determined (TBD) Monitoring System, or other appropriate procedures.

\subsection{Analysis Results}

The criticality analyses performed show that the highly enriched MIT fuel can be disposed of within a DOE-SNF canister in the codisposal waste package, provided that certain criticality control measures are implemented. Similarly, a DOE-SNF canister containing moderately enriched ORR fuel can also be disposed of within the codisposal waste package provided that the canisters contain a carbon steel basket with borated stainless steel separator plates between layers. Evaluations of the neutronic behavior of the degraded fuel materials outside the codisposal waste package will be performed as part of Phase III analyses.

This analysis examined the degradation scenarios for the DOE-SNF canister and the HLW glass canisters and performed geochemistry and criticality analyses for the range of potential configurations which could occur inside of the waste package. The criticality analyses indicate that an insoluble neutron absorber material is needed to maintain criticality control for several of the degraded configurations evaluated for the HEU (MTT) aluminum based fuel type. Without the presence of an insoluble neutron absorber, the long-term action of infiltrating water can lead to a small, but significant, probability of postclosure criticality for the HEU SNF.

Note that some conclusions are based on very unlikely physical processes. Further refinement of the degradation scenarios may lead to relaxation of some criticality control requirements. However, it is expected that some amount of $\mathrm{Gd}$ will be required in the canisters.

- The boron in borated stainless steel, initially used as the neutron absorber for the intact configuration, has the potential to be lost as the canister degrades. Preliminary corrosion testing indicates that the borides in the stainless steel matrix have a corrosion rate similar to that of the matrix, and are expected to degrade to a soluble form shortly after they are released from the stainless steel. The resulting boric acid is likely to be transported out of the waste package during the degradation process (Assumption 4.3.3). Borated carbon steel does exist and might perform better with respect to criticality, but no analysis has yet been performed for this material.

- The degradation rate assumed for $\mathrm{Al}, \mathrm{U}-\mathrm{Al}$, and $\mathrm{U}-\mathrm{Al}-\mathrm{Si}$, does not have a significant impact on the configurations or compositions formed as long as these materials degrade before or in the same time frame as the basket materials. If the U-Al and U-Al-Si degrade much slower than the basket structure, then the settled configuration within the DOE-SNF canister is more probable and results in a less reactive configuration (Section 6.5.1.1).

- If the DOE SNF canister is breached while the HLW glass is still degrading, it is likely that 


\section{Evaluation of Codisposal Viability for Aluminum-Clad DOE-Owned Spent Fuel: Phase II - Degraded Codisposal Waste Package Internal Criticality}

the highly alkaline solution from the degrading HLW may dissolve a significant fraction of the uranium released by the degraded SNF. This dissolved uranium may be flushed from the waste package, thereby precluding the possibility of internal criticality (Section 6.3.2).

- High pH could be beneficial for criticality control but credit cannot be taken for it in a licensing analysis because the conditions for occurrence of a high $\mathrm{pH}$ are uncertain and nonconservative.

- The criticality analyses have demonstrated that the degraded configurations can meet the criticality control requirements for long-term disposal if the borated stainless steel is replaced with insoluble $\mathrm{Gd}$ phosphate (Section 6.5). Gadolinium phosphate appears to be insoluble over the entire range of $\mathrm{pH}$ possible in the waste package and in the DOE SNF canister (Section 6.3.4.2).

- The small difference in density between the uranium-containing particulates and the gadolinium-containing particulates in the degraded waste package will not result in significant stratification. This conclusion is based on a theoretical analysis using the range of possible settling velocities and on a review of the literature on the stratification in natural placer deposits (Section 6.4.2).

- With the progressive degradation of the basket of the DOE SNF canister, some of the steel and gadolinium can settle to the bottom in intact fragments of steel, but only while a significant fraction of the basket remain̄s intāt. The geometric hindrance of the remaining basket will limit the amount of gadolinium contained in the carbon steel that can sett'e by this mechanism to less than $14 \%$ of the total gadolinium in the carbon steel basket or $45 \%$ of the total gadolinium in a stainless steel basket (Section 6.4.4.2).

- The intact basket configurations with degraded fuel were shown to be limiting in regards to requirements for $\mathrm{Gd}$ mass to be subcritical. For the MIT canister containing $35.2 \mathrm{~kg}$ of $93.5 \%$ enriched uranium in the intact basket configuration, approximately $1 \mathrm{~kg}$ of Gd is required to be distributed in the basket in the locations originally designated for borated stainless steel if the basket is constructed of stainless steel and $1.25 \mathrm{~kg}$ of Gd is required if the basket is constructed of carbon steel. Lesser amounts of $\mathrm{Gd}$ were required to maintain criticality control in the degraded configurations (Section 6.5).

- Utilization of carbon steel for basket fabrication is also shown to have advantages over the use of stainless steel by maximizing the water displacement potential of the iron oxide resulting from degradation of the basket and maximizing the mixing of the fuel with the iron oxide from the degraded basket (Section 6.5). Because of the higher yield strength of carbon steel compared to stainless steel, carbon steel would also be superior from a structural perspective (Section 6.3.7).

- The results for degraded MIT SNF and basket materials within the canister indicate that a degraded stainless steel basket with a $\mathrm{GdPO}_{4}$ absorber will have twice the Gd inventory required to meet criticality criteria. For a degraded carbon steel basket with $\mathrm{GdPO}_{4}$ absorber, 


\section{Evaluation of Codisposal Viability for Aluminum-Clad DOE-Owned Spent Fuel: Phase $I$ - Degraded Codisposal Waste Package Internal Criticality}

more than 10 times the required $\mathrm{Gd}$ inventory will be present (Section 6.5.1.1).

- The results for the configuration involving a layer of degraded SNF above the degraded HLW indicate that a degraded stainless steel basket with a $\mathrm{GdPO}_{4}$ absorber will have 4 times the $\mathrm{Gd}$ inventory required to meet criticality criteria. For a degraded carbon steel basket with $\mathrm{GdPO}_{4}$ absorber, more than 17 times the required $\mathrm{Gd}$ inventory will be present. For a degraded carbon steel basket with $\mathrm{GdPO}_{4}$ absorber and credit for the $\mathrm{Fe}_{2} \mathrm{O}_{3}$ from the XM-19 DOE-SNF canister shell, more than 100 times the required Gd inventory will be present (Section 6.5.1.2).

- The results for the configuration with a mix of clayey material from degraded HLW and degraded MIT SNF indicate that a degraded stainless steel basket with a GdPO absorber ( $50 \%$ loss of $\mathrm{Gd}$ and $\mathrm{Fe}$ ) will have 12.5 times the $\mathrm{Gd}$ inventory required to meet criticality criteria. For a degraded carbon steel basket with greater than $590.5 \mathrm{~kg} \mathrm{Fe} 2 \mathrm{O}_{3}, 0 \mathrm{~kg} \mathrm{Gd}$ is required for the configuration to be subcritical. Obviously, with credit for the $\mathrm{Fe}_{2} \mathrm{O}_{3}$ from the XM-19 DOE-SNF canister shell, $0 \mathrm{~kg} \mathrm{Gd}$ is required with either a carbon steel or stainless steel basket (Section 6.5.1.3).

- The results for the configuration with degraded ORR SNF in an intact basket indicate that a carbon steel basket plus borated stainless steel meet the criticality criteria (6.5.2.1).

- The results for the configuration with degraded ORR SNF and a degraded basket indicate that the iron oxide from a carbon steel basket provides sufficient water displacement and absorption to keep the configuration subcritical without additional absorbers. A de jraded stainless steel basket would require about $0.10 \mathrm{~kg}$ of $\mathrm{Gd}$ to keep the configuration subcritical (Section 6.5.2.1).

- All degraded configurations involving degraded ORR fuel outside the DOE-SNF canister and in, above, or below the clay formed from the degradation of the HLW glass were below the threshold of concern for criticality, even without credit for $\mathrm{Gd}$ or iron oxide (Sections 6.5.2.2 and 6.5.2.3).

\subsection{Guidance for the Codisposal Canister Design}

The results of this study provide the following guidance to the designer and fabricator of the codisposal canisters for the MIT and ORR SNF, and for other DOE aluminum clad fuels having characteristics within the same envelope

- The $\mathrm{k}_{\text {eff }}$ must be less than 0.95 after allowance for bias and uncertainty (ANSI/ANS-8.17) for both intact and degraded configurations.

- A dispersed insoluble neutron absorber material must be utilized in the basket unless the insoluble degradation products from the basket can be demonstrated to provide sufficient water displacement and/or neutron absorption to prevent criticality within the canister.

- Carbon steel is preferred over stainless steel for the basket material, in order to minimize the presence of chromium (which may produce acidic conditions when oxidized); carbon 
Evaluation of Codisposal Viability for Aluminum-Clad DOE-Owned Spent Fuel: Phase II - Degraded Codisposal Waste Package Internal Criticality

steel also maximizes the water displacement potential of iron oxide and increases the mixing potential of the fuel with the degraded basket and neutron absorber materials.

- The neutron absorber and the degradation products from the basket must be insoluble over the pH range of 5 to 11 .

- Gadolinium is preferred over boron, as the neutron absorber for criticality control, because it is much less soluble over the expected range of $\mathrm{pH}$ values.

- The selection of a Gd criticality control material should consider that Gd-phosphate is preferred over Gd-oxide because it is less soluble, particularly in the mildly acidic regime which could result from the corrosion of stainless steel (see Section 6.5).

\subsection{Future Plans}

The degradation of aluminum clad fuel can result in the redistribution of uranium materials from the original location within the codisposal canister to areas outside the waste package. The potential of a critical event occurring due to fuel relocation outside the waste package will be evaluated in Phase III. 
Evaluation of Codisposal Viability for Aluminum-Clad DOE-Owned Spent Fuel: Phase II - Degraded Codisposal Waste Package Internal Criticality

\section{References}

1 Data Package from Savannah River Criticality Analysis of MIT \& ORR SNF, (including Appendix A data for MIT \& ORR fuel, drawings R3F-3-2, R3F-1-4, M-11495-OR-001, M-11495-OR-003, and M-11495-OR-004), Records Batch \# MOY-970021-01, Civilian Radioactive Waste Management System (CRWMS) Management and Operating Contractor (M\&O), 1997.

2 Evaluation of Codisposal Viability for Aluminum-Clad DOE-Owned Spent Fuel: Phase I Intact Codisposal Canister, Document Identifier Number (DI\#): BBA000000-01717-570500011 REV 01, CRWMS M\&O.

3 Classification of the Preliminary MGDS Repository Design, DI\#: B00000000-01717-020000134 REV 00, CRWMS M\&O.

4 QAP-2-O Activity Evaluations, ID No. WP-30, Perform Criticality, Thermal, Structural, and Shielding Analyses as Required for DOE Spent Fuel Characterization, Dated 8/3/97, CRWMS M\&O.

5 Quality Assurance Requirements and Description, DOE/RW-0333P REV 7, DOE Office of Civilian Radioactive Waste Management (OCRWM).

| 6 Technical Document Preparation Plan For The Evaluation of Codisposal Viability for DOE-Owned Research Reactor Spent Fuel Reports, DI\#: BBA000000-01717-460000010 REV 01, CRWMS M\&O.

7 EQ3/6 Software Test and Verification Report 9/94, LLYMY09602100, Records Package Number: MOL.19960417.0194, 02/16/96.

8 Nuclear Criticality Safety Guide, LA12808, Los Alamos National Laboratory.

19 Software Qualification Report for MCNP4A, DI\#: 30006-2003 REV 02, CRWMS M\&O.

10 Waste Package Materials Selection Analysis, DI\#: BBA000000-01717-0200-00020 REV 01, CRWMS M\&O.

11 Characteristics of Potential Repository Wastes, DOE/RW-0184-R1; Volume 1, U.S. DOE OCRWM.

12 Characteristics of Potential Repository Wastes, DOE/RW-0184-R1; Volume 1, U.S. DOE OCRWM.

13 Harrar, J. E., Carley, J. F., Isherwood, W. F., and Raber, E., Report of the Committee to Review the Use of J-13 Well Water in Nevada Nuclear Waste Storage Investigations, UCID21867, 1990, Lawrence Livermore National Laboratory, Livermore, CA. 
Evaluation of Codisposal Viability for Aluminum-Clad DOE-Owned Spent Fuel: Phase II - Degraded Codisposal Waste Package Internal Criticality

14 Waste Package Degradation Expert Elicitation Panel: Input on the Corrosion of CRM Alloy C-22, EMCR Update Draft for VA: Activity ID\# WP20AM4, MOL-199804061118, CRWMS M\&O.

15 Criticality Evaluation of Degraded Internal Configurations for the PWR AUCF WP Designs, DI\#: BBA000000-01717-0200-00056 REV 00, CRWMS M\&O.

16 Total System Performance Assessment - 1995: An Evaluation of the Potential Yucca Mountain Repository, DI\#: B00000000-01717-2200-000136 REV 01, CRWMS M\&O.

17 Bates, J., Strachan, D., Ellison, A., Buck, E., Bibler, N., McGrail, B. P., Bourcier, W., Grambow, B., Sylvester, K., Wenzel, K., and Simonson, S., Glass Corrosion and Irradiation Damage Performance, Plutonium Stabilization \& Immobilization Workshop, December 11-14, 1995, Washington, D. C.

18 Bates, J., Strachan, D., Ellison, A., Buck, E., Bibler, N., McGrail, B. P., Bourcier, W., Grambow, B., Sylvester, K., Wenzel, K., and Simonson, S., Glass Corrosion and Irradiation Damage Performance, Plutonium Stabilization \& Immobilization Workshop, December 11-14, 1995, Washington, D. C.

19 Engineered Barrier Design Requirements Document, YMP/CM-0024, REV 0, ICN 1, Yucca Mountain Site Characterization Project.

20 Controlled Design Assumptions Document, DI\#: B0000000-01717-4600-00032 REV 04 ICN 03, CRWMS M\&O.

21 10CFR60; Disposal of High-Level Radioactive Wastes in Geologic Repositories, U.S. Nuclear Regulatory Commission, Federal Register, Volume 61, Number 234, pp. 6425764270, January 3, 1997.

22 Report of the U.S. Department of Energy Environmental Management Criticality Safety Workshop, February 24-26, 1997, National Spent Nuclear Fuel Program, INEL/EXT-9700543, Idaho National Engineering Laboratory/U. S. Department of Energy Office of Environmental Management, May 1997.

23 Criticality Abstraction/Testing.Workshop Results, DI\#: B00000000-01717-2200-00187 REV 00, CRWMS M\&O.

24 Criticality Abstraction/Testing Workshop Results, DI\#: B00000000-01717-2200-00187 REV 00, CRWMS M\&O.

25 Immersion Studies on Candidate Container Alloys for the Tuff Repository, 1991, Nuclear Regulatory Commission, NUREG/CR-5598. 
Evaluation of Codisposal Viability for Aluminum-Clad DOE-Owned Spent Fuel: Phase II - Degraded Codisposal Waste Package Internal Criticality

26 Roy, A. J., Fleming, D. L., and Lum, B. Y., Stress Corrosion Cracking of Fe-Ni-Cr-Mo, $\mathrm{Ni}$-Cr-Mo and Ti Alloys in 90 C Acidic Brine, UCRL-JC-128477, Lawrence Livermore National Laboratory, 1997.

27 Criticality Safety and Shielding Evaluations of the Codisposal Canister in the Five-Pack DHLW Waste Package, DI\#: BBA000000-01717-0200-00052 REV 01, CRWMS M\&O.

28 BWR Assembly Source Terms for Waste Package Design, DI\#; BBA000000-017170200-00024 REV 00, CRWMS. M\&O.

29 International Handbook of Evaluated Criticality Safety Benchmark Experiments, NEA/NSC/DOC(95)03/, Volume II.b, Nuclear Energy Agency, Organization for Economic Co-operation and Development, November 4, 1996 update.

30 Criticality Safety and Shielding Evaluation of the Codisposal Canister in the Five-Pack DHLW Waste Package, DI\#: BBA000000-01717-0200-00052 REV 01, CRWMS M\&O.

31 MCNP Evaluation of Laboratory Critical Experiments: Homogeneous Mixture Criticals, DI\#: BBA000000-01717-0200-00045 REV 00, CRWMS M\&O.

32 Wolery, Thomas J., EQ3/6, A Software Package for Geochemical Modeling of Aqueous Systems: Package Overview and Installation Guide (Version 7.0), UCRL-MA-110662 PT I, Lawrence Livermore National Laboratory, 1992.

Software Qualification Report for MCNP Version 4B2, CSCI:30033 V4BLV, DI\#: 300332003 REV 00, CRWMS M\&O.

34 Geochemical and Physical Analysis of Degradation Modes of $H E U$ in a Codisposal Waste Package with HLW Canisters, DI\#: BBA000000-01717-0200-00059 REV 01, CRWMS M\&O (TBV).

35 Busenberg, E., The Products of the Interaction of Feldspars with Aqueous Solutions at $25^{\circ} \mathrm{C}$, Geochimica et Cosmochimica Acta, Vol. 42, 1978, pp. 1679-1686.

$36 \mathrm{Gd}_{2} \mathrm{O}_{3}$ Neutron Absorber Plates Specifications, Docket Number 71-9239, Appendix I-6, October, 1996.

37 Palache, C., Berman, H., and Frondel, C., The System of Mineralogy, 7th ed., vol. II, 1951, John Wiley \& Sons, Inc. Mechanical Engineers, 1995.

39 Standard Specification for Pressure Vessel Plates, Carbon Steel, for Moderate-andLower-Temperature Service, ASTM A516/A516M-90, American Society for Testing and 
Evaluation of Codisposal Viability for Aluminum-Clad DOE-Owned Spent Fuel: Phase II - Degraded Codisposal Waste Package Internal Criticality

Materials, Philadelphia, PA.

40 Evaluation of Codisposal Viability for Aluminum-Clad DOE-Owned Spent Fuel: Phase I Intact Codisposal Canister, DI\#: BBA000000-01717-5705-00011 REV 01, CRWMS M\&O.

41 Gaudin, A. M., Principles of Mineral Dressing, 1939, McGraw-Hill Book, Co.

42 Wills, B. A., Mineral Processing Technology, 4th ed., 1988, Pergamon Press.

| 43 Weast, R. C., ed., CRC Handbook of Chemistry and Physics, 58th Ed., 1977, CRC Press, Inc., Cleveland, OH.

| 44 Roberts, W. L., Jr., Rapp, G. R., Jr., and Weber, J., Encyclopedia of Minerals, 1974, van Nostrand Reinhold Co.

45 Robbins, John A., Sediments of Southern Lake Huron: Elemental Composition and Accumulation Rates, Environmental Research Laboratory, Duluth Office of Research and Development, U. S. Environmental Protection Agency, EPA-600/3-80-080, 1980.

46 Disposal Criticality Analysis for Aluminum-based Fuel in a Codisposal Waste Package ORR and MIT SNF - Phase II, DI\#: BBA000000-01717-0200-00060 REV 00, CRWMS $\mathrm{M} \& \mathrm{O}$. REV 01, CRWMS M\&O. 
References $\bigotimes$ in Public Literature $\square$ Routing Concurrently [.]Journal Article Journal Name

Book/Book Chapter Book Name $\square$ Conference Submission*

$\square$ Abstract $\square$ Conf. Paper $\square$ Conf. Proceeding

$\square$ Slides/poster/display $\square$ Other

*Conference Title

*Conference Location (City, State, Country)

*Conference Dates $\mathrm{m} / \mathrm{d} / \mathrm{y}$ thru $\mathrm{m} / \mathrm{d} / \mathrm{y}$

*Conference Sponsor

\Approved for Release

$X$ Other NOT OSTE-RERORTABE

I understand that for the information in this material to be given external distribution, approvals by both WSRC and, as appropriate, DOE-SR are required. Distribution (verbally or published) must be in accordance with policies set forth in WSRC management requirements and procedures (MRP 3.25 ) and in DOE-SR orders, and the content of the external distributionmust be limited to that actually approved.

$3 / 1 / 99$ Date

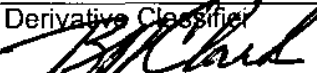

Intênded Distribution

Docume-nt requested

by INEL for

Xunlimited (release to public)

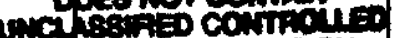

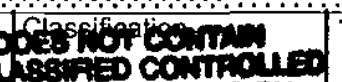

$\therefore$ Site Use Only

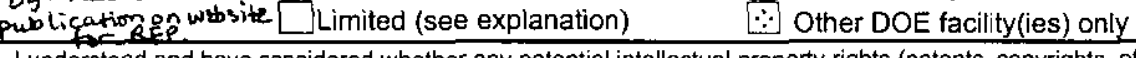

$I$ understand and have considered whether any potential intellectual property righte-(patents, copyrights, etc., in accordance with MP 1.09 and MRP 1.07) or

any contractural barriers (CRADAs, Work for Others, etc.) may be involved before authgrizing that this document be proposed for public release. If any

concerns were idegtified, these have been discussed and resolved with General Counse R.M. Serague

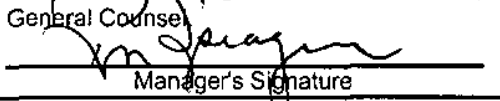

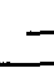
Manager's Sifnature

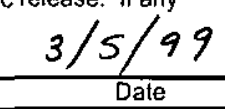

$\because$ Corporate/University Partner

$\because$ Corporat
Approval Requested by (date)

RAND $3 / 9 / 99$

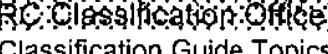

3/30/99 RCND 3/9/99

$\square$ Yes $\square$ No If yes, date submitted

"Conference Dates _Conference Sponsor

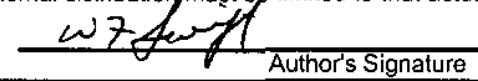

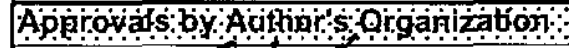

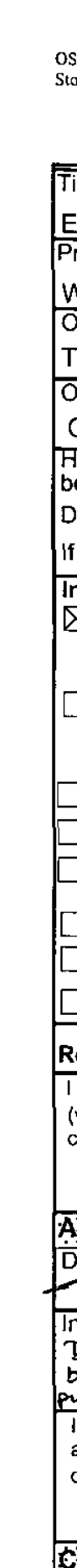

$$
\text { ingticto }
$$
(1)

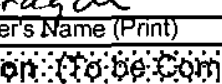

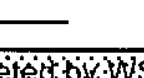

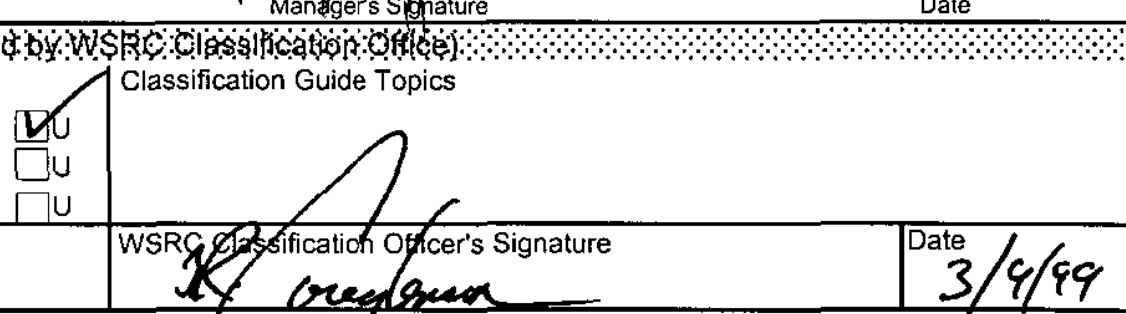

Title

$\square$ UCNI UCN1

Officer's Name (Print) Aficer's Name (P)

nive:

Signature

\begin{tabular}{|l|l|l}
\hline Phone No. & Position & User ID \\
$7-6302$ & TSF/Alt. Tech. & O5531 \\
\hline
\end{tabular}

9

\section{BBA000000-01717-5705-00017 REV 01}

\section{列 \\ .}

. 
March 9, 1999

BBA000000-01717-5705-0001

MSD-STI-97-4126

Ms. W. F. Perrin, Technical Information Officer

U. S. Department of Energy - Savannah River Operations Office

Dear Ms. Perrin:

\section{REQUEST FOR APPROVAL TO RELEASE SCIENTIFIC/TECHNICAL INFORMATION}

The attached document is submitted for classification and technical approvals for the purpose of external release. Please complete Part II of this letter and return the letter to the undersigned by 3/30/99. The document has been reviewed for classification and export control by a WSRC

Classification staff member and has been determined to be Unclassified.

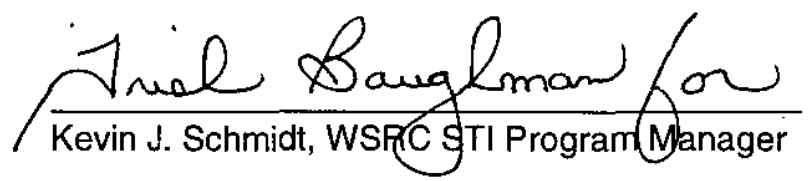

\section{DETAILS OF REQUEST FOR RELEASE}

Document Number: BBA000000-01717-5705-00

Author's Name: W. Swift

Location: 707-C

Phone 7-6302

Department: Deputy Manager \& Technical Programs

Document Title: Evaluation of Codisposal Viability for Aluminum-Clad DOE-Owned Spent

Fuel: Phase II - Degraded Codisposal Waste Package Internal Criticality

Presentation/Publication:

Meeting/Journal:

$$
\text { Location: } \quad N / A
$$
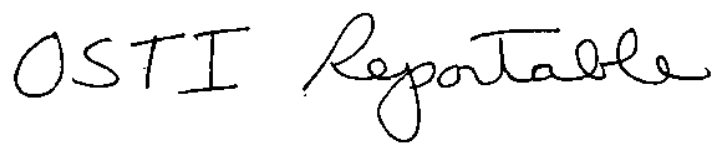

\section{DOE-SR ACTION}

Date Received by TIO $03 / 10 / 99$

$\square$ Approved for Release

[X] Approved Upon Completion of Changes

Approved with Remarks

Not Approved

Revise and Resubmit to DOE-SR

Remarks: See changes attached
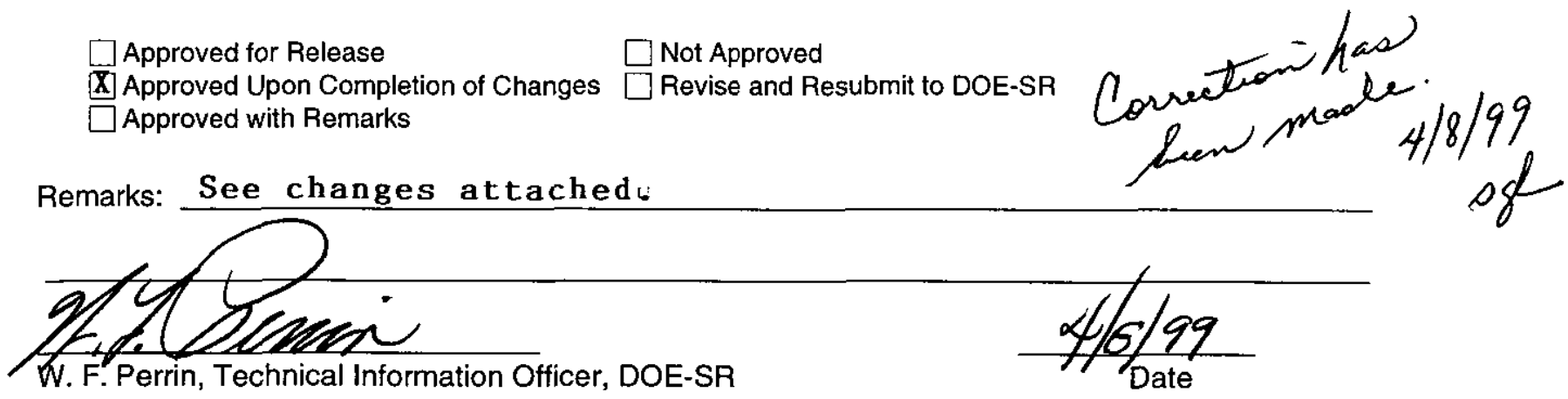
$\rightarrow$ mate

a. .

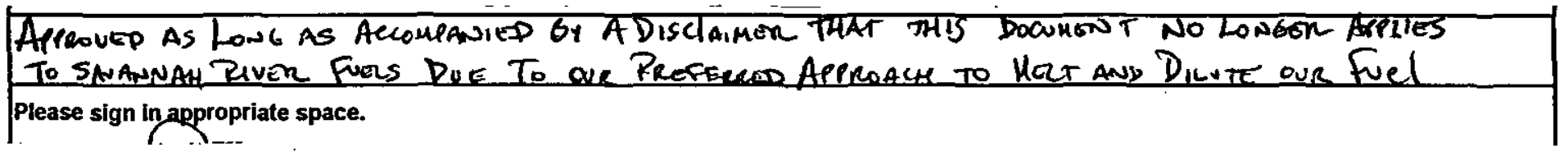




\section{ANNOUNCEMENT OF U. S. DEPARTMENT OF ENERGY (DOE) SCIENTIFIC AND TECHNICAL INFORMATION (STI)}

RECORD STATUS (select one):

X...New ..... Revised Data ....... Kevised STI Product

Part I: STI PRODUCT DESCRIPTION

A. STI PRODUCT TYPE (select one)

X.. 1. Technical Report
a. Type: $\square$ Topical $\square$ Semiannual $\square$ Annual $\triangle$ Final
Other (specify)
b. Reporting Period ( $\mathrm{mm} / \mathrm{dd} / \mathrm{y} y y y$,
thru

...... 2. Conference

a. Product Type: ..... Conference Proceedings ...... Conference Paper or Other (abstracts, excerpts, etc.)

b. Conference Information (title, location, dates)

…. 3. Software Manual ( The actual software package should be made available simultaneously. Follow instructions provided with ESTSC F 1 and ESTSC F 2.)

..... 4. Journal Article
a. Type: $\quad \underline{X}$ Announcement citation only
_ Preprint
_. Postprint
b. Journal Name
e. Serial identifier (e.g., ISSN or CODEN)

c. Volume__ d. Issue

.... 5. S\&T Accomplishment Report

.... 6. Book

.... 7. Patent Application

a. Date Filed $(\mathrm{mm} / \mathrm{dd} / \mathrm{yyyy})$

b. Date Priority $(\mathrm{mm} / \mathrm{dd} / \mathrm{y} y \mathrm{yy})$

c. Patent Assignea

8. Thesis/Dissertation

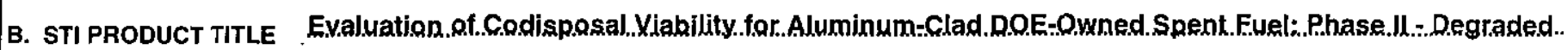

C. AUTHOR(s)
E-mail Address (es):

D. STI PRODUCT IDENTIFIER
1. Report Number(s) BRA0Q0000-0.17.17-57.05-0.0017,
2. DOE Contract Number(s) _DE-AC.09-96\$SR.1.85.00.
3. R\&D Project $I D(s)$
4. Other ldentifying Number(s)

E. ORIGINATING RESEARCH ORGANIZATION Savannah River Site

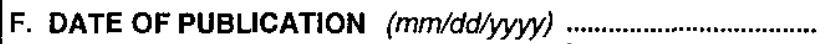

G. LANGUAGE (if non-English) English

(Grantees and Awardees: Skip to Description/Abstract section at the end of Part I)

H. SPONSORING ORGANIZATION

I. PUBLISHER NAME AND LOCATION (if other than research organization)

Availability (refer requests to [if applicable])

J. SUBJECT CATEGORIES (iist primary one first) $\quad 0.5$.

Keywords _Radjoactixe.Waste, Spent.Fuel .Aluminum-Clad, Codispo.sal, Degraded.

K. DESCRIPTION/ABSTRACT

This report presents the analysis and conclusions with respect to disposal criticality for canisters containing aluminum-based fuels from research reactors. 
US DEPARTMENT OF ENERGY

\section{ANNOUNCEMENT OF U. S. DEPARTMENT OF ENERGY (DOE) SCIENTIFIC AND TECHNICAL INFORMATION (STI)}

Part II: STI PRODUCT MEDIAFORMAT and LOCATIONTRAANSMISSION

\section{A. MEDIAFORMAT INFORMATION}

1. Medium of STI product is: $\quad$ X.. Paper $\quad$....... Electronic document $\quad$...... Computer medium $\quad$..... Audiovisual material

2. Size of STI product

3. File format:

a. If electronic document is posted at site, indicate: $\square$ html $\square$ pdfn $\square$ sgml $\square$ xml

b. If electronic document is transmitted to OSTI, indicate: $\square$ html $\square$ pdfn $\square$ pdfi $\square$ msword

_ TIFFG4 __WP-indicate Version (5.0 or greater)

_ MS Word-indicate Version (5.0 or greater)

4. If computer medium or audiovisual material:
a. Quantity/type (specify)
b. Machine compatibility (specity)
f. Other information about product format a user needs to know: Postscript

\section{B. LOCATION/TRANSMISSION INFORMATION}

1. STI Product is available at site: Unique URL (of specific STI Product)

2. STI Product is being transmitted to OSTI:

a._. Electronically via FTP

b. - Via Mail or shipment (e.g., Federal Express) (Paper products, electronic documents on CD-ROM, diskettes, videocassettes, etc.)

3. Information Product Filename (of transmitted electronic formaf)

C. ADDITIONAL INFORMATION (concerning media/format or location/transmission; for OSTI internal use only):

(Grantees and Awardees: Skip to Contact section at the end of Part III)

Part III: STI PRODUCT REVIEW? RELEASE INFORMATION

A. ACCESS LIMITATION

X..... 1. Unlimited Announcement (available to U.S. and non-U.S. public)

........ 2. OpenNet (use OpenNet guidance for below):

a. If additional source other than making it available through NTIS:

(1) Accession Number

(2) Document Location

b. Field Office Acronym

c. Declassification date $(\mathrm{mm} / \mathrm{dd} / \mathrm{yyyy})$

d. Declassification Status:

_Declassified _- Sanitized _ Never classified

3. U.S. Dissemination Only

4. Copyrighted material; Are there any restrictions based on copyright?

e. OpenNet Document Type

f. OpenNet Document Keywords

g. OpenNet Addressee

5. Small Business Innovation Research (SB/R) Release date (mm/dd/yyy)

6. Small Business Technology Transfer (STTR) Release date (mm/dd/yyyy)

7. Proprietary/Trade Secret

8. Patent Pending

9. Protected data CRADA Other (specify) Release date (mm/dd/yyyy)

10. Official Use Only (OUO)

11. Program-Directed Special Handling (specify)

12. Export Controlit AR/EAR

13. Unclassified Controlled Nuclear Information (UCN)

14. Classified Classification Level/Category of:
a. This form $\mathrm{U}$
b. The STI Product Unclassitied

15. Other information relevant to access (specify; for OSTI internal use only))

B. OTHER (information useful to include in published announcement record which is not suited for any other field on this form)

\section{CONTACT AND RELEASING OFFICIAL}

1.Contact (if appropriate, the organization or site contact to include in published citations who would receive any external questions about the content of the STI Product or the research information contained therein)

Name and/or Position

K.J. Schmidt, Manager STI Program \& Site Support

E-mail

Organization Westinghouse Savannah River Company Phone - (803) 725-2321

2. Releasing Official $\mathbf{X}$ I verify that all necessary reviews have been completed (e.g. Patent, Copyright, ECl, UCNI, etc.)

Released by (name) K.J. Schmidt_ Date $(\mathrm{mm} / \mathrm{dd} / \mathrm{yyy} y)$ 